\title{
A 2020 VISION OF SUBSURFACE DRIP IRRIGATION IN THE U.S.
}

Freddie R. Lamm ${ }^{1, *}$, Paul D. Colaizzi², Ronald B. Sorensen ${ }^{3}$, James P. Bordovsky ${ }^{4}$, Mark Dougherty ${ }^{5}$, Kris Balkcom ${ }^{6}$, Daniele Zaccaria ${ }^{7}$, Khaled M. Bali ${ }^{8}$, Daran R. Rudnick ${ }^{9}$, R. Troy Peters ${ }^{10}$

${ }^{1}$ Northwest Research-Extension Center, Kansas State University, Colby, Kansas, USA.

${ }^{2}$ USDA-ARS Conservation and Production Research Laboratory, Bushland, Texas, USA.

${ }^{3}$ USDA-ARS National Peanut Research Laboratory, Dawson, Georgia, USA.

${ }^{4}$ Texas A\&M AgriLife Research, Plainview, Texas, USA.

5 Department of Biosystems Engineering, Auburn University, Auburn, Alabama, USA.

${ }^{6}$ Department of Crop, Soil, and Environmental Sciences, Auburn University, Auburn, Alabama, USA.

7 Department of Land, Air, and Water Resources, University of California-Davis, Davis, California, USA.

${ }^{8}$ Kearney Agricultural Research and Extension Center, University of California-Davis, Parlier, California, USA.

${ }^{9}$ Department of Biological Systems Engineering, University of Nebraska-Lincoln, Lincoln, Nebraska, USA.

${ }^{10}$ Department of Biological Systems Engineering, Washington State University, Prosser, Washington, USA.

*Correspondence: flamm@ksu.edu.

\section{HighLIGHTS}

- Subsurface drip irrigation (SDI) has continued to expand in irrigation area within the U.S. during the last 15 years.

- Research with SDI continues for multiple crop types (fiber, grain and oilseed, horticultural, forage, and turf).

- SDI usage on many crops has matured through research and development of appropriate strategies and technologies

- Despite some persistent challenges to successful use of SDI, important opportunities exist for further adoption.

ABSTRACT. Subsurface drip irrigation (SDI) offers several advantages over alternative irrigation systems when it is designed and installed correctly and when best management practices are adopted. These advantages include the ability to apply water and nutrients directly and efficiently within the crop root zone. Disadvantages of SDI in commercial agriculture relative to alternative irrigation systems include greater capital cost per unit land area (except for small land parcels), unfamiliar management and maintenance protocols that can exacerbate the potential for emitter clogging, the visibility of system attributes (components and design characteristics) and performance, and the susceptibility to damage (i.e., rodents and tillage) of the subsurface driplines. Despite these disadvantages, SDI continues to be adopted in commercial agriculture in the U.S., and research efforts to evaluate and develop SDI systems continue as well. This article summarizes recent progress in research (2010 to 2020) and the status of commercial adoption of SDI, along with a discussion of current challenges and future opportunities.

Keywords. Drip Irrigation, Irrigation, Irrigation systems, Microirrigation, SDI, Water management.

$\mathrm{T}$ he American Society of Agricultural and Biological Engineers (ASABE) defines subsurface drip irrigation (SDI) as the application of irrigation below the soil surface by microirrigation emitters (ASABE, 2019). Although there are many microirrigation systems that are installed at very shallow depths and perform similarly to surface drip irrigation (DI), the focus of this

\footnotetext{
(c) (1) $\Theta$ The authors have paid for open access for this article. This work is licensed under a Creative Commons AttributionNonCommercial-NoDerivatives 4.0 International License https://creative commons.org/licenses/by-nc-nd/4.0/

Submitted for review on 3 March 2021 as manuscript number NRES 14555; approved for publication as an Invited Review Article and as part of the National Irrigation Symposium 2020 Collection by the Natural Resources \& Environmental Systems Community of ASABE on 4 May 2021.

Mention of company or trade names is for description only and does not imply endorsement by the USDA. The USDA is an equal opportunity provider and employer.
}

article is limited to SDI systems that are intended for multiple years of use before replacement. Modern use of SDI in the U.S. began about 60 years ago, and some of the earliest work during that period is attributed to Sterling Davis at the U.S. Salinity Laboratory in Riverside, California (Davis, 1974; Hall, 1985). Early SDI systems were often plagued by emitter clogging, root intrusion, rodent damage, and poor uniformity. A resurgence in interest in the 1980s both in research and commercial practice was reported by Camp et al. (2000), primarily because of better materials and components, as well as development of improved management and maintenance practices.

The status of SDI technology was discussed at the 2000 and 2010 decennial national irrigation symposiums sponsored by ASABE and the Irrigation Association (IA) (Camp et al., 2000; Lamm et al., 2012a) and in a review of four primary SDI crops in the U.S. (cotton, tomato, corn, and onion) at another ASABE/IA symposium in 2015 (Lamm, 2016). 
Table 1. Abbreviations used in the text and tables.

\begin{tabular}{|c|c|}
\hline $\mathrm{CP}$ & Center pivot mechanical move irrigation system \\
\hline DI & Surface drip irrigation \\
\hline DRZ & $\begin{array}{c}\text { Direct root zone (DRZ) irrigation as described } \\
\text { by Jacoby and Ma (2018) }\end{array}$ \\
\hline $\mathrm{EC}$ & Electrical conductivity of soil or water \\
\hline Epan & Pan evaporation \\
\hline ET & Crop evapotranspiration \\
\hline FI & Furrow irrigation (gravity) \\
\hline GHG & Greenhouse gases \\
\hline$K_{c}$ & Crop coefficient to modify reference ET to crop ET \\
\hline MESA & $\begin{array}{l}\text { Mid-elevation spray application for center pivot } \\
\text { and lateral move sprinklers }\end{array}$ \\
\hline $\mathrm{N}$ & Nitrogen \\
\hline NA & Not applicable or not available depending on context \\
\hline NR & Net returns \\
\hline PRD & Partial root zone drying \\
\hline $\mathrm{S}^{3} \mathrm{DI}$ & $\begin{array}{l}\text { Shallow subsurface drip irrigation as described } \\
\text { by Sorensen et al. (2010b) }\end{array}$ \\
\hline SDI & Subsurface drip irrigation \\
\hline SGI & Surface irrigation (gravity) \\
\hline SprI & Sprinkler irrigation \\
\hline WP & Water productivity (crop yield / crop water use) \\
\hline
\end{tabular}

The goal of this review is to augment those earlier articles with a focus on SDI progress in the U.S. during the past ten years (2010 to 2020), and the literature discussed is limited to the U.S. At the end of this article, we discuss the anticipated future of SDI in the U.S. based on the research discussed here and on researchers' knowledge and experience with SDI in their respective regions. For ease of following this article, all abbreviations are summarized in table 1.

\section{GROWTH OF SDI SYSTEMS}

The growth of SDI continues in the U.S. (fig. 1), increasing in land area by $167 \%$ (164,017 to $437,893 \mathrm{ha})$ in the 15-year period between 2003 and 2018 (USDA-NASS, 2004, $2010,2014,2018)$, but is still only $27 \%$ of the total land area of surface drip (DI) and SDI combined (microsprinkler and bubbler irrigation are not included in these estimates).

The bulk of the SDI land area (94\%) is situated in ten U.S. states, but there is wide variation in the ratio of SDI / (SDI + DI) land area (fig. 2). California had by far the largest area in 2018 , with 239,680 ha of SDI, but had only $22 \%$ of the total SDI + DI land area in SDI. Processing tomato is the primary SDI crop in California, and SDI has become a primary method because of its yield and quality advantages

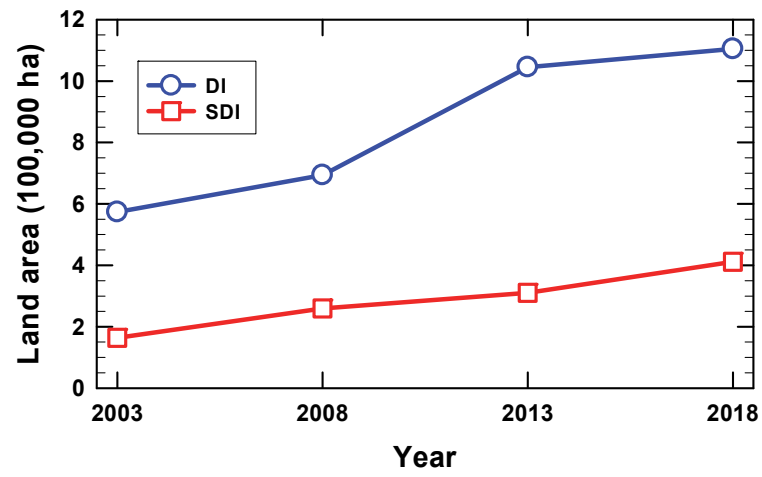

Figure 1. Growth of land area in the U.S. using surface drip irrigation (DI) and subsurface drip irrigation (SDI) from 2003 to 2018 according to USDA-NASS surveys (USDA-NASS, 2004, 2010, 2014, 2018).
(Montazar, UC-Davis, personal communication, 2015). Although the SDI land areas in states such as Arizona, Kansas, Nebraska, and Texas are much smaller than in California, the ratio of SDI / (SDI + DI) is much greater, likely reflecting the economics of irrigated crop production in those states. A deeper, multi-year SDI system that can be amortized over several years is often the only economical microirrigation option for producers growing lower-value commodity crops such as cotton and corn.

\section{SDI RESEARCH IN THE U.S.} RESEARCH DISCOVERY METHOD

Broad efforts to uncover published, peer-reviewed U.S. research related to SDI for the period from 2010 through 2020 were conducted. These efforts are described below.

Initially, an effort was made by the first author in 2019 to identify all institutional (e.g., universities and federal agencies) irrigation engineers and scientists within the U.S. through various listservs, email contacts, institutional lists, and key contacts to regional irrigation specialists. Following this listing of U.S. irrigation specialists, all individuals on the list were contacted requesting citations of SDI research published during the specified period.

A search of the USDA-NIFA Current Research Information System (CRIS) was conducted in 2019 with the following keywords: drip irrigation, microirrigation, micro-irrigation, micro irrigation, subsurface drip irrigation, SDI, and trickle irrigation. In addition to the larger research efforts being conducted at many institutions, this search helped identify smaller SDI research efforts and more esoteric uses of the technology within the agricultural and horticultural topic areas. The CRIS listing, although cumbersome to use because of duplicate cross-listings, identified both pertinent citations and additional SDI specialists who had not been previously identified. These individuals were also contacted requesting citations of SDI research published during the specified period.

The USDA-NIFA W-4128 multi-state regional five-year project concerning microirrigation, titled Microirrigation: A Sustainable Technology for Crop Intensification and Improved Water Productivity, with a start date of 1 October 2019, involves several of this article's authors and was another source of information about published research and regional status of SDI technology. This regional project began in 1972 as W-128 and was succeeded by W-1128 in 2004, $\mathrm{W}-2128$ in $2009, \mathrm{~W}-3128$ in 2014 . The titles of the other two projects overlapping the 2010 to 2020 period were $\mathrm{W}-2128$ : Microirrigation for Sustainable Water Use, and W-3128: Scaling Microirrigation Technologies to Address Global Water Challenges.

Additional pertinent citations were gleaned from the table of contents listings of peer-reviewed journals that publish irrigation-related research, including Transactions of the ASABE, Applied Engineering in Agriculture, Irrigation Science, ASCE Journal of Irrigation and Drainage Engineering, Agricultural Water Management, Agronomy Journal, Soil Science Society of America Journal, and Crop Science.

Finally, the references cited in each discovered research article were examined for additional pertinent citations. 


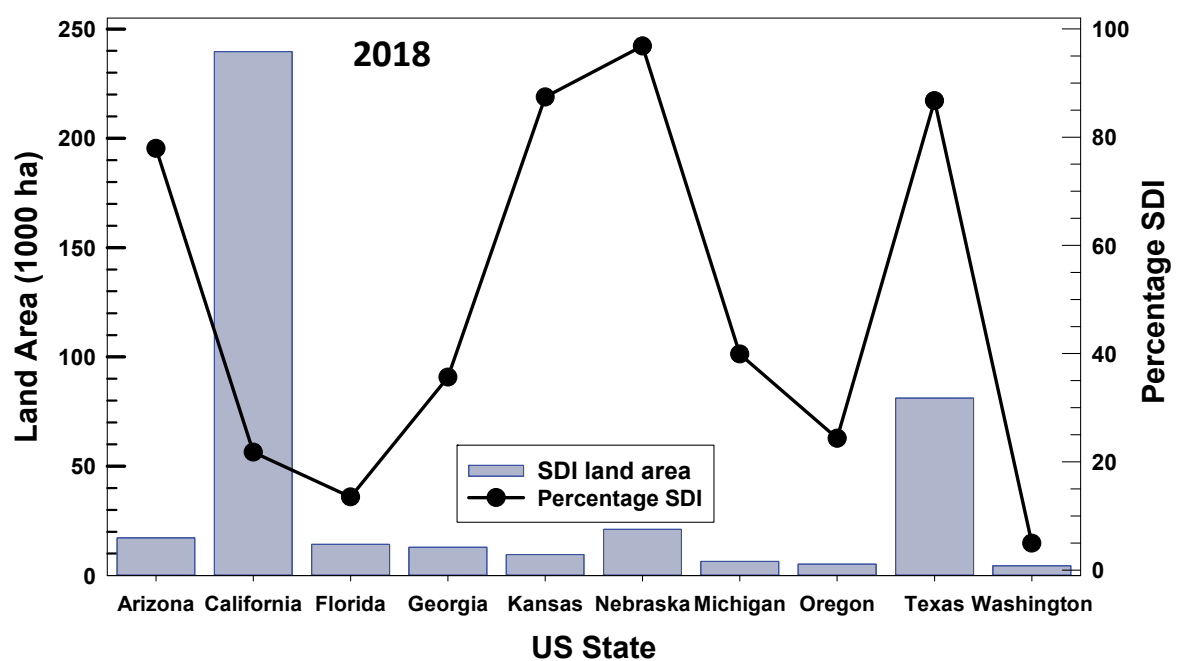

Figure 2. Characteristics of SDI use in the ten U.S. states having the largest land area devoted to SDI. The percentage of SDI refers to the ratio of SDI to total drip-irrigated land area (total SDI and surface drip irrigation (DI)). Data are summarized from USDA-NASS (2018).

Overall, 162 published, peer-reviewed U.S. research reports concerning SDI were identified as having been published during the period 2010 to 2020 . Although there are likely to be studies that remained undiscovered by this review process, this summary should be reasonably representative of the U.S. effort.

\section{RESEARCH CATEgorization}

Broad crop categories of the studies were established to make the tabular listings (i.e., tables 2 through 6) and the subsequent discussion of the research more manageable. These SDI research crop categories were:

- Cotton

- Grain and oilseed crops

- Horticultural crops

- Forage crops

- Turf grasses

- No specific crop.

A few studies (12 of 162) overlapped some of these crop categories, and those studies are listed in each appropriate crop table. Within each of the crop tables, subheadings are used to further categorize the studies using hierarchical criteria chosen by the authors based on prevailing topic areas that appeared to emerge from the studies. These subcategories include:

- Studies comparing SDI to alternative irrigation systems and also possibly to dryland production or possibly to improve SDI performance.

- Studies comparing SDI to dryland production and possibly to improve an aspect of SDI performance.

- Studies attempting to evaluate a response specifically for SDI or to improve SDI performance.

- Studies primarily using SDI as an efficient or convenient irrigation system.

It can be argued that studies that primarily used SDI as an efficient or convenient irrigation system could have been excluded from the review as not being especially pertinent. Their inclusion was based on trying to help future SDI researchers make preliminary judgements about their pertinence. Perhaps more importantly, these studies clearly demonstrated SDI as a feasible, long-term, and efficient irrigation technology within a specific crop category.

If a research report fell within an upper subcategory (of the four subcategories), that categorization prevailed, and the study was not included more than once within a given crop table, thus explaining the detailed wording of the subcategories.

\section{CotTon}

A total of 44 studies involving cotton were found in the review process (table 2) spread across the four subcategories.

\section{SDI IN COMPARISON TO ALTERNATIVE IRRIGATION SYSTEMS FOR COTTON PRODUCTION}

Seven studies (table 2) compared SDI to alternative irrigation systems, e.g., furrow irrigation (FI), surface gravity irrigation (SGI), sprinkler irrigation (SprI), or surface drip irrigation (DI). In five of the seven studies, SDI had at least some benefit in cotton production, and in two studies it did not. Stated SDI benefits varied between studies but included yield increases ( $\mathrm{Sij}$ et al., 2010; Lamm, 2016; Barnes et al., 2020; Sorensen et al., 2020), reduction in greenhouse gas (GHG) emissions (Bronson et al., 2018), and greater profitability (Sij et al., 2010). Negative responses attributed to SDI included a reduction in small rainfall event utilization (Goebel and Lascano, 2019) and a greater incidence of spider mite damage (Hollingsworth et al., 2014). Additional information on cotton response to SDI and alternative irrigation systems from a global and longer-term perspective was provided by Lamm (2016).

\section{SDI IN COMPARISON TO DRYLAND COTTON}

Dryland production of cotton exists in much of the southeast U.S. and is often included as a treatment even in irrigation research studies in the semi-arid cotton production areas farther west (e.g., Texas). Nine studies from the southeast U.S. (specifically Alabama, Georgia, North Carolina) 
Table 2. Identified SDI research studies in the U.S. concerning cotton, 2010 through 2020.

\begin{tabular}{|c|c|c|c|c|c|c|c|c|c|}
\hline \multirow[b]{2}{*}{ Study } & \multirow[b]{2}{*}{$\begin{array}{c}\text { Highlights and Other Reported } \\
\text { Factors or Data } \\
\end{array}$} & \multirow[b]{2}{*}{$\begin{array}{l}\text { Study } \\
\text { Type }\end{array}$} & \multirow{2}{*}{$\begin{array}{l}\text { U.S. State } \\
\text { and/or } \\
\text { Region }\end{array}$} & \multirow[b]{2}{*}{$\begin{array}{l}\text { Soil } \\
\text { Type }\end{array}$} & \multicolumn{2}{|c|}{ Driplines $^{[\mathrm{a}]}$} & \multirow{2}{*}{$\begin{array}{l}\text { No. of } \\
\text { Water } \\
\text { Levels }\end{array}$} & \multirow[b]{2}{*}{$\begin{array}{l}\text { Crop } \\
\text { Yield }\end{array}$} & \multirow[b]{2}{*}{$\begin{array}{c}\text { SDI } \\
\text { Benefit }\end{array}$} \\
\hline & & & & & $\begin{array}{l}\text { Depth } \\
(\mathrm{m})\end{array}$ & $\begin{array}{l}\text { Spacing } \\
(\mathrm{m})\end{array}$ & & & \\
\hline \multicolumn{10}{|c|}{ Studies comparing SDI to alternative irrigation systems and also possibly to dryland production or possibly to improve SDI performance } \\
\hline $\begin{array}{c}\text { Barnes et al., } \\
2020 \\
\end{array}$ & $\begin{array}{l}\text { Much growth of SDI area in Texas. } \\
\text { Other: SGI and SprI. }\end{array}$ & Summary & $\begin{array}{l}\text { Cotton } \\
\text { regions }\end{array}$ & NA & NA & NA & NA & NA & Yes \\
\hline $\begin{array}{c}\text { Bronson } \\
\text { et al., } 2018 \\
\end{array}$ & $\begin{array}{l}\text { Less GHG emissions with SDI than } \\
\text { for FI and SprI. Other: Fertigation. }\end{array}$ & Field & $\begin{array}{l}\text { Arizona } \\
(\mathrm{SW})\end{array}$ & $\begin{array}{c}\text { Sandy } \\
\text { clay loam }\end{array}$ & $\begin{array}{c}0.22 \text { to } \\
0.28\end{array}$ & 1.0 & 1 & No & Yes \\
\hline $\begin{array}{c}\text { Goebel and } \\
\text { Lascano, } 2019\end{array}$ & $\begin{array}{c}\text { Dryland and SprI used small } \\
\text { rainfall events better than SDI. }\end{array}$ & Field & $\begin{array}{l}\text { Texas } \\
(\mathrm{SW})\end{array}$ & $\begin{array}{l}\text { Fine sandy } \\
\text { loam }\end{array}$ & 0.3 & 2.0 & 1 & No & No \\
\hline $\begin{array}{l}\text { Hollingsworth } \\
\text { et al., } 2014\end{array}$ & $\begin{array}{l}\text { Spider mites were worse } \\
\text { for SDI than for SprI. }\end{array}$ & Field & $\begin{array}{l}\text { California } \\
\text { (W) }\end{array}$ & Clay loam & 0.3 & 0.76 & 1 & Yes & No \\
\hline Lamm, 2016 & $\begin{array}{l}\text { Adoption of SDI for cotton seemed } \\
\text { related to increased yields. } \\
\text { Other: DI, SGI, and SprI; Fertigation; } \\
\text { and Tomato, corn, and onion. }\end{array}$ & $\begin{array}{l}\text { Review/ } \\
\text { Summary }\end{array}$ & $\begin{array}{c}\text { Not } \\
\text { limited } \\
\text { to U.S. }\end{array}$ & NA & Various & Various & Various & Yes & $\begin{array}{l}\text { Mixed } \\
\text { results }\end{array}$ \\
\hline $\begin{array}{c}\text { Sij et al., } \\
2010\end{array}$ & $\begin{array}{c}\text { SDI had improved yield and } \\
\text { economics over SprI. }\end{array}$ & Field & $\begin{array}{l}\text { Texas } \\
(\mathrm{SW})\end{array}$ & $\begin{array}{c}\text { Fine sandy } \\
\text { loam }\end{array}$ & $\begin{array}{c}0.30 \text { to } \\
0.35\end{array}$ & $\begin{array}{c}1.0 \text { or } \\
2.0\end{array}$ & 2 & Yes & Yes \\
\hline $\begin{array}{l}\text { Sorensen } \\
\text { et al., } 2020\end{array}$ & $\begin{array}{c}\text { Shallow } \mathrm{S}^{3} \mathrm{DI} \text { and SprI had greater yield } \\
\text { than deeper SDI under full irrigation. } \\
\text { Other: Dryland. }\end{array}$ & Field & $\begin{array}{l}\text { Georgia } \\
\text { (SE) }\end{array}$ & $\begin{array}{l}\text { Fine sandy } \\
\text { loam }\end{array}$ & $\begin{array}{l}0.05 \text { or } \\
0.25 \text { to } \\
0.30\end{array}$ & $\begin{array}{c}0.9 \text { or } \\
1.8\end{array}$ & 5 & Yes & $\begin{array}{l}\text { Mixed } \\
\text { results }\end{array}$ \\
\hline \multicolumn{10}{|c|}{ Studies comparing SDI to dryland production and possibly to improve an aspect of SDI performance } \\
\hline $\begin{array}{l}\text { AbdelGadir } \\
\text { et al., } 2011\end{array}$ & $\begin{array}{c}\text { Parallel vs. perpendicular SDI } \\
\text { orientation was evaluated, and } \\
\text { maximum yield was } 74 \% \text { of Epan. }\end{array}$ & Field & $\begin{array}{l}\text { Alabama } \\
\text { (SE) }\end{array}$ & Silt loam & 0.38 & 2.0 & 4 & Yes & Yes \\
\hline $\begin{array}{l}\text { Attia and Rajan, } \\
2016\end{array}$ & $\begin{array}{l}\text { SDI yielded more than dryland } \\
\text { and various crop indexes could be } \\
\text { used for scheduling irrigation. }\end{array}$ & Field & $\begin{array}{l}\text { Texas } \\
\text { (SW) }\end{array}$ & Clay loam & 0.3 & 1.0 & 4 & Yes & Yes \\
\hline $\begin{array}{c}\text { Attia et al., } \\
2015 \\
\end{array}$ & $\begin{array}{l}\text { SDI yield increased with irrigation } \\
\text { up to } 90 \% \text { ET level. }\end{array}$ & Field & $\begin{array}{l}\text { Texas } \\
(\mathrm{SW}) \\
\end{array}$ & Clay loam & 0.3 & 1.0 & 4 & Yes & Yes \\
\hline $\begin{array}{c}\text { Baker et al., } \\
2013\end{array}$ & $\begin{array}{l}\text { Irrigation scheduling can be improved } \\
\text { using canopy temperature and other } \\
\text { weather variables. Other: WP. }\end{array}$ & Field & $\begin{array}{l}\text { Texas } \\
\text { (SW) }\end{array}$ & $\begin{array}{l}\text { Fine sandy } \\
\text { loam }\end{array}$ & 0.4 & 1.0 & 7 & Yes & Yes \\
\hline $\begin{array}{l}\text { Baker et al., } \\
2015\end{array}$ & $\begin{array}{l}\text { SDI lint yield was greater than } \\
\text { dryland, and WP was optimized } \\
\text { at less than maximum yield. }\end{array}$ & Field & $\begin{array}{l}\text { Texas } \\
\text { (SW) }\end{array}$ & $\begin{array}{l}\text { Fine sandy } \\
\text { loam }\end{array}$ & 0.4 & 1.0 & 6 & Yes & Yes \\
\hline $\begin{array}{c}\text { Chastain } \\
\text { et al., 2016a }\end{array}$ & $\begin{array}{l}\text { SDI yielded more than dryland, and } \\
\text { using leaf water potential improved WP. }\end{array}$ & Field & $\begin{array}{l}\text { Georgia } \\
\text { (SE) }\end{array}$ & $\begin{array}{c}\text { Coarse } \\
\text { textured }\end{array}$ & 0.3 & 1.8 & 5 & Yes & $\begin{array}{l}\text { Mixed } \\
\text { results }\end{array}$ \\
\hline $\begin{array}{l}\text { Feng et al., } \\
2014\end{array}$ & $\begin{array}{l}\text { Both weather and irrigation level } \\
\text { impacted cotton fiber quality and lint } \\
\text { yield. Other: Fertigation; Economics. }\end{array}$ & Field & $\begin{array}{l}\text { Texas } \\
(\mathrm{SW})\end{array}$ & $\begin{array}{l}\text { Sandy clay } \\
\text { loam, clay } \\
\text { loam }\end{array}$ & 0.25 & NA & 3 & Yes & $\begin{array}{l}\text { Mixed } \\
\text { results }\end{array}$ \\
\hline $\begin{array}{l}\text { Jordan et al., } \\
2014\end{array}$ & $\begin{array}{l}\text { Economics for cotton for SDI was } \\
\text { justified but only in } 50 \% \text { of years. } \\
\text { Other: Economics; Corn and peanut. }\end{array}$ & Field & $\begin{array}{l}\text { North } \\
\text { Carolina } \\
\text { (SE) }\end{array}$ & $\begin{array}{l}\text { Sandy } \\
\text { loam }\end{array}$ & 0.25 & 0.9 & 2 & Yes & $\begin{array}{l}\text { Mixed } \\
\text { results }\end{array}$ \\
\hline $\begin{array}{l}\text { Nuti et al., } \\
2012\end{array}$ & $\begin{array}{l}\text { SDI improved yield stability over rainfed. } \\
\text { Planting dates and the effects of } \\
\text { mepiquat chloride were investigated. }\end{array}$ & Field & $\begin{array}{l}\text { North } \\
\text { Carolina } \\
\text { (SE) }\end{array}$ & $\begin{array}{l}\text { Sandy } \\
\text { loam }\end{array}$ & 0.25 & 1.8 & 2 & Yes & Yes \\
\hline $\begin{array}{c}\text { Sorensen and } \\
\text { Lamb, } 2019\end{array}$ & $\begin{array}{l}\text { Shallow } \mathrm{S}^{3} \mathrm{DI} \text { increased yield over } \\
\text { dryland condition except in wet year. }\end{array}$ & Field & $\begin{array}{c}\text { Georgia } \\
\text { (SE) }\end{array}$ & $\begin{array}{l}\text { Fine sandy } \\
\text { loam }\end{array}$ & 0.05 & 1.8 & 4 & Yes & Yes \\
\hline $\begin{array}{l}\text { Sorensen et al., } \\
2010 \mathrm{~b}\end{array}$ & $\begin{array}{c}\text { NR for shallow } \mathrm{S}^{3} \mathrm{DI} \text { replaced annually } \\
\text { was sufficient for cotton and corn, } \\
\text { but not peanut. Other: Economics. }\end{array}$ & Field & $\begin{array}{l}\text { Georgia } \\
\text { (SE) }\end{array}$ & $\begin{array}{l}\text { Fine sandy } \\
\text { loam }\end{array}$ & 0.05 & 1.8 & 1 & Yes & Yes \\
\hline $\begin{array}{l}\text { Sorensen et al., } \\
2016\end{array}$ & $\begin{array}{l}\text { Shallow } \mathrm{S}^{3} \mathrm{DI} \text { replaced every } 3 \text { years } \\
\text { was economical in this region for cotton, } \\
\text { corn, and peanut compared to dryland. }\end{array}$ & Field & $\begin{array}{l}\text { Georgia } \\
\text { (SE) }\end{array}$ & $\begin{array}{l}\text { Fine sandy } \\
\text { clay loam }\end{array}$ & 0.03 & 1.8 & 2 & Yes & Yes \\
\hline $\begin{array}{l}\text { Spivey et al., } \\
2019\end{array}$ & $\begin{array}{l}\text { SDI increased yields in years } \\
\text { where drought occurred. }\end{array}$ & Field & $\begin{array}{l}\text { North } \\
\text { Carolina } \\
\text { (SE) }\end{array}$ & $\begin{array}{l}\text { Sandy } \\
\text { loam }\end{array}$ & 0.3 & NA & 2 & Yes & Yes \\
\hline
\end{tabular}

and six studies from semi-arid Texas were found for the 2010 to 2020 period comparing SDI to dryland cotton (table 2 spanning the upper two subcategories). In the 14 studies that reported yields, SDI had increased yields over dryland production except in years of abundant rainfall for the southeast U.S. Most of the studies in the humid southeast U.S. were conducted on coarse-textured soils, and thus cotton yield would likely be more responsive to drought on these soils.

\section{STUdies OF SDI RESPONSES AND/OR PERFORMANCE IMPROVEMENTS FOR COTTON PRODUCTION}

Other SDI cotton studies ( 16 when spread across multiple subcategories in table 2) focused more on evaluating a response specific for SDI or on improving SDI performance for cotton. Dripline depth, spacing, and/or orientation (Sij et al., 2010; AbdelGadir et al., 2011; Bufon et al., 2011; Sorensen et al., 2011, 2020; Bordovsky and Mustian, 2012, 2020) was a topic in seven studies (table 2 spanning two 
Table 2 (continued). Identified SDI research studies in the U.S. concerning cotton, 2010 through 2020.

\begin{tabular}{|c|c|c|c|c|c|c|c|c|c|}
\hline \multirow[b]{2}{*}{ Study } & \multirow[b]{2}{*}{$\begin{array}{c}\text { Highlights and Other Reported } \\
\text { Factors or Data } \\
\end{array}$} & \multirow[b]{2}{*}{$\begin{array}{l}\text { Study } \\
\text { Type }\end{array}$} & \multirow{2}{*}{$\begin{array}{l}\text { U.S. State } \\
\text { and/or } \\
\text { Region }\end{array}$} & \multirow[b]{2}{*}{$\begin{array}{c}\text { Soil } \\
\text { Type }\end{array}$} & \multicolumn{2}{|c|}{ Driplines $^{[\mathrm{a}]}$} & \multirow{2}{*}{$\begin{array}{l}\text { No. of } \\
\text { Water } \\
\text { Levels }\end{array}$} & \multirow[b]{2}{*}{$\begin{array}{l}\text { Crop } \\
\text { Yield }\end{array}$} & \multirow[b]{2}{*}{$\begin{array}{c}\text { SDI } \\
\text { Benefit }\end{array}$} \\
\hline & & & & & $\begin{array}{l}\text { Depth } \\
(\mathrm{m})\end{array}$ & $\begin{array}{l}\text { Spacing } \\
(\mathrm{m})\end{array}$ & & & \\
\hline \multicolumn{10}{|c|}{ Studies attempting to evaluate a response specifically for SDI or to improve SDI performance } \\
\hline $\begin{array}{l}\text { Bordovsky and } \\
\text { Mustian, } 2012\end{array}$ & $\begin{array}{c}\text { Opportunities exist to manage cotton } \\
\text { row spacing and dripline orientation. } \\
\text { Other: Fertigation; Economics. }\end{array}$ & Field & $\begin{array}{l}\text { Texas } \\
\text { (SW) }\end{array}$ & Clay loam & 0.35 & $\begin{array}{l}0.76,1.0 \\
\text { or } 1.52\end{array}$ & 2 & Yes & NA \\
\hline $\begin{array}{l}\text { Bordovsky and } \\
\text { Mustian, } 2020\end{array}$ & $\begin{array}{c}\text { Planting date and SDI/crop orientation } \\
\text { affected yield and water use. } \\
\text { Other: Fertigation; Economics. } \\
\end{array}$ & Field & $\begin{array}{l}\text { Texas } \\
(\mathrm{SW})\end{array}$ & Clay loam & 0.3 & $\begin{array}{l}1.0 \text { or } \\
2.0\end{array}$ & 2 & Yes & NA \\
\hline $\begin{array}{l}\text { Bordovsky, } \\
2020\end{array}$ & $\begin{array}{l}\text { SDI productivity can be improved by } \\
\text { restricting early or preplant irrigation. } \\
\text { Other: Fertigation; WP; Economics. }\end{array}$ & Field & $\begin{array}{l}\text { Texas } \\
(\mathrm{SW})\end{array}$ & Clay loam & $\begin{array}{l}0.2 \text { and } \\
0.3\end{array}$ & $\begin{array}{l}0.76 \text { and } \\
1.52\end{array}$ & $\begin{array}{c}7 \text { and } \\
4\end{array}$ & Yes & Yes \\
\hline $\begin{array}{l}\text { Bronson et al., } \\
2011\end{array}$ & $\begin{array}{l}\text { Reflectance-based N strategy saved N } \\
\text { and maintained yield. Other: Fertigation. }\end{array}$ & Field & $\begin{array}{l}\text { Texas } \\
(\mathrm{SW})\end{array}$ & $\begin{array}{l}\text { Sandy clay } \\
\text { loam }\end{array}$ & 0.3 & 2.0 & 1 & Yes & NA \\
\hline $\begin{array}{c}\text { Bronson et al., } \\
2019\end{array}$ & $\begin{array}{l}\text { Reflectance-based N strategy saved N and } \\
\text { maintained yield. Other: Fertigation. }\end{array}$ & Field & $\begin{array}{l}\text { Arizona } \\
(\mathrm{SW})\end{array}$ & $\begin{array}{l}\text { Sandy } \\
\text { loam }\end{array}$ & $\begin{array}{c}0.22 \text { and } \\
0.28\end{array}$ & 1.0 & 2 & Yes & NA \\
\hline $\begin{array}{c}\text { Bufon et al., } \\
2012 \\
\end{array}$ & $\begin{array}{l}\text { Hydrus 2-D modeling can be used } \\
\text { to evaluate irrigation strategies. }\end{array}$ & $\begin{array}{l}\text { Modeling } \\
\text { /Field }\end{array}$ & $\begin{array}{l}\text { Texas } \\
(\mathrm{SW}) \\
\end{array}$ & $\begin{array}{c}\text { Fine sandy } \\
\text { loam }\end{array}$ & 0.32 & 2.0 & 3 & NA & NA \\
\hline $\begin{array}{l}\text { DeLaune et al., } \\
2012\end{array}$ & $\begin{array}{l}\text { Adoption of no tillage with SDI } \\
\text { should not affect lint yield. }\end{array}$ & Field & $\begin{array}{l}\text { Texas } \\
(\mathrm{SW})\end{array}$ & Clay loam & 0.3 & 1.0 & 5 & Yes & Yes \\
\hline $\begin{array}{c}\text { DeLaune et al., } \\
2020\end{array}$ & $\begin{array}{l}\text { Improved SDI timing and conservation } \\
\text { tillage increased lint yield. }\end{array}$ & Field & $\begin{array}{l}\text { Texas } \\
(\mathrm{SW})\end{array}$ & Clay loam & 0.3 & 1.0 & 3 & Yes & NA \\
\hline $\begin{array}{l}\text { Sorensen and } \\
\text { Lamb, } 2015\end{array}$ & $\begin{array}{l}\text { Longevity for shallow } \mathrm{S}^{3} \mathrm{DI} \text { estimated } \\
\text { to be economically } 5.4 \text { years. } \\
\text { Other: Corn and peanut; Economics. }\end{array}$ & Field & $\begin{array}{l}\text { Georgia } \\
\text { (SE) }\end{array}$ & $\begin{array}{l}\text { Fine sandy } \\
\text { loam }\end{array}$ & 0.038 & 1.8 & 1 & Yes & NA \\
\hline $\begin{array}{l}\text { Sorensen et al., } \\
2011\end{array}$ & $\begin{array}{l}\text { SDI with } 75 \% \text { full irrigation had the } \\
\text { best yield. Wider }(1.8 \mathrm{~m}) \text { alternate row } \\
\text { spacing was recommended, but } 0.9 \mathrm{~m} \\
\text { spacing sometimes had greater yield. }\end{array}$ & Field & $\begin{array}{l}\text { Georgia } \\
\text { (SE) }\end{array}$ & $\begin{array}{l}\text { Sandy } \\
\text { loam }\end{array}$ & 0.3 & $\begin{array}{c}0.9 \text { or } \\
1.8\end{array}$ & 3 & Yes & Yes \\
\hline \multicolumn{10}{|c|}{ Studies primarily using SDI as an efficient or convenient irrigation system } \\
\hline $\begin{array}{l}\text { Allen et al., } \\
2012\end{array}$ & $\begin{array}{l}\text { Integrated crop/livestock system used } \\
\text { less irrigation and chemicals than } \\
\text { monoculture cotton. Other: Economics. }\end{array}$ & Field & $\begin{array}{l}\text { Texas } \\
\text { (SW) }\end{array}$ & Clay loam & 0.36 & 1.0 & 1 & Yes & NA \\
\hline $\begin{array}{c}\text { Burke and } \\
\text { Ulloa, } 2017\end{array}$ & $\begin{array}{l}\text { Timing of deficit irrigation can affect } \\
\text { sensitivity to water stress. }\end{array}$ & Field & $\begin{array}{l}\text { Texas } \\
(\mathrm{SW})\end{array}$ & $\begin{array}{l}\text { Fine sandy } \\
\text { loam }\end{array}$ & NA & NA & 2 & Yes & NA \\
\hline $\begin{array}{c}\text { Attia et al., } \\
2016 \\
\end{array}$ & $\begin{array}{l}\text { Scheduling irrigation based on ET } \\
\text { could increase yield, WP, and profit. }\end{array}$ & $\begin{array}{l}\text { Modeling } \\
\text { /Field }\end{array}$ & $\begin{array}{l}\text { Texas } \\
(\mathrm{SW})\end{array}$ & Clay loam & 0.3 & 1.0 & 1 & Yes & NA \\
\hline $\begin{array}{c}\text { Chastain et al., } \\
2016 \mathrm{~b}\end{array}$ & $\begin{array}{l}\text { Young leaves are more tolerant } \\
\text { of heat and drought. }\end{array}$ & Field & $\begin{array}{l}\text { Georgia } \\
\text { (SE) }\end{array}$ & $\begin{array}{l}\text { Loamy } \\
\text { sand }\end{array}$ & 0.3 & 1.8 & 1 & No & NA \\
\hline $\begin{array}{c}\text { Johnson et al., } \\
2013 \\
\end{array}$ & $\begin{array}{l}\text { Less risk with crop/livestock system than } \\
\text { monoculture cotton. Other: Economics. }\end{array}$ & Field & $\begin{array}{l}\text { Texas } \\
(\mathrm{SW}) \\
\end{array}$ & NA & 0.36 & 1 & 1 & Yes & NA \\
\hline $\begin{array}{c}\text { Li et al., } \\
2013 \\
\end{array}$ & $\begin{array}{l}\text { Cattle grazing and allelopathy of rye } \\
\text { were discussed as related to cotton. }\end{array}$ & Field & $\begin{array}{l}\text { Texas } \\
(\mathrm{SW})\end{array}$ & Clay loam & NA & NA & 1 & Yes & NA \\
\hline $\begin{array}{l}\text { Pabuayon } \\
\text { et al., } 2019\end{array}$ & $\begin{array}{l}\text { Biomass and yield of cotton and grain } \\
\text { sorghum increased under irrigation, } \\
\text { but not for sesame. Other: WP. }\end{array}$ & Field & $\begin{array}{l}\text { Texas } \\
(\mathrm{SW})\end{array}$ & Clay loam & NA & NA & 4 & Yes & NA \\
\hline $\begin{array}{c}\text { Rajan et al., } \\
2010 \\
\end{array}$ & $\begin{array}{l}\text { Method to determine crop water } \\
\text { use was reported. }\end{array}$ & Field & $\begin{array}{l}\text { Texas } \\
(\mathrm{SW})\end{array}$ & Clay loam & NA & NA & 1 & No & No \\
\hline $\begin{array}{c}\text { Snowden et al., } \\
2013 \mathrm{a}\end{array}$ & $\begin{array}{l}\text { Cultivars should be evaluated for deficit } \\
\text { irrigation. Other: Fertigation; WP. }\end{array}$ & Field & $\begin{array}{l}\text { Texas } \\
(\mathrm{SW})\end{array}$ & Clay loam & $\begin{array}{c}0.20 \text { to } \\
0.24\end{array}$ & 1.0 & 3 & Yes & NA \\
\hline $\begin{array}{c}\text { Snowden et al., } \\
2013 \mathrm{~b} \\
\end{array}$ & $\begin{array}{l}\text { Cultivars differed in yield compensation } \\
\text { to irrigation. Other: Fertigation. }\end{array}$ & Field & $\begin{array}{l}\text { Texas } \\
(\mathrm{SW}) \\
\end{array}$ & Clay loam & $\begin{array}{c}0.20 \text { to } \\
0.24\end{array}$ & 1.0 & 4 & Yes & NA \\
\hline $\begin{array}{c}\text { Snowden et al., } \\
2014\end{array}$ & $\begin{array}{c}\text { Drought stress at early flowering resulted } \\
\text { in lowest yield. Other: Fertigation. }\end{array}$ & Field & $\begin{array}{l}\text { Texas } \\
(\mathrm{SW})\end{array}$ & Clay loam & $\begin{array}{l}0.20 \text { to } \\
0.24\end{array}$ & 1.0 & 5 & Yes & NA \\
\hline $\begin{array}{c}\text { Sorensen and } \\
\text { Lamb, } 2016\end{array}$ & Crop response to biochar rate minimal. & Field & $\begin{array}{c}\text { Georgia } \\
\text { (SE) }\end{array}$ & $\begin{array}{c}\text { Fine sandy } \\
\text { loam }\end{array}$ & 0.05 & NA & 1 & Yes & NA \\
\hline $\begin{array}{l}\text { Zilverberg } \\
\text { et al., } 2012 \\
\end{array}$ & $\begin{array}{l}\text { Monoculture cotton used more energy } \\
\text { than integrated crop/livestock system. }\end{array}$ & Field & $\begin{array}{l}\text { Texas } \\
(\mathrm{SW})\end{array}$ & Clay loam & 0.36 & 1.0 & 1 & No & NA \\
\hline $\begin{array}{l}\text { Zilverberg } \\
\text { et al., } 2014\end{array}$ & $\begin{array}{l}\text { Monoculture cotton used more irrigation } \\
\text { than integrated crop/livestock system. }\end{array}$ & Field & $\begin{array}{l}\text { Texas } \\
(\mathrm{SW})\end{array}$ & Clay loam & 0.36 & 1.0 & 2 & Yes & NA \\
\hline
\end{tabular}

subcategories). Additional studies on SDI depth, spacing, and orientation from a global and longer-term perspective was provided by Lamm (2016).

An innovative use of SDI in the southeast U.S. (Sorensen et al., 2020) using shallow SDI (0.05 $\mathrm{m}$ depth), termed as $\mathrm{S}^{3} \mathrm{DI}$, had greater cotton lint yield than deeper SDI $(0.25$ to
$0.30 \mathrm{~m}$ ) on a fine sandy loam. The term $\mathrm{S}^{3} \mathrm{DI}$ was first reported by Sorensen et al. (2010b) but emanated from earlier research (Sorensen et al., 2007). Cotton in this region is often grown in a three-year rotation of cotton, corn, and peanut, with peanut being the most profitable crop. Net returns were great enough with cotton and corn to justify annual 
replacement of the $S^{3}$ DI system, but not so for peanut, where yield increases attributable to $\mathrm{S}^{3} \mathrm{DI}$ were not great enough (Sorensen et al., 2010b). In areas with extreme water shortages, the increased yields from SDI due to the greater efficiency of these systems may justify annual replacement. Later work in which $\mathrm{S}^{3} \mathrm{DI}$ was replaced every three years was found to be profitable for all three crops, i.e., cotton, corn, and peanut (Sorensen et al., 2016), and the longevity of $\mathrm{S}^{3} \mathrm{DI}$ has been estimated to be 5.4 years for the cottoncorn-peanut rotation (Sorensen and Lamb, 2015). The vast majority of the other studies in table 2 reported a dripline depth of 0.2 to $0.4 \mathrm{~m}$. Average dripline depths of $0.33 \mathrm{~m}$ were reported for 13 cotton studies conducted between 1966 and 1997 (Camp, 1998) and $0.32 \mathrm{~m}$ reported by Lamm (2016) for 15 studies conducted between 1970 and 2010.

A dripline spacing of $0.9 \mathrm{~m}$ generally had greater lint yield than a spacing of $1.8 \mathrm{~m}$ for cotton on a sandy loam soil in Georgia (Sorensen et al., 2011), but the wider spacing was recommended due to insufficient yield increases to justify additional system costs. In another study in the southeast U.S. on a silt loam soil, little differences in lint yield were noted in parallel and perpendicular crop row and dripline orientations for a $2 \mathrm{~m}$ dripline spacing (AbdelGadir et al., 2011). Research in Texas on a clay loam soil (Bordovsky and Mustian, 2012) found that narrowing the cotton rows from 1.02 to $0.76 \mathrm{~m}$ for dripline spacings of $0.76,1.02$, and $1.52 \mathrm{~m}$ had no statistical effect on yields (NS at $\mathrm{p}=0.05)$ for parallel dripline and crop row orientations, but was significant for perpendicular orientations. In a later study at the same location (Bordovsky and Mustian, 2020), strategies were evaluated to improve cotton establishment in this semiarid environment when using SDI. The researchers found that both the planting date and the distance from the crop row to the dripline affected crop establishment, lint yield, and water use. Late planting resulted in significantly greater plant density (i.e., plants per area) but significantly reduced lint yield. Narrower dripline spacing $(1.0$ vs. $2.0 \mathrm{~m})$ increased yield, and positioning the crop rows closer to the dripline also increased yield. However, positioning the crop row directly above the lateral with or without the inclusion of an adjacent non-irrigated crop row was recommended only as a strategy to consider for a very late plant window under drought conditions. In another study (Sij et al., 2010) in Texas on a fine sandy loam, lint yield (three-year average) was not significantly different for dripline spacings of 1 or $2 \mathrm{~m}$, nor by inclusion or not of a cover crop of rye. The usefulness of Hydrus 2D modeling was demonstrated for cotton production in another study on the Texas High Plains (Bufon et al., 2011) that found that volumetric soil water content could be simulated within $3 \%$ of measured values for various installation geometries and irrigation strategies. Approximately half of the studies listed in table 2 used dripline spacings of $1.0 \mathrm{~m}$, which typically corresponds to one dripline for every crop row.

Soil water evaporation can be minimized with SDI, so opportunities to grow cotton using systems with less irrigation capacity (i.e., volume over time) through applying preseason or early-season irrigation exist on deep soils with good water-holding capacity. However, in a five-year study on a clay loam soil in Texas, Bordovsky (2020) concluded that SDI productivity for cotton could be improved by limiting early or preseason irrigation even when deficit irrigated. Although drier soil surfaces limit evaporative losses for SDI, small rainfall events were found to be less effective for SDI as compared to center pivot sprinkler irrigation (CP) on a fine sandy loam in Texas (Goebel and Lascano, 2019).

SDI systems are well suited for either continuous or frequent fertigation, but fertigation was only mentioned in study procedures for 8 of the 44 studies listed in table 2 . Only two studies had a primary goal of improving fertigation scheduling for cotton. In both studies on sandy loam soil in Texas (Bronson et al., 2011) and in Arizona (Bronson et al., 2019), reflectance-based nitrogen (N) fertigation treatments saved $31 \%$ of $\mathrm{N}$ over soil test-based treatments without reducing lint yields. In an emerging study topic area, SDI fertigation was found to have less nitrous oxide (i.e., a GHG) emissions than furrow irrigation and SprI (Bronson et al., 2018). Four additional GHG studies (Kallenbach et al., 2010; Kennedy et al., 2013; Gao et al., 2019; Zhu-Barker et al., 2019) with SDI for horticultural crops (table 4) are discussed later in this article, and this topic will probably have more emphasis in the future with increasing concerns about climate change.

A large proportion of the SDI land area in Texas is devoted to cotton and with dry soil surface conditions often prevalent, cotton fields can be prone to wind erosion. Tillage and/or cover crop strategies appropriate for SDI would be useful in reducing this vulnerability. Adoption of no tillage with or without cover crop for cotton production resulted in significantly greater net returns (NR) than conventional tillage and numerically greater NR than reduced tillage on a clay loam soil (DeLaune et al., 2012). In a later study concerning the same research plots for the period 2013 through 2018, SDI cotton yields with no tillage and a terminated cover crop were $10 \%$ greater than with conventional tillage (DeLaune et al., 2020).

\section{SDI AS AN EFFICIENT OR CONVENIENT IRRIGATION SYSTEM FOR COTTON}

Fourteen studies primarily used SDI as an efficient or convenient irrigation system (table 2). As discussed earlier, it can be argued whether these studies should be included in the listing, so the discussion here is somewhat curtailed. However, characterizing the major focus areas might be worthwhile. Five studies incorporated SDI cotton into evaluations of combined cropping/livestock enterprises (Allen et al., 2012; Zilverberg et al., 2012; Johnson et al., 2013; Li et al., 2013; Zilverberg et al., 2014). Another four studies primarily used SDI to examine specific cotton cultivar responses (Snowden et al., 2013a, 2013b, 2014; Burke and Ulloa, 2017). This is somewhat analogous to what has been observed anecdotally around the U.S., i.e., that commercial seed companies use SDI on small road side parcels to exhibit crop hybrid or variety performance. Other reasons to use SDI included developing water management procedures (Rajan et al., 2010; Attia et al., 2016; Pabuayon et al., 2019), evaluating plant water stress (Chastain et al., 2016b), and evaluating crop response to biochar (Sorensen and Lamb, 2016). 


\section{Grain AND OILSEED CROPS}

Thirty-eight studies involving grain and oil seed crops were found in the review process (table 3 ) spread across the four subcategories.

\section{SDI IN COMPARISON TO ALTERNATIVE IRRIGATION SYSTEMS FOR GRAIN AND OILSEED CROPS}

Ten studies (table 3) compared SDI to alternative irrigation systems, primarily in the Great Plains region with CP systems. In eight of the ten studies, SDI had at least some benefit for grain and oilseed crops, and in two studies it did not.

Only four studies reported crop yields, and the benefits of SDI were either mixed results (Grabow et al., 2011; Lamm, 2016; Evett et al., 2019) or did not exist (Sorensen et al., 2012). This corresponds reasonably well with the results presented by Lamm (2016) summarizing 12 studies and finding an average of only $3 \%$ corn yield increase with SDI over alternative irrigation systems. In a study on a Pullman clay soil in Texas (Evett et al., 2019), SDI increased corn grain yield by $18 \%$ and WP by $28 \%$, but decreased grain sorghum yield by $12 \%$ and only increased WP by $4 \%$ as compared to MESA sprinkler irrigation. In a study on a Piedmont clay loam soil in North Carolina (Grabow et al., 2011), average SDI corn and soybean yields were not significantly different from SprI, but yields for both crops during the initial year were greatly reduced, possibly due to soil fracturing during the SDI system installation. SDI corn yields were similar to those obtained with DI in a fertigation study in Georgia (Sorensen et al., 2012).

Anecdotally, producers often report that they obtain greater yields with SDI than with alternative systems, but that may be related to the different management of research plots and commercial farms (i.e., more uniform management in research for all systems, and SDI inherently allowing producers a greater level of crop management). Additional anecdotal evidence that is difficult to quantify in research plots includes producers' claims that SDI results in less weed and pest incidence compared with SprI, resulting in less chemical inputs and thus improved economics. A spreadsheet template (Lamm et al., 2015) allows users to compare their corn cropping economics for SDI and CP. The results are sensitive to field size and SDI system longevity, with improvement to SDI economic competitiveness for smaller field sizes and increased longevity.

Table 3. Identified SDI research studies in the U.S. concerning grain and oil seed crops, 2010 through 2020.

\begin{tabular}{|c|c|c|c|c|c|c|c|c|c|}
\hline \multirow[b]{2}{*}{ Study } & \multirow[b]{2}{*}{$\begin{array}{c}\text { Highlights and Other Reported } \\
\text { Factors or Data } \\
\end{array}$} & \multirow[b]{2}{*}{$\begin{array}{l}\text { Study } \\
\text { Type }\end{array}$} & \multirow{2}{*}{$\begin{array}{l}\text { U.S. State } \\
\text { and/or } \\
\text { Region }\end{array}$} & \multirow[b]{2}{*}{$\begin{array}{l}\text { Soil } \\
\text { Type }\end{array}$} & \multicolumn{2}{|c|}{ Driplines $^{[a]}$} & \multirow{2}{*}{$\begin{array}{l}\text { No. of } \\
\text { Water } \\
\text { Levels }\end{array}$} & \multirow[b]{2}{*}{$\begin{array}{l}\text { Crop } \\
\text { Yield }\end{array}$} & \multirow[b]{2}{*}{$\begin{array}{c}\text { SDI } \\
\text { Benefit }\end{array}$} \\
\hline & & & & & $\begin{array}{l}\text { Depth } \\
(\mathrm{m})\end{array}$ & $\begin{array}{l}\text { Spacing } \\
(\mathrm{m})\end{array}$ & & & \\
\hline \multicolumn{10}{|c|}{ Studies comparing SDI to alternative irrigation systems and also possibly to dryland production or possibly to improve SDI performance } \\
\hline $\begin{array}{l}\text { Diotto and } \\
\text { Irmak, } 2016\end{array}$ & $\begin{array}{l}\text { SDI corn had } 43 \% \text { and } 29 \% \text { greater } \\
\text { energy return on investment than } \\
\text { FI and SprI, respectively. }\end{array}$ & Modeling & $\begin{array}{l}\text { Nebraska } \\
(\mathrm{MW})\end{array}$ & NA & NA & NA & 9 & No & Yes \\
\hline $\begin{array}{l}\text { Evett et al., } \\
2019\end{array}$ & $\begin{array}{l}\text { SDI benefitted corn but not grain sorghum } \\
\text { compared to MESA. Other: WP. }\end{array}$ & Field & $\begin{array}{l}\text { Texas } \\
\text { (SW) }\end{array}$ & Clay loam & $\begin{array}{c}0.30 \text { to } \\
0.36\end{array}$ & 1.5 & 4 & Yes & $\begin{array}{l}\text { Mixed } \\
\text { results }\end{array}$ \\
\hline $\begin{array}{c}\text { Evett et al., } \\
2020 \mathrm{a}\end{array}$ & $\begin{array}{c}K_{c} \text { values for corn were } 10 \% \text { less } \\
\text { with SDI than for MESA. }\end{array}$ & Field & $\begin{array}{l}\text { Texas } \\
\text { (SW) }\end{array}$ & Clay loam & $\begin{array}{c}0.30 \text { to } \\
0.36\end{array}$ & 1.5 & 4 & No & Yes \\
\hline $\begin{array}{c}\text { Grabow et al., } \\
2011\end{array}$ & $\begin{array}{l}\text { SDI yields for corn and soybean increased } \\
\text { in later years, possibly due to soil } \\
\text { consolidation. Other: Dryland; SprI. }\end{array}$ & Field & $\begin{array}{l}\text { North } \\
\text { Carolina } \\
\text { (SE) }\end{array}$ & Clay loam & 0.3 & $\begin{array}{l}1.5 \text { or } \\
2.3\end{array}$ & 2 & Yes & $\begin{array}{l}\text { Mixed } \\
\text { results }\end{array}$ \\
\hline $\begin{array}{l}\text { Irmak et al., } \\
2011\end{array}$ & $\begin{array}{l}\text { Ratio of soil heat flux to net radiation } \\
\text { of SDI was less than for SprI for corn } \\
\text { and soybean. Other: Dryland. }\end{array}$ & Field & $\begin{array}{l}\text { Nebraska } \\
\text { (MW) }\end{array}$ & Silt loam & 0.4 & 1.52 & NA & No & Yes \\
\hline $\begin{array}{l}\text { Lamm et al., } \\
2015\end{array}$ & $\begin{array}{l}\text { Spreadsheet template presented to evaluate } \\
\text { SDI and CP economics for corn. }\end{array}$ & Software & $\begin{array}{l}\text { Great } \\
\text { Plains }\end{array}$ & Silt loam & NA & NA & NA & No & $\begin{array}{l}\text { Mixed } \\
\text { results }\end{array}$ \\
\hline Lamm, 2016 & $\begin{array}{l}\text { Adoption of SDI for corn seemed more } \\
\text { related to increasing irrigated area. } \\
\text { Other: DI, SGI, SprI; Fertigation; } \\
\text { Cotton, tomato, and onion. }\end{array}$ & $\begin{array}{l}\text { Review/ } \\
\text { Summary }\end{array}$ & $\begin{array}{l}\text { Not limited } \\
\text { to U.S. }\end{array}$ & NA & Various & Various & Various & Yes & $\begin{array}{l}\text { Mixed } \\
\text { results }\end{array}$ \\
\hline $\begin{array}{l}\text { Odhiambo and } \\
\text { Irmak, } 2015\end{array}$ & $\begin{array}{l}\text { SDI had } 10 \% \text { less evaporative losses } \\
\text { as compared to SprI for soybean. }\end{array}$ & Field & $\begin{array}{c}\text { Nebraska } \\
\text { (MW) }\end{array}$ & Silt loam & 0.4 & 1.5 & 1 & No & Yes \\
\hline $\begin{array}{l}\text { Skaggs and } \\
\text { Irmak, } 2011\end{array}$ & $\begin{array}{l}\text { Nighttime ET and flux differences } \\
\text { for soybean were not much different } \\
\text { between SDI and SprI. }\end{array}$ & Field & $\begin{array}{l}\text { Nebraska } \\
\text { (MW) }\end{array}$ & NA & 0.4 & 1.5 & 1 & No & No \\
\hline $\begin{array}{c}\text { Sorensen } \\
\text { et al., } 2012 \\
\end{array}$ & $\begin{array}{l}\text { SDI and DI corn yields were similar for } \\
\text { similar fertigation levels. Other: Economics. }\end{array}$ & Field & $\begin{array}{c}\text { Georgia } \\
(\mathrm{SE})\end{array}$ & $\begin{array}{c}\text { Sandy } \\
\text { loam }\end{array}$ & 0.3 & $\begin{array}{c}0.9 \text { and } \\
1.8\end{array}$ & 1 & Yes & No \\
\hline \multicolumn{10}{|c|}{ Studies comparing SDI to dryland production and possibly to improve an aspect of SDI performance } \\
\hline $\begin{array}{l}\text { Jordan et al., } \\
\quad 2014\end{array}$ & $\begin{array}{l}\text { Economics for corn for SDI was justified } \\
\text { but only in } 50 \% \text { of years for cotton and } \\
\text { peanut. Other: Dryland; Economics. }\end{array}$ & Field & $\begin{array}{l}\text { North } \\
\text { Carolina } \\
\text { (SE) }\end{array}$ & $\begin{array}{l}\text { Sandy } \\
\text { loam }\end{array}$ & 0.25 & 0.91 & 2 & Yes & $\begin{array}{l}\text { Mixed } \\
\text { results }\end{array}$ \\
\hline $\begin{array}{l}\text { Sorensen } \\
\text { et al., } 2010 \mathrm{~b}\end{array}$ & $\begin{array}{l}\text { NR for shallow } \mathrm{S}^{3} \mathrm{DI} \text { replaced annually } \\
\text { was sufficient for cotton and corn, but } \\
\text { not peanut. Other: Economics. }\end{array}$ & Field & $\begin{array}{l}\text { Georgia } \\
\text { (SE) }\end{array}$ & $\begin{array}{l}\text { Fine sandy } \\
\text { loam }\end{array}$ & 0.05 & 1.8 & 1 & Yes & $\begin{array}{l}\text { Mixed } \\
\text { results }\end{array}$ \\
\hline $\begin{array}{l}\text { Sorensen } \\
\text { et al., } 2016\end{array}$ & $\begin{array}{l}\text { Shallow } \mathrm{S}^{3} \mathrm{DI} \text { replaced every } 3 \text { years } \\
\text { was economical in this region for cotton, } \\
\text { corn, and peanut compared to dryland. }\end{array}$ & Field & $\begin{array}{l}\text { Georgia } \\
\text { (SE) }\end{array}$ & $\begin{array}{l}\text { Fine sandy } \\
\text { clay loam }\end{array}$ & 0.03 & 1.8 & 2 & Yes & Yes \\
\hline $\begin{array}{c}\text { van Donk et al., } \\
2012\end{array}$ & $\begin{array}{l}\text { Corn yield increased for SDI over rainfed, } \\
\text { but not much effect of timing. Other: WP. }\end{array}$ & Field & $\begin{array}{l}\text { Nebraska } \\
\text { (MW) }\end{array}$ & Silt loam & 0.4 & 1.5 & 8 & Yes & Yes \\
\hline
\end{tabular}


Table 3 (continued). Identified SDI research studies in the U.S. concerning grain and oil seed crops, 2010 through 2020.

\begin{tabular}{|c|c|c|c|c|c|c|c|c|c|}
\hline \multirow[b]{2}{*}{ Study } & \multirow[b]{2}{*}{$\begin{array}{c}\text { Highlights and Other Reported } \\
\text { Factors or Data } \\
\end{array}$} & \multirow[b]{2}{*}{$\begin{array}{l}\text { Study } \\
\text { Type }\end{array}$} & \multirow{2}{*}{$\begin{array}{l}\text { U.S. State } \\
\text { and/or } \\
\text { Region } \\
\end{array}$} & \multirow[b]{2}{*}{$\begin{array}{c}\text { Soil } \\
\text { Type }\end{array}$} & \multicolumn{2}{|c|}{ Driplines $^{[\mathrm{a}]}$} & \multirow{2}{*}{$\begin{array}{l}\text { No. of } \\
\text { Water } \\
\text { Levels }\end{array}$} & \multirow[b]{2}{*}{$\begin{array}{l}\text { Crop } \\
\text { Yield }\end{array}$} & \multirow[b]{2}{*}{$\begin{array}{c}\text { SDI } \\
\text { Benefit }\end{array}$} \\
\hline & & & & & $\begin{array}{l}\text { Depth } \\
(\mathrm{m})\end{array}$ & $\begin{array}{l}\text { Spacing } \\
(\mathrm{m})\end{array}$ & & & \\
\hline \multicolumn{10}{|c|}{ Studies attempting to evaluate a response specifically for SDI or to improve SDI performance } \\
\hline $\begin{array}{l}\text { Arbat et al., } \\
2010\end{array}$ & $\begin{array}{c}\text { Corn yield and WP were not affected by } \\
\text { emitter spacing. Other: Two-dimensional } \\
\text { soil water distribution profiles. }\end{array}$ & Field & $\begin{array}{c}\text { Kansas } \\
\text { (MW) }\end{array}$ & Silt loam & 0.33 & 1.5 & 1 & Yes & NA \\
\hline $\begin{array}{l}\text { Chatterjee } \\
\text { et al., } 2019 \text {; } \\
\text { Irmak et al., } \\
2014 \mathrm{a}\end{array}$ & $\begin{array}{l}\text { Eddy covariance energy balance } \\
\text { reported for SDI corn. Note that the } \\
2019 \text { article corrects the } 2014 \text { article. }\end{array}$ & Field & $\begin{array}{l}\text { Nebraska } \\
\text { (MW) }\end{array}$ & Silt loam & 0.4 & 1.5 & 1 & No & NA \\
\hline $\begin{array}{c}\text { Eltarabily } \\
\text { et al., 2019b }\end{array}$ & $\begin{array}{c}\text { A reduction in } \mathrm{N} \text { uptake for sunflower } \\
\text { was modeled for deficit irrigation. } \\
\text { Other: Fertigation. }\end{array}$ & $\begin{array}{l}\text { Modeling } \\
\text { /Field }\end{array}$ & $\begin{array}{l}\text { California } \\
\text { (W) }\end{array}$ & $\begin{array}{l}\text { Silty clay } \\
\text { loam }\end{array}$ & 0.3 & 0.75 & 2 & NA & NA \\
\hline $\begin{array}{c}\text { Eltarabily } \\
\text { et al., } 2020\end{array}$ & $\begin{array}{c}\text { Some saline groundwater uptake by } \\
\text { sunflower was tolerable with deficit SDI. }\end{array}$ & Field & $\begin{array}{l}\text { California } \\
\text { (W) }\end{array}$ & $\begin{array}{c}\text { Silty clay } \\
\text { loam }\end{array}$ & 0.3 & 0.75 & 4 & Yes & Yes \\
\hline $\begin{array}{l}\text { Irmak and } \\
\text { Djaman, } \\
2016\end{array}$ & $\begin{array}{c}\text { Overall SDI corn grain yield responded } \\
\text { favorably to greater plant density. } \\
\text { Other: WP. }\end{array}$ & Field & $\begin{array}{l}\text { Nebraska } \\
\text { (MW) }\end{array}$ & Silt loam & 0.4 & 1.52 & 11 & Yes & Yes \\
\hline $\begin{array}{l}\text { Irmak et al., } \\
2014 \mathrm{~b}\end{array}$ & $\begin{array}{c}\text { Delaying SDI to growth stage R3 } \\
\text { of soybeans was beneficial. } \\
\text { Other: Fertigation; WP. }\end{array}$ & Field & $\begin{array}{l}\text { Nebraska } \\
\text { (MW) }\end{array}$ & Silt loam & 0.4 & 1.52 & 11 & Yes & $\begin{array}{l}\text { Mixed } \\
\text { results }\end{array}$ \\
\hline $\begin{array}{l}\text { Irmak et al., } \\
2016\end{array}$ & $\begin{array}{l}\text { Generally, } 75 \% \text { to } 100 \% \text { of full irrigation } \\
\text { was optimal, and there was no effect of } \\
\text { SDI frequency for corn. Other: WP. }\end{array}$ & Field & $\begin{array}{l}\text { Nebraska } \\
\text { (MW) }\end{array}$ & Silt loam & 0.4 & 1.52 & 5 & Yes & Yes \\
\hline $\begin{array}{c}\text { Lamm and } \\
\text { Rogers, } 2017\end{array}$ & $\begin{array}{l}\text { SDI system life of } 26.5 \text { years for } \\
\text { corn reported with good uniformity. }\end{array}$ & Field & $\begin{array}{c}\text { Kansas } \\
\text { (MW) }\end{array}$ & Silt loam & $\begin{array}{c}0.40 \text { to } \\
0.45\end{array}$ & 1.5 & NA & Yes & NA \\
\hline $\begin{array}{l}\text { Lamm et al., } \\
2010\end{array}$ & $\begin{array}{c}\text { Dripline depths of } 0.2 \text { to } 0.6 \mathrm{~m} \text { were } \\
\text { adequate for sunflower, soybean, } \\
\text { and grain sorghum. Other: WP. }\end{array}$ & Field & $\begin{array}{l}\text { Kansas } \\
\text { (MW) }\end{array}$ & Silt loam & $\begin{array}{l}0.2,0.3 \\
0.4,0.5 \\
\text { or } 0.6 \mathrm{~m}\end{array}$ & 1.5 & 1 & Yes & NA \\
\hline $\begin{array}{l}\text { Murley et al., } \\
2018\end{array}$ & $\begin{array}{c}\text { Dripline offset of up to } 0.38 \mathrm{~m} \text { did } \\
\text { not affect corn and grain sorghum } \\
\text { yield. Other: Fertigation. }\end{array}$ & Field & $\begin{array}{l}\text { Oklahoma } \\
\text { (SW) }\end{array}$ & Clay loam & 0.3 & 1.5 & 3 & Yes & NA \\
\hline $\begin{array}{l}\text { Odhiambo and } \\
\text { Irmak, } 2011\end{array}$ & $\begin{array}{l}\text { Model to partition ET had mixed } \\
\text { performance for soybean at } \\
\text { different growth stages. }\end{array}$ & Field & $\begin{array}{l}\text { Nebraska } \\
\text { (MW) }\end{array}$ & Silt loam & 0.4 & 1.5 & 1 & No & NA \\
\hline Sorensen, 2019 & $\begin{array}{l}\text { Peanut foliage removal above shallow } \\
\text { driplines decreased rodent damage. }\end{array}$ & Field & $\begin{array}{c}\text { Georgia } \\
\text { (SE) }\end{array}$ & $\begin{array}{c}\text { Loamy sand, } \\
\text { sandy loam }\end{array}$ & 0.05 & 1.8 & 1 & Yes & NA \\
\hline $\begin{array}{l}\text { Sorensen and } \\
\text { Butts, } 2014\end{array}$ & $\begin{array}{l}\text { SDI with } 75 \% \text { full irrigation was } \\
\text { sufficient, and } 0.9 \text { m dripline spacing } \\
\text { may not be justified for peanut. }\end{array}$ & Field & $\begin{array}{l}\text { Georgia } \\
\text { (SE) }\end{array}$ & $\begin{array}{l}\text { Sandy } \\
\text { loam }\end{array}$ & 0.3 & $\begin{array}{l}0.9 \text { and } \\
1.8\end{array}$ & 3 & Yes & NA \\
\hline $\begin{array}{l}\text { Sorensen and } \\
\text { Lamb, } 2015\end{array}$ & $\begin{array}{c}\text { Longevity for shallow } \mathrm{S}^{3} \mathrm{DI} \text { was estimated } \\
\text { to be economically } 5.4 \text { years. Other: } \\
\text { Economics; Cotton, corn, and peanut. }\end{array}$ & Field & $\begin{array}{l}\text { Georgia } \\
\text { (SE) }\end{array}$ & $\begin{array}{l}\text { Fine sandy } \\
\text { loam }\end{array}$ & 0.038 & 1.8 & 1 & Yes & NA \\
\hline $\begin{array}{l}\text { Sorensen } \\
\text { et al., } 2013\end{array}$ & $\begin{array}{l}\text { SDI with } 75 \% \text { full irrigation was sufficient } \\
\text { for corn, and no yield difference for } \\
\text { dripline spacing. Other: Fertigation. }\end{array}$ & Field & $\begin{array}{l}\text { Georgia } \\
\text { (SE) }\end{array}$ & $\begin{array}{l}\text { Sandy } \\
\text { loam }\end{array}$ & $\begin{array}{c}0.31 \text { to } \\
0.36\end{array}$ & $\begin{array}{l}0.9 \text { and } \\
1.8\end{array}$ & 3 & Yes & NA \\
\hline $\begin{array}{l}\text { Spurgeon and } \\
\text { Yonts, } 2013\end{array}$ & $\begin{array}{l}\text { Corn yield similar at } 100 \% \text { and } 125 \% \text { of } \\
\text { full irrigation, but no differences in dry } \\
\text { bean yield down to } 50 \% \text { irrigation. }\end{array}$ & Field & $\begin{array}{l}\text { Nebraska } \\
\text { (MW) }\end{array}$ & $\begin{array}{l}\text { Very fine } \\
\text { sandy loam }\end{array}$ & 0.28 & 1.1 & 4 & Yes & Yes \\
\hline \multicolumn{10}{|c|}{ Studies primarily using SDI as an efficient or convenient irrigation system } \\
\hline $\begin{array}{c}\text { Barnaby et al., } \\
2019 \\
\end{array}$ & $\begin{array}{c}\text { Rice cultivars use different strategies } \\
\text { to handle water stress. }\end{array}$ & Field & $\begin{array}{c}\text { Arkansas } \\
(\mathrm{MW})\end{array}$ & Silt loam & NA & NA & 4 & Yes & NA \\
\hline $\begin{array}{l}\text { Kukal and } \\
\text { Irmak, } 2020\end{array}$ & $\begin{array}{c}\text { Water use and WP compared for corn, } \\
\text { sorghum, soybean, and wheat } \\
\text { were reported. Other: WP. }\end{array}$ & Field & $\begin{array}{l}\text { Nebraska } \\
\text { (MW) }\end{array}$ & Silt loam & NA & NA & NA & No & NA \\
\hline $\begin{array}{l}\text { Pabuayon } \\
\text { et al., } 2019\end{array}$ & $\begin{array}{l}\text { Biomass and yield of cotton and grain } \\
\text { sorghum increased under irrigation } \\
\text { but not for sesame. Other: WP; cotton. }\end{array}$ & Field & $\begin{array}{l}\text { Texas } \\
(\mathrm{SW})\end{array}$ & Clay loam & NA & NA & 4 & Yes & NA \\
\hline $\begin{array}{l}\text { Sandhu and } \\
\text { Irmak, } 2019\end{array}$ & $\begin{array}{c}\text { Overestimation of corn yield and } \\
\text { underestimation of ET with } \\
\text { AquaCrop. Other: WP. }\end{array}$ & $\begin{array}{l}\text { Modeling } \\
\text { /Field }\end{array}$ & $\begin{array}{l}\text { Nebraska } \\
(\mathrm{MW})\end{array}$ & Silt loam & 0.4 & 1.5 & 1 & Yes & NA \\
\hline $\begin{array}{c}\text { Sorensen and } \\
\text { Lamb, } 2016\end{array}$ & $\begin{array}{l}\text { Crop response to biochar rate minimal. } \\
\text { Other: Cotton, corn, and peanut. }\end{array}$ & Field & $\begin{array}{c}\text { Georgia } \\
(\mathrm{SE})\end{array}$ & $\begin{array}{l}\text { Fine sandy } \\
\text { loam }\end{array}$ & 0.05 & NA & 1 & Yes & NA \\
\hline $\begin{array}{l}\text { Sorensen and } \\
\text { Nuti, } 2011\end{array}$ & $\begin{array}{l}\text { Selenium application for peanut might } \\
\text { be beneficial but might not } \\
\text { be cost-effective. }\end{array}$ & Field & $\begin{array}{l}\text { Georgia } \\
\text { (SE) }\end{array}$ & $\begin{array}{l}\text { loamy sand, } \\
\text { fine sandy } \\
\text { clay loam }\end{array}$ & 0.3 & 0.9 & 1 & Yes & NA \\
\hline $\begin{array}{c}\text { Sorensen } \\
\text { et al., } 2010 \mathrm{a} \\
\end{array}$ & $\begin{array}{l}\text { Tillage, cover crops, peanut cultivars, } \\
\text { and fungicides were evaluated. }\end{array}$ & Field & $\begin{array}{c}\text { Georgia } \\
\text { (SE) }\end{array}$ & $\begin{array}{c}\text { Sandy } \\
\text { loam }\end{array}$ & 0.3 & 0.9 & 1 & Yes & NA \\
\hline
\end{tabular}

[a] Multiple dripline depths and spacings separated by "to" denote a range, by "and" denote a non-experimental factor, and by "or" denote an experimental factor. Abbreviations are listed in table 1. 
Four studies that did not report crop yields did report SDI benefits as compared to SprI. The reported benefits included a greater energy return on investment for corn (Diotto and Irmak, 2016), a $10 \%$ reduction in crop coefficients $\left(K_{c}\right)$ for corn (Evett et al., 2020a), a reduction in the ratio of soil heat flux to net radiation for corn and soybean (Irmak et al., 2011), and less evaporative losses for soybean (Odhiambo and Irmak, 2015). However, in another study in Nebraska, nighttime ET and flux differences for soybean were reported as similar for SDI and SprI (Skaggs and Irmak, 2011).

\section{SDI IN COMPARISON TO DRYLAND PRODUCTION FOR GRAIN AND OILSEED CROPS}

Four studies compared SDI to dryland production (table 3 spanning the upper two subcategories) and in all cases resulted in crop yield increases (corn and soybean for Grabow et al., 2011; cotton, corn, and peanut for Jordan et al., 2014, and Sorensen et al., 2010b, 2016; and corn for van Donk et al., 2012). Although Jordan et al. (2014) reported yield increases with SDI over dryland production for all three crops, the economic viability of SDI for cotton and peanut was less favorable than for corn. A discussion of $S^{3} \mathrm{DI}$ and the Sorensen et al. (2010b, 2016) studies is included in the Cotton section of this article and is not repeated here.

\section{STUdies of SDI Responses ANd/OR Performance IMPROVEMENTS FOR GRAIN AND OILSEED CROPS}

Twenty studies were related to this subcategory (table 3), including Evett et al. (2020a) from the upper subcategory (i.e., improving SDI $K_{c}$ values), Sorensen et al. (2010b, 2016) (i.e., evaluating $S^{3} D I$ ), and van Donk et al. (2012) from the preceding section.

Design aspects of SDI were evaluated by Arbat et al. (2010), Lamm et al. (2010), Sorensen and Butts (2014), Sorensen et al. (2013), and Murley et al. (2018). SDI emitter spacings ranging from 0.3 to $1.2 \mathrm{~m}$ did not significantly affect corn yield nor WP on a deep silt loam soil in Kansas (Arbat et al., 2010). In another Kansas study at the same location, dripline depths ranging from 0.2 to $0.6 \mathrm{~m}$ were deemed to be adequate for sunflower, soybean, and grain sorghum under conditions when crop establishment was not a problem (Lamm et al., 2010). Dripline spacings of 0.9 and $1.8 \mathrm{~m}$ gave similar corn yields (Sorensen et al., 2013) and generally gave similar yields for peanut (Sorensen and Butts, 2014) on a sandy loam soil in Georgia, and the wider spacing was recommended to reduce SDI system costs. Although proper alignment of crop rows and driplines is often deemed beneficial when using alternate-row middle dripline spacing (i.e., one dripline centered between alternate paired crop rows), a study in Oklahoma on a clay loam soil found that crop row offsets of up to $0.38 \mathrm{~m}$ from centered placement did not significantly affect overall corn or grain sorghum yields (Murley et al., 2018).

A number of studies (table 3) evaluated irrigation management strategies for SDI. A study on a silt loam soil in Nebraska found little difference in corn yield when irrigated at $75 \%$ of full irrigation and very little effect of four different timing strategies (van Donk et al., 2012). Another Nebraska study (Irmak et al., 2016) found similarly that $75 \%$ to $100 \%$ of full irrigation generally resulted in optimal corn yield. The researchers also reported that SDI frequency did not significantly affect corn yield. The management of corn planting date and plant density when coupled with SDI was evaluated by Irmak and Djaman (2016). They reported that plant density of 74,100 plants ha ${ }^{-1}$ or greater increased yields, but they had mixed results on planting date recommendations. In far western, semi-arid Nebraska on a very fine sandy loam soil, SDI corn yields were significantly greater at $100 \%$ or $125 \%$ of full irrigation in three of four years, but dry bean yields were generally not affected by SDI levels ranging from $50 \%$ to $125 \%$ (Spurgeon and Yonts, 2013). Corn yields (Sorensen et al., 2013) and peanut yields (Sorensen and Butts, 2014) on a sandy loam soil in Georgia were not significantly different for $75 \%$ and $100 \%$ of full irrigation. In a soybean study on a silt loam soil in Nebraska, it was determined that SDI could be delayed until the R3 growth stage (i.e., beginning of pods) without reducing yield or WP. In the low desert region of California for SDI sunflower, it was concluded that up to a $35 \%$ deficit irrigation regime supplemented with saline groundwater uptake would have less than a $20 \%$ reduction in yield (Eltarabily et al., 2020).

Three studies sought to evaluate or improve SDI system longevity. The economic longevity of $\mathrm{S}^{3} \mathrm{DI}$ was estimated to be approximately 5.4 years (i.e., cost to repair leaks equal to replacement cost) by Sorensen and Lamb (2015) for a cottoncorn-peanut rotation in Georgia. Further work at this location to improve $\mathrm{S}^{3} \mathrm{DI}$ longevity found that removal of peanut foliage above the dripline greatly decreased the amount of rodent damage without reducing peanut yield or grade (Sorensen, 2019). Removal of residue with tillage has also been anecdotally reported to reduce rodent damage to driplines in many other regions of the U.S. A much deeper ( 0.40 to $0.45 \mathrm{~m}$ ) SDI system on a deep silt loam soil in Kansas had a system life of 26.5 years without replacement (Lamm and Rogers, 2017). The researchers reported the lower quartile distribution uniformity at the end of the system life to be 96 to 97 (sometimes expressed as a percentage or fraction, such as $96 \%$ or 0.96 ) and that the overall reason for system abandonment was breakdown of the plastic material used in the driplines. An additional discussion of SDI longevity is included in the later section concerning studies with no specific crop and in table 7, specifically the Enciso et al. (2011) study.

The energy balance for SDI corn was investigated by Irmak et al. (2014a) and Chatterjee et al. (2019) using an eddy covariance system. They concluded that challenges remain in using these measurements for irrigation management. Partitioning of ET for soybean with SDI using the Shuttleworth-Wallace model was reported by Odhiambo and Irmak (2011), who found mixed performance depending on the soybean growth stage.

Experimental determination and modeling (Hydrus 2D) of SDI sunflower $\mathrm{N}$ uptake was conducted in California on a silty clay loam (Eltarabily et al., 2019b), and it was concluded that opportunities exist to reduce fertilizer application when deficit irrigation is anticipated to occur.

\section{SDI AS AN EFFICIENT OR CONVENIENT IRRIGATION SYSTEM FOR GRAIN AND OILSEED CROPS}

Seven studies were listed in this subcategory (table 3 ). Topic areas were water stress or water management 
evaluations (Pabuayon et al., 2019; Sandhu and Irmak, 2019; Kukal and Irmak, 2020), cultivar response (Sorensen et al., 2010a; Barnaby et al., 2019), agrochemical application (Sorensen et al., 2010a; Sorensen and Nuti, 2011; Sorensen and Lamb, 2016), and tillage and cover crops (Sorensen et al., 2010a).

\section{Horticultural CROPS}

Forty studies involving horticultural crops were found in the review process (table 4) spread across three subcategories. There were no reported studies comparing SDI to dryland (i.e., the second of the four subcategories).

\section{SDI IN COMPARISON TO ALTERNATIVE IRRIGATION SYSTEMS FOR HORTICULTURAL CROPS}

There were 24 reported studies comparing SDI to alternative irrigation systems (table 4). Nine studies reported greater horticultural crop yields with SDI, while three studies reported similar yields and three studies reported lower yields (table 4). SDI and FI had similar watermelon yields, but SDI used $45 \%$ to $60 \%$ less water and had $45 \%$ to $75 \%$ greater WP in a study on a sandy clay loam in Texas (Fuentes et al., 2018).

Pomegranate yield and WP increased and there was less weed pressure with SDI compared to DI on a sandy loam soil in California (Ayars et al., 2017), and in general $\mathrm{N}$ uptake increased (Tirado-Corbalá et al., 2019). Although there were no differences in young pomegranate tree canopy size, fruit yield increased even in the early years of the study with SDI (Zhang et al., 2017). When using fertigation for pomegranate, SDI had much lower GHG emissions than DI (Gao et al., 2019).

Reductions in GHG emissions were also reported for tomato when using SDI (Kallenbach et al., 2010; Kennedy et al., 2013) and for several horticultural crops (Zhu-Barker et al., 2019) and as previously discussed for cotton (Bronson et al., 2018, and table 2 discussion).

Greater onion yield and size were reported in Texas (Enciso et al., 2015b) with SDI compared to FI, but non-significant differences were reported for the same factors in Oregon (Shock et al., 2015). In a review of SDI onion research, Lamm (2016) concluded that modest yield increases were possible but that there was more evidence for larger onion sizes with SDI. Improved irrigation efficiency and less nitrate leaching with SDI for onion compared to FI was reported in New Mexico on a loam soil (Sharma et al., 2012). An emerging topic area concerns the use of irrigation systems to control pathogen transfer to fruits and vegetables. In an onion study in Oregon on a silt loam soil, only a small fraction of Escherichia coli was transferred to the onion bulb when using either SDI or FI (Shock et al., 2016), and the researchers concluded that the risk of bacterial contamination was small.

The effect of partial root zone drying (PRD) on chile pepper production was compared in greenhouse studies in New Mexico (Sharma et al., 2015, 2017). PRD with DI and root divided compartments or PRD with SDI where water was separated vertically were both found to have similar production to the control treatment (regular DI), which had approximately $30 \%$ greater applied water.

A novel modification of SDI technology for wine grapes, termed direct root zone irrigation (DRZ), was introduced by Jacoby and Ma (2018). With DRZ, irrigation water is applied at a specified depth by emitters installed in vertical PVC pipes. DRZ has been shown to increase wine grape yield by $9 \%$ to $12 \%$ and WP by $9 \%$ to $11 \%$ compared to DI (Ma et al., 2020b). Some of the rationale for increased wine grape yield was attributed to greater photosynthesis and an altered root distribution with DRZ. Further developmental work demonstrated the potential of using remote sensing to select wine grape varieties for both DRZ and DI (Zúñiga-Espinoza et al., 2016).

Greater efficiency of irrigation water and less weed pressure, but similar tomato yields, were found for SDI and FI in a study in California (Schmidt et al., 2018). Similar tomato yields, but a $100 \%$ WP increase, were reported in another California study (Kallenbach et al., 2010). A tomato yield increase of $48 \%$ with SDI as compared to SprI was reported in another California study on a clay loam soil. Tomato yield increases of approximately $12 \%$ were reported for SDI compared to alternative systems in a review of 16 studies by Lamm (2016).

Reduced spinach yield was reported for SDI compared to SprI, but SDI had better downy mildew control in the low desert region of California (Montazar et al., 2019). The researchers concluded that there was a need for further developmental work to optimize spinach production when using SDI. Potato yield was less with SDI than with DI or seepage irrigation on sandy soils in Florida (Reyes-Cabrera et al., 2014), which was attributed to limited soil water capillarity for SDI-applied water (Reyes-Cabrera et al., 2016). Modeling with Hydrus 2D/3D has shown that a physical barrier below SDI can improve soil water redistribution for tomato and potato (El-Nesr et al., 2014).

Hydrus modeling was used in three horticultural studies to evaluate nitrate redistribution under SDI fertigation for onion (Eltarabily et al., 2019a), the recommended dripline depth for lettuce (Slack et al., 2017), and the wetting pattern of a novel ring-shaped emitter for use by small-scale farmers (Saefuddin et al., 2019).

\section{STUdies OF SDI RESPONSES AND/OR PERFORMANCE IMPROVEMENTS FOR HORTICULTURAL CROPS}

Fifteen studies sought to measure a specific response to SDI or to improve SDI performance (table 4 when including the three DRZ studies by Ma et al. $(2020 \mathrm{a}, 2020 \mathrm{~b})$ and Zúñiga-Espinoza et al. (2016) from the upper subcategory).

Root length density responded differently for three muskmelon cultivars under deficit SDI (50\% of full irrigation) on a silty clay loam soil in Texas (Sharma et al., 2014, 2018), increasing for one netted (reticulatus) cultivar, decreasing for another netted cultivar, and not affecting the third cultivar, which was a winter melon (honeydew; inordorus). Greater yield decreases were recorded for the honeydew cultivar (33\%) with deficit irrigation than for the netted melons ( $24 \%$ to $30 \%$ ), but overall melon quality tended to increase with deficit SDI. The researchers concluded that the two 
Table 4. Identified SDI research studies in the U.S. concerning horticultural crops, 2010 through 2020.

\begin{tabular}{|c|c|c|c|c|c|c|c|c|c|}
\hline \multirow[b]{2}{*}{ Study } & \multirow[b]{2}{*}{$\begin{array}{c}\text { Highlights and Other Reported } \\
\text { Factors or Data } \\
\end{array}$} & \multirow[b]{2}{*}{$\begin{array}{l}\text { Study } \\
\text { Type }\end{array}$} & \multirow{2}{*}{$\begin{array}{l}\text { U.S. State } \\
\text { and/or } \\
\text { Region } \\
\end{array}$} & \multirow[b]{2}{*}{$\begin{array}{c}\text { Soil } \\
\text { Type }\end{array}$} & \multicolumn{2}{|c|}{ Driplines ${ }^{[\mathrm{a}]}$} & \multirow{2}{*}{$\begin{array}{l}\text { No. of } \\
\text { Water } \\
\text { Levels }\end{array}$} & \multirow[b]{2}{*}{$\begin{array}{l}\text { Crop } \\
\text { Yield }\end{array}$} & \multirow[b]{2}{*}{$\begin{array}{c}\text { SDI } \\
\text { Benefi }\end{array}$} \\
\hline & & & & & $\begin{array}{c}\text { Depth } \\
(\mathrm{m})\end{array}$ & $\begin{array}{c}\text { Spacing } \\
(\mathrm{m})\end{array}$ & & & \\
\hline \multicolumn{10}{|c|}{ Studies comparing SDI to alternative irrigation systems and also possibly to dryland production or possibly to improve SDI performance } \\
\hline $\begin{array}{l}\text { Ayars et al., } \\
2017\end{array}$ & $\begin{array}{l}\text { Numerically greater pomegranate yield and } \\
\text { WP and observed less weed pressure with } \\
\text { SDI compared to DI. Other: Fertigation. }\end{array}$ & Field & $\begin{array}{l}\text { California } \\
\text { (W) }\end{array}$ & $\begin{array}{l}\text { Sandy } \\
\text { loam }\end{array}$ & $\begin{array}{l}0.50 \text { to } \\
0.55\end{array}$ & 2.2 & 1 & Yes & Yes \\
\hline $\begin{array}{l}\text { El-Nesr et al., } \\
2014\end{array}$ & $\begin{array}{c}\text { A physical barrier below SDI can improve } \\
\text { soil water redistribution for tomato } \\
\text { and potato }\end{array}$ & Modeling & NA & $\begin{array}{l}\text { Sand and } \\
\text { loam }\end{array}$ & $\begin{array}{l}0.15 \text { and } \\
0.25\end{array}$ & NA & 1 & No & NA \\
\hline $\begin{array}{c}\text { Enciso et al., } \\
2015 b\end{array}$ & $\begin{array}{l}\text { SDI doubled onion yields and generally } \\
\text { increased onion size over FI and used } \\
44 \% \text { less water. Other: Fertigation. }\end{array}$ & Field & $\begin{array}{l}\text { Texas } \\
\text { (SW) }\end{array}$ & $\begin{array}{l}\text { Silty clay } \\
\text { loam and } \\
\text { sandy clay } \\
\text { loam }\end{array}$ & 0.05 & 1.0 & 1 & Yes & Yes \\
\hline $\begin{array}{l}\text { Fuentes et al., } \\
2018\end{array}$ & $\begin{array}{l}\text { SDI and FI had similar watermelon yields, } \\
\text { but SDI used } 45 \% \text { to } 60 \% \text { less water } \\
\text { and had } 45 \% \text { to } 75 \% \text { greater WP. }\end{array}$ & Field & $\begin{array}{l}\text { Texas } \\
(\mathrm{SW})\end{array}$ & $\begin{array}{l}\text { Sandy clay } \\
\text { loam }\end{array}$ & 0.05 & 2.0 & 1 & Yes & Yes \\
\hline $\begin{array}{l}\text { Gao et al., } \\
2019\end{array}$ & $\begin{array}{c}\text { SDI had much lower GHG emissions } \\
\text { compared to DI for pomegranate. } \\
\text { Other: Fertigation. }\end{array}$ & Field & $\begin{array}{l}\text { California } \\
\text { (W) }\end{array}$ & $\begin{array}{l}\text { Sandy } \\
\text { loam }\end{array}$ & $\begin{array}{l}0.50 \text { to } \\
0.55\end{array}$ & 2.2 & 1 & No & Yes \\
\hline $\begin{array}{l}\text { Kallenbach } \\
\text { et al., } 2010\end{array}$ & $\begin{array}{c}\text { Potentially large reductions in GHG with } \\
\text { SDI compared with FI for tomato. Yields } \\
\text { were similar but SDI had } 100 \% \text { greater WP. }\end{array}$ & Field & $\begin{array}{l}\text { California } \\
\text { (W) }\end{array}$ & $\begin{array}{l}\text { Loam and } \\
\text { silt loam }\end{array}$ & 0.25 & 1.5 & 1 & Yes & Yes \\
\hline $\begin{array}{l}\text { Kennedy } \\
\text { et al., } 2013\end{array}$ & $\begin{array}{l}\text { An integrated system (SDI, reduced tillage, } \\
\text { and fertigation) for tomato reduced GHG } \\
\text { emissions compared to conventional FI. }\end{array}$ & Field & California & $\begin{array}{l}\text { Silty clay } \\
\text { loam }\end{array}$ & 0.23 & 1.5 & 1 & No & Yes \\
\hline Lamm, 2016 & $\begin{array}{l}\text { Rationale for adoption of SDI was } \\
\text { greater yield for processing tomato } \\
\text { and greater quality for onion. } \\
\text { Other: DI, SGI, and SprI; Fertigation. }\end{array}$ & $\begin{array}{l}\text { Review } \\
\text { /Summary }\end{array}$ & $\begin{array}{l}\text { Not limited } \\
\text { to U.S. }\end{array}$ & NA & Various & Various & Various & Yes & $\begin{array}{l}\text { Mixed } \\
\text { results }\end{array}$ \\
\hline $\begin{array}{l}\text { Ma et al., } \\
2020 \mathrm{a}\end{array}$ & $\begin{array}{c}\text { Greater photosynthesis and altered root } \\
\text { distribution for wine grapes } \\
\text { with DRZ than for DI. }\end{array}$ & Field & $\begin{array}{l}\text { Washington } \\
\text { (NW) }\end{array}$ & $\begin{array}{l}\text { Loamy } \\
\text { fine sand }\end{array}$ & 0.6 & 1.8 & 3 & No & Yes \\
\hline $\begin{array}{c}\text { Ma et al., } \\
2020 \mathrm{~b}\end{array}$ & $\begin{array}{l}\text { DRZ increased wine grape yield by } 9 \% \\
\text { to } 12 \% \text { and WP by } 9 \% \text { to } 11 \% \text { over DI. }\end{array}$ & Field & $\begin{array}{l}\text { Washington } \\
\text { (NW) }\end{array}$ & $\begin{array}{c}\text { Loamy } \\
\text { fine sand }\end{array}$ & 0.6 & 1.8 & 3 & Yes & Yes \\
\hline $\begin{array}{l}\text { Mitchell } \\
\text { et al., } 2014\end{array}$ & $\begin{array}{l}\text { SDI tomato yields were } 48 \% \text { greater with } \\
\text { SDI than with SprI. Other: Fertigation }\end{array}$ & Field & California & Clay loam & 0.3 & 1.5 & 1 & Yes & Yes \\
\hline $\begin{array}{l}\text { Montazar } \\
\text { et al., } 2019\end{array}$ & $\begin{array}{c}\text { SprI generally had better yield, but SDI had } \\
\text { better downy mildew control on spinach. } \\
\text { Other: Fertigation; Economics. }\end{array}$ & Field & $\begin{array}{l}\text { California } \\
\text { (W) }\end{array}$ & $\begin{array}{l}\text { Silty clay } \\
\text { loam }\end{array}$ & 0.04 & 2.0 & 1 & Yes & $\begin{array}{l}\text { Mixed } \\
\text { results }\end{array}$ \\
\hline $\begin{array}{c}\text { Reyes-Cabrera } \\
\text { et al., } 2014 \\
\end{array}$ & $\begin{array}{l}\text { Potato yields were less with SDI than } \\
\text { with DI and seepage irrigation. }\end{array}$ & Field & $\begin{array}{c}\text { Florida } \\
\text { (SE) }\end{array}$ & Sandy & 0.2 & 1.0 & 1 & Yes & No \\
\hline $\begin{array}{l}\text { Reyes-Cabrera } \\
\text { et al., } 2016\end{array}$ & $\begin{array}{c}\text { SDI had lower potato yields due to } \\
\text { limited soil water capillarity than } \\
\text { for DI and seepage irrigation. }\end{array}$ & Field & $\begin{array}{l}\text { Florida } \\
\text { (SE) }\end{array}$ & Sandy & 0.2 & 1.0 & 1 & Yes & No \\
\hline $\begin{array}{l}\text { Schmidt et al., } \\
2018\end{array}$ & $\begin{array}{l}\text { Greater irrigation water use efficiency, less } \\
\text { weed pressure, and similar yield for tomato } \\
\text { with SDI than for FI. Other: Fertigation. }\end{array}$ & Field & $\begin{array}{l}\text { California } \\
\text { (W) }\end{array}$ & NA & 0.25 & 1.5 & 1 & Yes & $\begin{array}{l}\text { Mixed } \\
\text { results }\end{array}$ \\
\hline $\begin{array}{l}\text { Sharma et al., } \\
2012\end{array}$ & $\begin{array}{c}\text { Improved irrigation efficiency and less } \\
\text { nitrate leaching with SDI for onion } \\
\text { compared to FI. }\end{array}$ & Field & $\begin{array}{l}\text { New Mexico } \\
\text { (SW) }\end{array}$ & Loam & 0.1 & 0.56 & 1 & No & Yes \\
\hline $\begin{array}{l}\text { Sharma et al., } \\
2015\end{array}$ & $\begin{array}{l}\text { PRD using either DI or SDI used } 30 \% \\
\text { less water without affecting plant water } \\
\text { stress, quality, or yield of chile pepper } \\
\text { compared with DI with no PRD. }\end{array}$ & Greenhouse & $\begin{array}{l}\text { New Mexico } \\
\text { (SW) }\end{array}$ & $\begin{array}{l}\text { Potted } \\
\text { mixed soil }\end{array}$ & 0.2 & NA & 1 & Yes & Yes \\
\hline $\begin{array}{l}\text { Sharma et al., } \\
2017\end{array}$ & $\begin{array}{l}\text { Water savings with PRD using DI or SDI } \\
\text { for chile pepper compared to DI without } \\
\text { PRD. } K_{c} \text { values were developed. }\end{array}$ & Greenhouse & $\begin{array}{l}\text { New Mexico } \\
\text { (SW) }\end{array}$ & $\begin{array}{l}\text { Potted } \\
\text { mixed soil }\end{array}$ & 0.2 & NA & 1 & No & NA \\
\hline $\begin{array}{c}\text { Shock et al., } \\
2015\end{array}$ & $\begin{array}{c}\text { In general, few differences in onion yield } \\
\text { between SDI and FI. Other: } \\
\text { Fertigation; Economics. }\end{array}$ & Field & $\begin{array}{l}\text { Oregon } \\
\text { (NW) }\end{array}$ & Silt loam & 0.1 & Variable & 1 & Yes & $\begin{array}{l}\text { Mixed } \\
\text { results }\end{array}$ \\
\hline $\begin{array}{c}\text { Shock et al., } \\
2016 \\
\end{array}$ & $\begin{array}{l}\text { Either FI or SDI was acceptable for } \\
\text { pathogen control in onion. }\end{array}$ & Field & $\begin{array}{c}\text { Oregon } \\
(\mathrm{NW})\end{array}$ & Silt loam & 0.07 & 1.12 & 1 & No & No \\
\hline $\begin{array}{l}\text { Tirado-Corbalá } \\
\text { et al., } 2019\end{array}$ & $\begin{array}{c}\text { SDI generally had greater pomegranate } \\
\text { yield and N uptake than DI. } \\
\text { Other: Fertigation. }\end{array}$ & Field & $\begin{array}{l}\text { California } \\
\text { (W) }\end{array}$ & $\begin{array}{l}\text { Sandy } \\
\text { loam }\end{array}$ & 0.55 & 2.0 & 1 & Yes & Yes \\
\hline $\begin{array}{c}\text { Zhang et al., } \\
2017 \\
\end{array}$ & $\begin{array}{l}\text { Greater pomegranate yield with SDI } \\
\text { than with DI. }\end{array}$ & Field & $\begin{array}{l}\text { California } \\
\text { (W) }\end{array}$ & $\begin{array}{c}\text { Sandy } \\
\text { loam }\end{array}$ & 0.5 & 4.9 & 4 & Yes & Yes \\
\hline $\begin{array}{l}\text { Zúñiga-Espinoza } \\
\text { et al., } 2016\end{array}$ & $\begin{array}{c}\text { Potential to use remote sensing to select } \\
\text { water-efficient wine grape varieties } \\
\text { under DI and DRZ irrigation. }\end{array}$ & Field & $\begin{array}{l}\text { Washington } \\
\text { (NW) }\end{array}$ & $\begin{array}{l}\text { Loamy } \\
\text { fine sand }\end{array}$ & $\begin{array}{l}0.3,0.6 \\
\text { and } 0.9\end{array}$ & 2.4 & 3 & Yes & NA \\
\hline
\end{tabular}


Table 4 (continued). Identified SDI research studies in the U.S. concerning horticultural crops, 2010 through 2020.

\begin{tabular}{|c|c|c|c|c|c|c|c|c|c|}
\hline \multirow[b]{2}{*}{ Study } & \multirow[b]{2}{*}{$\begin{array}{l}\text { Highlights and Other Reported } \\
\text { Factors or Data }\end{array}$} & \multirow[b]{2}{*}{$\begin{array}{l}\text { Study } \\
\text { Type }\end{array}$} & \multirow{2}{*}{$\begin{array}{c}\text { U.S. State } \\
\text { and/or } \\
\text { Region } \\
\end{array}$} & \multirow[b]{2}{*}{$\begin{array}{c}\text { Soil } \\
\text { Type }\end{array}$} & \multicolumn{2}{|c|}{ Driplines $^{[\mathrm{a}]}$} & \multirow{2}{*}{$\begin{array}{l}\text { No. of } \\
\text { Water } \\
\text { Levels }\end{array}$} & \multirow[b]{2}{*}{$\begin{array}{l}\text { Crop } \\
\text { Yield }\end{array}$} & \multirow[b]{2}{*}{$\begin{array}{c}\text { SDI } \\
\text { Benefit }\end{array}$} \\
\hline & & & & & $\begin{array}{l}\text { Depth } \\
(\mathrm{m})\end{array}$ & $\begin{array}{l}\text { Spacing } \\
(\mathrm{m})\end{array}$ & & & \\
\hline \multicolumn{10}{|c|}{ Studies attempting to evaluate a response specifically for SDI or to improve SDI performance } \\
\hline $\begin{array}{l}\text { Cabrera et al., } \\
2012\end{array}$ & $\begin{array}{l}\text { Fumigants were adequate with SDI but } \\
\text { less so than deep-shanked methyl } \\
\text { bromide for grape vines. }\end{array}$ & Field & $\begin{array}{l}\text { California } \\
\text { (W) }\end{array}$ & $\begin{array}{l}\text { Fine sandy } \\
\text { loam }\end{array}$ & $\begin{array}{l}0.05 \text { and } \\
0.25\end{array}$ & 0.6 & 1 & Yes & $\begin{array}{l}\text { Mixed } \\
\text { results }\end{array}$ \\
\hline $\begin{array}{l}\text { Chakraborty } \\
\text { et al., } 2019\end{array}$ & $\begin{array}{l}\text { No differences noted for three DRZ } \\
\text { levels for apple and grape vines, but } \\
\text { confounded by winter snowpack. }\end{array}$ & Field & $\begin{array}{l}\text { Washington } \\
\text { (NW) }\end{array}$ & NA & $\begin{array}{l}0.3,0.6 \\
\text { and } 0.9\end{array}$ & NA & 3 & NA & NA \\
\hline $\begin{array}{l}\text { Eltarabily } \\
\text { et al., 2019a }\end{array}$ & $\begin{array}{l}\text { Using Hydrus, nitrate redistribution was } \\
\text { mainly governed by soil type not emitter } \\
\text { discharge for SDI on onion. } \\
\text { Other: Fertigation. }\end{array}$ & Modeling & $\begin{array}{l}\text { California } \\
\text { (W) }\end{array}$ & $\begin{array}{l}\text { Sandy } \\
\text { loam, } \\
\text { silt loam, } \\
\text { and loam } \\
\end{array}$ & 0.1 & NA & 3 & NA & NA \\
\hline $\begin{array}{l}\text { Hunsaker } \\
\text { et al., } 2019\end{array}$ & $\begin{array}{c}\text { Guayule production with SDI could save } \\
\text { water, but better crop establishment } \\
\text { is needed with SDI. } \\
\text { Other: Fertigation; WP. }\end{array}$ & Field & $\begin{array}{l}\text { Arizona } \\
\text { (SW) }\end{array}$ & $\begin{array}{l}\text { Sandy } \\
\text { loam and } \\
\text { sandy } \\
\text { clay loam }\end{array}$ & 0.2 & 1.0 & 5 & Yes & NA \\
\hline $\begin{array}{l}\text { Jacoby and } \\
\text { Ma, } 2018\end{array}$ & $\begin{array}{l}\text { Brief introduction of DRZ with photos } \\
\text { and proof-of-concept discussion } \\
\text { of DRZ as a type of SDI. }\end{array}$ & Field & $\begin{array}{l}\text { Washington } \\
\text { (NW) }\end{array}$ & $\begin{array}{l}\text { Loamy } \\
\text { fine sand }\end{array}$ & $\begin{array}{l}0.3,0.6 \\
\text { and } 0.9\end{array}$ & NA & 3 & Yes & Yes \\
\hline $\begin{array}{c}\text { Ma et al., } \\
2019\end{array}$ & $\begin{array}{l}\text { DRZ has potential as effective type of } \\
\text { SDI for wine grapes. Other: WP. }\end{array}$ & Field & $\begin{array}{l}\text { Washington } \\
\text { (NW) }\end{array}$ & $\begin{array}{l}\text { Loamy } \\
\text { fine sand }\end{array}$ & $\begin{array}{l}0.3,0.6 \\
\text { or } 0.9 \\
\end{array}$ & 1.8 & 3 & Yes & NA \\
\hline $\begin{array}{l}\text { Saefuddin } \\
\text { et al., } 2019\end{array}$ & $\begin{array}{l}\text { Experimental and Hydrus evaluations of } \\
\text { novel ring-shaped emitter intended for } \\
\text { small-scale tomato and strawberry farms. }\end{array}$ & $\begin{array}{l}\text { Modeling } \\
\text { /Lab }\end{array}$ & NA & $\begin{array}{l}\text { Silt and } \\
\text { sand }\end{array}$ & 0.15 & NA & 1 & No & NA \\
\hline $\begin{array}{l}\text { Sharma et al., } \\
2014\end{array}$ & $\begin{array}{l}\text { Deficit SDI tended to improve melon } \\
\text { quality, although yield was reduced by } \\
24 \% \text { to } 43 \% \text {. Other: Fertigation; WP. }\end{array}$ & Field & $\begin{array}{l}\text { Texas } \\
\text { (SW) }\end{array}$ & Silty clay & 0.15 & 2.0 & 2 & Yes & NA \\
\hline $\begin{array}{l}\text { Sharma et al., } \\
2018 \\
\end{array}$ & $\begin{array}{l}\text { Root growth for melon extended beyond } \\
\text { region wetted by SDI. Other: Fertigation. }\end{array}$ & Field & $\begin{array}{l}\text { Texas } \\
(\mathrm{SW})\end{array}$ & Clay & 0.15 & 2.0 & 2 & Yes & Yes \\
\hline $\begin{array}{l}\text { Slack et al., } \\
2017\end{array}$ & $\begin{array}{l}\text { Using Hydrus, recommended depth } \\
\text { was } 0.3 \mathrm{~m} \text { to avoid surface wetting } \\
\text { with SDI for lettuce. }\end{array}$ & Modeling & NA & $\begin{array}{l}\text { Sandy clay } \\
\text { loam and } \\
\text { loam }\end{array}$ & 0.2 & 1.3 & 1 & No & NA \\
\hline $\begin{array}{l}\text { Zhu-Barker } \\
\text { et al., } 2019\end{array}$ & $\begin{array}{l}\text { SDI generally had less GHG emissions } \\
\text { than alternative irrigation systems } \\
\text { for several horticultural crops. }\end{array}$ & Review & California & NA & NA & NA & NA & No & Yes \\
\hline $\begin{array}{l}\text { Zúñiga-Espinoza } \\
\text { et al., } 2017\end{array}$ & $\begin{array}{l}\text { Potential to use remote sensing to } \\
\text { estimate water stress and manage } \\
\text { DRZ irrigation for wine grapes. }\end{array}$ & Field & $\begin{array}{l}\text { Washington } \\
\text { (NW) }\end{array}$ & $\begin{array}{l}\text { Loamy } \\
\text { fine sand }\end{array}$ & $\begin{array}{l}0.3,0.6 \\
\text { and } 0.9\end{array}$ & 2.4 & 4 & Yes & NA \\
\hline $\begin{array}{c}\text { Zúñiga-Espinoza } \\
\text { et al., } 2018 \\
\end{array}$ & $\begin{array}{l}\text { DRZ irrigation maintained wine grape } \\
\text { canopy vigor at } 60 \% \text { of full irrigation. }\end{array}$ & Field & $\begin{array}{l}\text { Washington } \\
\text { (NW) }\end{array}$ & $\begin{array}{l}\text { Loamy } \\
\text { fine sand }\end{array}$ & $\begin{array}{l}0.3,0.6 \\
\text { and } 0.9\end{array}$ & 2.4 & 4 & No & NA \\
\hline \multicolumn{10}{|c|}{ Studies primarily using SDI as an efficient or convenient irrigation system } \\
\hline $\begin{array}{c}\text { Elsayed-Farag } \\
\text { et al., } 2018\end{array}$ & $\begin{array}{l}\text { White mulch was better than bare or black } \\
\text { mulch for tomato. Other: Fertigation. }\end{array}$ & Field & $\begin{array}{l}\text { Texas } \\
(\mathrm{SW})\end{array}$ & $\begin{array}{l}\text { Fine sandy } \\
\text { loam }\end{array}$ & 0.05 & 2.0 & 1 & Yes & NA \\
\hline $\begin{array}{l}\text { Enciso et al., } \\
2019 \\
\end{array}$ & $\begin{array}{l}\text { Different tomato varieties evaluated } \\
\text { with UAV and field measurements. }\end{array}$ & Field & $\begin{array}{l}\text { Texas } \\
(\mathrm{SW})\end{array}$ & NA & $\begin{array}{c}0.25 \text { to } \\
0.30\end{array}$ & 2.0 & 1 & No & NA \\
\hline $\begin{array}{l}\text { Wright et al., } \\
2018\end{array}$ & $\begin{array}{l}\text { On-surface curing of onion reduced } \\
\text { pathogen concerns. Other: Fertigation. }\end{array}$ & Field & $\begin{array}{l}\text { Oregon } \\
(\mathrm{NW})\end{array}$ & Silt loam & 0.1 & NA & 1 & No & NA \\
\hline
\end{tabular}

netted melons were better able to adjust to moderate water deficits compared to the honeydew melon.

The required SDI replacement fraction of ET (i.e., a range of $25 \%$ to $125 \%$ of ET) was evaluated for guayule production on sandy loam and sandy clay loam soils in Arizona (Hunsaker et al., 2019). The researchers found a linear response to total applied water, and the greatest yield was for SDI replacing $125 \%$ of ET, which was twice the guayule yield reported for the same treatment in a companion SGI study (Hunsaker and Elshikha, 2017).

The application of fumigants with SDI was found to be adequate for grape vines but less so than deep-shanked methyl bromide in a study on a fine sandy loam in California (Cabrera et al., 2012). As methyl bromide is being phased out due to its damaging effects on the ozone layer, the development of other fumigant technologies is of great importance.
The proof-of-concept of DRZ technology (Jacoby and Ma, 2018), which was discussed in the previous section, resulted in additional studies to improve DRZ strategies and effectiveness for wine grapes. The irrigation delivery rate (volume per irrigation event) was found (Ma et al., 2019) to be more important for maintaining grape water status than the DRZ depth (e.g., $0.3,0.6$, or $0.9 \mathrm{~m}$ ), with a moderate delivery rate saving water without greatly reducing yield as compared to the higher delivery rate. Later studies appeared to concentrate more effort on the intermediate $0.6 \mathrm{~m}$ depth (Ma et al., 2020a, 2020b). Another DRZ study in Washington (Chakraborty et al., 2019) found that canopy structures for apple trees and wine grapes were not greatly affected by DRZ depth and were not affected by irrigation delivery rate, although the researchers indicated that winter snowpack may have influenced the results. Efforts to further evaluate and 
optimize DRZ technology through remote sensing were reported by Zúñiga-Espinoza et al. (2016, 2017, 2018). Remotely sensed wine grape vigor was found to be maintained with $60 \%$ of full irrigation using DRZ (Zúñiga-Espinoza et al., 2018).

\section{SDI AS AN EFFICIENT OR CONVENIENT IRRIGATION SYSTEM FOR HORTICULTURAL CROPS}

Three studies were in this subcategory (table 4) and included a study of plastic mulch effectiveness for tomato (Elsayed-Farag et al., 2018), evaluation of tomato varieties using unmanned aerial vehicles (UAVs) (Enciso et al., 2019), and evaluation of pathogen control with on-surface curing of onions when using SDI (Wright et al., 2018).

\section{Forage CROPS}

Twenty-one studies involving forage crops were found in the review process (table 5) spread across three subcategories. There were no reported studies comparing SDI to dryland (i.e., the second of the four subcategories).

\section{SDI IN COMPARISON TO AlTERNATIVE IRRIGATION SYSTEMS FOR FORAGE CROPS}

Only two studies discussed SDI in comparison to alternative irrigation systems for forage crops (table 5). Alfalfa yield was modeled to be $7.9 \mathrm{Mg} \mathrm{ha}^{-1}$ greater with SDI as compared to SGI, and SDI was deemed to be profitable for the long-season growing regions of California but not for the short-season intermountain regions (Montazar et al., 2017). In a survey of commercial alfalfa operations in California, producers claimed $10 \%$ to $30 \%$ yield increases and $20 \%$ to $30 \%$ water savings with SDI compared to SGI (Zaccaria et al., 2017). However, UC-Davis field research found only a $5 \%$ yield increase and that water use increased $2 \%$ to $3 \%$. The survey also found that the most common dripline depth and spacing were 0.3 and $1.0 \mathrm{~m}$, respectively.

\section{STUdies OF SDI RESPONSES AND/OR PERFORMANCE IMPROVEMENTS FOR FORAGE CROPS}

Eleven forage crop studies measured a specific response to SDI or intended to improve SDI performance (table 5). Two studies with very deep SDI $(0.9 \mathrm{~m})$ on loam soils in Wyoming sought to use or disperse coal-mining produced waters for alfalfa and grass production. Water and solute movement in these studies was discussed by Bern et al. (2013a), and the soil geochemistry after six years of application was also reported by Bern et al. (2013a). They concluded that it was viable to deep subsurface apply sodic waters without causing sodicity problems at the soil surface.

Four studies in Alabama on a black vertisol clay examined on-site wastewater dispersal with SDI for sudangrass and wheat. The researchers concluded that a standalone SDI system was not suitable on this vertisol (He et al., 2011) because nutrient loading could be excessive (He et al., 2013a) and because salts would accumulate on the soil surface (He et al., 2013b). A modeling and field study indicated that there was a potential for increased denitrification by regulating $\mathrm{N}$ application with the soil water level (He et al., 2013c).
Hydrus 2-D modeling was used to develop a modeling framework for various design and management practices in relation to different alfalfa root distributions for three soil types (Kandelous et al., 2012). Hydrus modeling was also used by Reyes-Esteves and Slack (2019a, 2019b, 2021) to determine that a minimum dripline depth of $0.5 \mathrm{~m}$ was recommended to avoid alfalfa harvesting problems.

SDI studies with alfalfa in Kansas on a deep silt loam soil recommended an 85\% ET replacement regime (Lamm et al., $2012 \mathrm{~b}$ ), although a replacement regime of $70 \%$ to $85 \%$ ET was sufficient to maintain yield and quality (Harmoney et al., 2013). The wetter regime was recommended because the $70 \%$ ET regime became progressively drier during the growing season, and the soil profile might not be replenished during more extensive drought periods.

\section{SDI AS AN EFFICIENT OR CONVENIENT IRRIGATION SYSTEM FOR FORAGE CROPS}

Eight forage studies were included in this category (table 5). Five studies in Texas examined integrated cotton crop/livestock grazing systems using SDI. In general, the researchers concluded that the crop/livestock system required less irrigation as compared with monoculture cotton (Allen et al., 2012; Zilverberg et al., 2014), less energy (Zilverberg et al., 2012), less chemical inputs (Allen et al., 2012), and had less economic risk (Johnson et al., 2013). Another study suggested that grazing rye may suppress the allelopathic effects of rye on cotton growth and production (Li et al., 2013).

A biomass study in Texas using deficit SDI found greater silage yield for forage sorghum than for pearl millet or corn (Bhattarai et al., 2020). In two energy biomass studies, biomass sorghums out yielded traditional forage sorghums (Chavez et al., 2019) and biomass sorghum chemical quality did not vary with irrigation level (Enciso et al., 2015a).

\section{Turf Grasses}

Fifteen studies involving turf grasses for general landscape were found in the review process (table 6) spread across three subcategories. There were no reported studies comparing SDI to dryland (i.e., the second of the four subcategories). All of the reports in this crop category were generated from studies conducted in New Mexico.

\section{SDI IN COMPARISON TO ALTERNATIVE IRRIGATION SYSTEMS FOR TURF GRASSES}

Twelve studies were included in this subcategory (table 6). Neither SDI nor SprI could use saline irrigation water (3.5 $\left.\mathrm{dS} \mathrm{m}^{-1}\right)$ and maintain acceptable quality for most coolseason turf grasses except for tall fescue in this region (Sevostianova et al., 2011a). However, SDI resulted in earlier green-up than SprI for warm-season grasses and could maintain acceptable quality using the same level of water salinity (Sevostianova et al., 2011a). In further work, Schiavon et al. (2013) noted slower establishment of tall fescue and Kentucky bluegrass with SDI than for SprI and indicated additional that work would be needed to determine if quality could be maintained as soil electrical conductivity (EC) 
Table 5. Identified SDI research studies in the U.S. concerning forage, 2010 through 2020.

\begin{tabular}{|c|c|c|c|c|c|c|c|c|c|}
\hline \multirow[b]{2}{*}{ Study } & \multirow[b]{2}{*}{$\begin{array}{c}\text { Highlights and Other Reported } \\
\text { Factors or Data }\end{array}$} & \multirow[b]{2}{*}{$\begin{array}{l}\text { Study } \\
\text { Type }\end{array}$} & \multirow{2}{*}{$\begin{array}{l}\text { U.S. State } \\
\text { and/or } \\
\text { Region }\end{array}$} & \multirow[b]{2}{*}{$\begin{array}{c}\text { Soil } \\
\text { Type }\end{array}$} & \multicolumn{2}{|c|}{ Driplines $^{[\mathrm{a}]}$} & \multirow{2}{*}{$\begin{array}{l}\text { No. of } \\
\text { Water } \\
\text { Levels }\end{array}$} & \multirow[b]{2}{*}{$\begin{array}{l}\text { Crop } \\
\text { Yield } \\
\end{array}$} & \multirow[b]{2}{*}{$\begin{array}{c}\text { SDI } \\
\text { Benefit }\end{array}$} \\
\hline & & & & & $\begin{array}{l}\text { Depth } \\
(\mathrm{m})\end{array}$ & $\begin{array}{l}\text { Spacing } \\
(\mathrm{m})\end{array}$ & & & \\
\hline \multicolumn{10}{|c|}{ Studies comparing SDI to alternative irrigation systems and also possibly to dryland production or possibly to improve SDI performance } \\
\hline $\begin{array}{l}\text { Montazar } \\
\text { et al., } 2017\end{array}$ & $\begin{array}{l}\text { SDI obtained } 7.9 \mathrm{Mg} \mathrm{ha}^{-1} \text { greater alfalfa } \\
\text { yield than SGI, and economic viability } \\
\text { of SDI alfalfa is discussed. Other: WP. }\end{array}$ & Modeling & $\begin{array}{l}\text { California } \\
\text { (W) }\end{array}$ & $\begin{array}{l}\text { Sandy, } \\
\text { silty loam, } \\
\text { silty clay, } \\
\text { clay loam } \\
\end{array}$ & $\begin{array}{c}0.20 \text { to } \\
0.41\end{array}$ & $\begin{array}{l}1.0 \text { to } \\
1.5\end{array}$ & NA & Yes & Yes \\
\hline $\begin{array}{c}\text { Zaccaria } \\
\text { et al., } 2017\end{array}$ & $\begin{array}{l}\text { Most common commercial SDI depth } \\
\text { and spacing for alfalfa were } 0.3 \text { and } 1.0 \mathrm{~m} \text {, } \\
\text { respectively. Other: SGI; Economics; WP. }\end{array}$ & $\begin{array}{l}\text { Survey } \\
\text { /Field }\end{array}$ & $\begin{array}{l}\text { California } \\
\text { (W) }\end{array}$ & $\begin{array}{l}\text { Silty clay } \\
\text { loam }\end{array}$ & 0.3 & $\begin{array}{c}0.75 \text { and } \\
1.00\end{array}$ & 1 & Yes & Yes \\
\hline \multicolumn{10}{|c|}{ Studies attempting to evaluate a response specifically for SDI or to improve SDI performance } \\
\hline $\begin{array}{l}\text { Bern et al., } \\
2013 \mathrm{a}\end{array}$ & $\begin{array}{l}\text { Deep SDI may be useful in managing } \\
\text { saline waters from coal mining } \\
\text { for alfalfa and grass. }\end{array}$ & Field & $\begin{array}{l}\text { Wyoming } \\
\text { (W) }\end{array}$ & Loam & 0.92 & $\begin{array}{l}1.0 \text { and } \\
1.5\end{array}$ & 1 & NA & Yes \\
\hline $\begin{array}{l}\text { Bern et al., } \\
2013 b\end{array}$ & $\begin{array}{l}\text { SDI applied coal mining sodic waters } \\
\text { subsurface rather than on the } \\
\text { surface for alfalfa and grass. }\end{array}$ & Field & $\begin{array}{l}\text { Wyoming } \\
\text { (W) }\end{array}$ & Loam & 0.92 & $\begin{array}{l}1.0 \text { and } \\
1.5\end{array}$ & 1 & NA & Yes \\
\hline $\begin{array}{l}\text { Harmoney } \\
\text { et al., } 2013\end{array}$ & $\begin{array}{l}\text { SDI replacing } 70 \% \text { to } 85 \% \text { ET can } \\
\text { maintain alfalfa yield and quality. }\end{array}$ & Field & $\begin{array}{c}\text { Kansas } \\
\text { MW) }\end{array}$ & Silt loam & 0.5 & 1.5 & 3 & Yes & NA \\
\hline $\begin{array}{c}\text { He et al., } \\
2011\end{array}$ & $\begin{array}{l}\text { Standalone SDI dispersal was not suitable } \\
\text { on a vertisol for sudangrass and wheat. }\end{array}$ & Field & $\begin{array}{l}\text { Alabama } \\
(\mathrm{SE})\end{array}$ & Clay & $\begin{array}{l}0.20 \text { to } \\
0.25\end{array}$ & 0.61 & NA & No & NA \\
\hline $\begin{array}{c}\text { He et al., } \\
2013 \mathrm{a}\end{array}$ & $\begin{array}{c}\text { Nutrient loading could be excessive } \\
\text { with SDI as implemented for } \\
\text { sudangrass and wheat. }\end{array}$ & Field & $\begin{array}{l}\text { Alabama } \\
\text { (SE) }\end{array}$ & Clay & $\begin{array}{l}0.20 \text { to } \\
0.25\end{array}$ & 0.61 & NA & Yes & NA \\
\hline $\begin{array}{l}\text { He et al., } \\
2013 b\end{array}$ & $\begin{array}{l}\text { Salts tended to accumulate at soil surface } \\
\text { with SDI for sudangrass and wheat. }\end{array}$ & Field & $\begin{array}{l}\text { Alabama } \\
\text { (SE) }\end{array}$ & Clay & $\begin{array}{l}0.20 \text { to } \\
0.25\end{array}$ & 0.61 & NA & No & NA \\
\hline $\begin{array}{l}\text { He et al., } \\
2013 \mathrm{c}\end{array}$ & $\begin{array}{l}\text { Potential for increased denitrification by } \\
\text { regulating } \mathrm{N} \text { application with soil water } \\
\text { level for sorghum sudangrass and wheat. }\end{array}$ & $\begin{array}{l}\text { Modeling } \\
\text { /Field }\end{array}$ & $\begin{array}{l}\text { Alabama } \\
\text { (SE) }\end{array}$ & Clay & $\begin{array}{l}0.20 \text { to } \\
0.25\end{array}$ & 0.61 & NA & No & NA \\
\hline $\begin{array}{l}\text { Kandelous } \\
\text { et al., } 2012\end{array}$ & $\begin{array}{l}\text { Using Hydrus 2D, a design and } \\
\text { management framework for alfalfa root } \\
\text { distributions and soils is presented. }\end{array}$ & Modeling & $\begin{array}{l}\text { California } \\
\text { (W) }\end{array}$ & $\begin{array}{l}\text { Loam, } \\
\text { sandy loam, } \\
\text { clay loam }\end{array}$ & 0.6 & NA & NA & NA & NA \\
\hline $\begin{array}{l}\text { Lamm et al., } \\
2012 b\end{array}$ & $\begin{array}{l}85 \% \text { ET replacement for alfalfa in this } \\
\text { region was recommended. Other: WP. }\end{array}$ & Field & $\begin{array}{c}\text { Kansas } \\
\text { (MW) }\end{array}$ & Silt loam & 0.5 & 1.5 & 3 & Yes & NA \\
\hline $\begin{array}{l}\text { Reyes-Esteves } \\
\text { and Slack, } \\
\text { 2019a, 2021 }\end{array}$ & $\begin{array}{l}\text { Using Hydrus, dripline depth of } 0.5 \mathrm{~m} \\
\text { is recommended to avoid harvesting } \\
\text { problems. The } 2021 \text { article corrects } \\
\text { and discusses the } 2019 \text { article. }\end{array}$ & $\begin{array}{l}\text { Modeling } \\
\text { /Field }\end{array}$ & $\begin{array}{l}\text { California } \\
\text { (W) }\end{array}$ & $\begin{array}{l}\text { Sandy clay } \\
\text { loam clay } \\
\text { loam }\end{array}$ & $\begin{array}{l}0.3 \text { and } \\
0.5\end{array}$ & 1.0 & 2 & No & NA \\
\hline $\begin{array}{c}\text { Reyes-Esteves } \\
\text { and Slack, } \\
2019 \mathrm{~b}\end{array}$ & $\begin{array}{l}\text { Using Hydrus, minimum SDI placement } \\
\text { depth for three soils is reported for alfalfa. }\end{array}$ & $\begin{array}{l}\text { Modeling } \\
\text { /Field }\end{array}$ & $\begin{array}{l}\text { California } \\
\text { (W) }\end{array}$ & $\begin{array}{l}\text { Sandy clay } \\
\text { loam, clay } \\
\text { loam, loam }\end{array}$ & 0.5 & 1.0 & 1 & No & NA \\
\hline \multicolumn{10}{|c|}{ Studies primarily using SDI as an efficient or convenient irrigation system } \\
\hline $\begin{array}{l}\text { Allen et al., } \\
2012\end{array}$ & $\begin{array}{l}\text { Crop/livestock system used less } \\
\text { irrigation and chemical inputs than } \\
\text { monoculture cotton. Other: Economics. }\end{array}$ & Field & $\begin{array}{l}\text { Texas } \\
(\mathrm{SW})\end{array}$ & Clay loam & 0.36 & 1.0 & 1 & Yes & NA \\
\hline $\begin{array}{l}\text { Bhattarai } \\
\text { et al., } 2020\end{array}$ & $\begin{array}{l}\text { Greater silage yields under deficit } \\
\text { irrigation with forage sorghum than } \\
\text { for pearl millet and corn. Other: WP. }\end{array}$ & Field & $\begin{array}{l}\text { Texas } \\
(\mathrm{SW})\end{array}$ & Clay loam & NA & NA & 3 & Yes & NA \\
\hline $\begin{array}{l}\text { Chavez et al., } \\
2019 \\
\end{array}$ & $\begin{array}{l}\text { Biomass sorghums yielded better than } \\
\text { forage sorghums. Other: WP. }\end{array}$ & Field & $\begin{array}{l}\text { Texas } \\
(\mathrm{SW})\end{array}$ & Sandy loam & NA & 1.0 & 1 & Yes & $\mathrm{NA}$ \\
\hline $\begin{array}{c}\text { Enciso et al., } \\
2015 \mathrm{a}\end{array}$ & $\begin{array}{c}\text { Biomass sorghum chemical quality } \\
\text { did not differ with irrigation level. } \\
\text { Other: Economics; WP. }\end{array}$ & Field & $\begin{array}{l}\text { Texas } \\
(\mathrm{SW})\end{array}$ & $\begin{array}{l}\text { Sandy clay } \\
\text { loam }\end{array}$ & NA & NA & 4 & Yes & Yes \\
\hline $\begin{array}{c}\text { Johnson } \\
\text { et al., } 2013\end{array}$ & $\begin{array}{l}\text { Less economic risk with crop/livestock } \\
\text { system than for monoculture cotton. }\end{array}$ & Field & $\begin{array}{l}\text { Texas } \\
(\mathrm{SW})\end{array}$ & NA & 0.36 & 1 & 1 & Yes & NA \\
\hline $\begin{array}{c}\text { Li et al., } \\
2013\end{array}$ & $\begin{array}{l}\text { Cattle grazing and allelopathy of rye } \\
\text { are discussed. Other: Cotton. }\end{array}$ & Field & $\begin{array}{l}\text { Texas } \\
(\mathrm{SW})\end{array}$ & Clay loam & NA & NA & 1 & Yes & NA \\
\hline $\begin{array}{l}\text { Zilverberg } \\
\text { et al., } 2012\end{array}$ & $\begin{array}{l}\text { Monoculture cotton used more energy } \\
\text { than integrated crop/livestock system. }\end{array}$ & Field & $\begin{array}{l}\text { Texas } \\
(\mathrm{SW})\end{array}$ & Clay loam & 0.36 & 1.0 & 1 & No & NA \\
\hline $\begin{array}{l}\text { Zilverberg } \\
\text { et al., } 2014\end{array}$ & $\begin{array}{l}\text { Monoculture cotton used more irrigation } \\
\text { than integrated crop/livestock. }\end{array}$ & Field & Texas (SW) & Clay loam & 0.36 & 1.0 & 2 & Yes & NA \\
\hline
\end{tabular}

levels increased. Similarly, Ganjegunte et al. (2013), using electromagnetic inductance, measured greater soil EC for SDI than for SprI turf grasses.

Slower establishment of Bermuda grass with SDI compared to SprI could be partially compensated for by earlier propagation (Serena et al., 2014). Seven studies published between 2012 and 2020 evaluated Bermuda grass and seashore paspalum under SDI and SprI (table 6). Overall, these studies found that SDI generally had slower turf grass establishment than SprI and could benefit from earlier seeding 
Table 6. Identified SDI research studies in the U.S. concerning turf grasses, 2010 through 2020.

\begin{tabular}{|c|c|c|c|c|c|c|c|c|c|}
\hline \multirow[b]{2}{*}{ Study } & \multirow[b]{2}{*}{$\begin{array}{l}\text { Highlights and Other Reported } \\
\text { Factors or Data } \\
\end{array}$} & \multirow[b]{2}{*}{$\begin{array}{l}\text { Study } \\
\text { Type }\end{array}$} & \multirow{2}{*}{$\begin{array}{l}\text { U.S. State } \\
\text { and/or } \\
\text { Region } \\
\end{array}$} & \multirow[b]{2}{*}{$\begin{array}{l}\text { Soil } \\
\text { Type }\end{array}$} & \multicolumn{2}{|c|}{ Driplines $^{[\mathrm{a}]}$} & \multirow{2}{*}{$\begin{array}{l}\text { No. of } \\
\text { Water } \\
\text { Levels }\end{array}$} & \multirow[b]{2}{*}{$\begin{array}{l}\text { Crop } \\
\text { Yield }\end{array}$} & \multirow[b]{2}{*}{$\begin{array}{c}\text { SDI } \\
\text { Benefit }\end{array}$} \\
\hline & & & & & $\begin{array}{l}\text { Depth } \\
(\mathrm{m})\end{array}$ & $\begin{array}{l}\text { Spacing } \\
(\mathrm{m})\end{array}$ & & & \\
\hline \multicolumn{10}{|c|}{ Studies comparing SDI to alternative irrigation systems and also possibly to dryland production or possibly to improve SDI performance } \\
\hline $\begin{array}{l}\text { Ganjegunte } \\
\text { et al., } 2013 \\
\end{array}$ & $\begin{array}{l}\text { Soil salinity and sodicity greater with } \\
\text { SDI than with SprI for turf. }\end{array}$ & Field & $\begin{array}{l}\text { New Mexico } \\
(\mathrm{SW})\end{array}$ & Fine sand & 0.1 & 0.6 & 1 & NA & No \\
\hline $\begin{array}{l}\text { Schiavon et al., } \\
2012\end{array}$ & $\begin{array}{l}\text { Bermuda grass and seashore paspalum } \\
\text { could be established with SDI but earlier } \\
\text { seeding would be required than for SprI. }\end{array}$ & Field & $\begin{array}{l}\text { New Mexico } \\
\text { (SW) }\end{array}$ & $\begin{array}{l}\text { Sandy } \\
\text { loam }\end{array}$ & 0.1 & 0.3 & 1 & NA & $\begin{array}{l}\text { Mixed } \\
\text { results }\end{array}$ \\
\hline $\begin{array}{l}\text { Schiavon et al., } \\
2013\end{array}$ & $\begin{array}{l}\text { SDI had slower establishment than for } \\
\text { SprI for fescue and Kentucky bluegrass. }\end{array}$ & Field & $\begin{array}{l}\text { New Mexico } \\
(\mathrm{SW})\end{array}$ & $\begin{array}{l}\text { Sandy } \\
\text { loam }\end{array}$ & 0.1 & 0.33 & 1 & NA & No \\
\hline $\begin{array}{l}\text { Schiavon et al., } \\
2014 \mathrm{a}\end{array}$ & $\begin{array}{l}\text { After three years, SDI had greater quality } \\
\text { and NDVI for Bermuda grass and } \\
\text { seashore paspalum than for SprI. }\end{array}$ & Field & $\begin{array}{l}\text { New Mexico } \\
\text { (SW) }\end{array}$ & $\begin{array}{l}\text { Sandy } \\
\text { loam }\end{array}$ & 0.1 & 0.33 & 1 & NA & Yes \\
\hline $\begin{array}{l}\text { Schiavon et al., } \\
2014 \mathrm{~b}\end{array}$ & $\begin{array}{l}\text { SDI may be more effective than SprI for } \\
\text { maintaining Bermuda grass and seashore } \\
\text { paspalum quality under deficit irrigation. }\end{array}$ & Field & $\begin{array}{l}\text { New Mexico } \\
\text { (SW) }\end{array}$ & $\begin{array}{l}\text { Sandy } \\
\text { loam }\end{array}$ & 0.1 & 0.33 & 1 & NA & Yes \\
\hline $\begin{array}{l}\text { Schiavon et al., } \\
2015\end{array}$ & $\begin{array}{l}\text { Slower SDI Bermuda grass and seashore } \\
\text { paspalum establishment in New Mexico } \\
\text { than for California. Other: SprI. }\end{array}$ & Field & $\begin{array}{c}\text { New Mexico } \\
\text { (SW) and } \\
\text { California } \\
(W)\end{array}$ & $\begin{array}{c}\text { Sandy } \\
\text { loam and } \\
\text { fine sandy } \\
\text { clay loam } \\
\end{array}$ & 0.1 & 0.3 & 1 & NA & $\begin{array}{l}\text { Mixed } \\
\text { results }\end{array}$ \\
\hline $\begin{array}{l}\text { Serena et al., } \\
2014\end{array}$ & $\begin{array}{l}\text { Bermuda grass was slower to reach full } \\
\text { coverage and had lesser root density } \\
\text { with SDI than with SprI. }\end{array}$ & Field & $\begin{array}{l}\text { New Mexico } \\
\text { (SW) }\end{array}$ & $\begin{array}{l}\text { Sandy } \\
\text { loam }\end{array}$ & 0.1 & 0.3 & 1 & NA & No \\
\hline $\begin{array}{l}\text { Serena et al., } \\
2017 \mathrm{a}\end{array}$ & $\begin{array}{l}\text { Bermuda grass and seashore paspalum } \\
\text { were slower to exhibit green-up } \\
\text { with SDI than with SprI. }\end{array}$ & Field & $\begin{array}{l}\text { New Mexico } \\
\text { (SW) }\end{array}$ & $\begin{array}{l}\text { Loamy } \\
\text { sand }\end{array}$ & 0.1 & 0.3 & 1 & NA & No \\
\hline $\begin{array}{l}\text { Serena et al., } \\
2017 b\end{array}$ & $\begin{array}{l}\text { Irrigation system (SDI and SprI) had } \\
\text { little effect on carbohydrate content for } \\
\text { Bermuda grass and seashore paspalum. }\end{array}$ & Field & $\begin{array}{l}\text { New Mexico } \\
\text { (SW) }\end{array}$ & $\begin{array}{l}\text { Loamy } \\
\text { sand }\end{array}$ & 0.1 & 0.3 & 1 & NA & $\begin{array}{l}\text { Mixed } \\
\text { results }\end{array}$ \\
\hline $\begin{array}{l}\text { Serena et al., } \\
2020\end{array}$ & $\begin{array}{l}\text { SDI had improved drought avoidance, } \\
\text { green cover, and turf quality compared } \\
\text { to SprI for Bermuda grass and } \\
\text { seashore paspalum. }\end{array}$ & Field & $\begin{array}{l}\text { New Mexico } \\
\text { (SW) }\end{array}$ & $\begin{array}{l}\text { Loamy } \\
\text { sand }\end{array}$ & 0.1 & 0.3 & 1 & NA & Yes \\
\hline $\begin{array}{l}\text { Sevostianova } \\
\text { et al., 2011b }\end{array}$ & $\begin{array}{l}\text { Earlier green-up with SDI compared to } \\
\text { SprI for nine warm season turf grasses. }\end{array}$ & Field & $\begin{array}{c}\text { New Mexico } \\
(\mathrm{SW})\end{array}$ & $\begin{array}{l}\text { Sandy } \\
\text { loam }\end{array}$ & 0.075 & 0.3 & 1 & NA & Yes \\
\hline $\begin{array}{c}\text { Sevostianova } \\
\text { et al., 2011a }\end{array}$ & $\begin{array}{l}\text { Soil EC was greater with SDI than with } \\
\text { SprI for seven cool-season turf grasses. }\end{array}$ & Field & $\begin{array}{l}\text { New Mexico } \\
(\mathrm{SW})\end{array}$ & $\begin{array}{c}\text { Sandy } \\
\text { loam }\end{array}$ & 0.075 & 0.3 & 1 & NA & No \\
\hline \multicolumn{10}{|c|}{ Studies attempting to evaluate a response specifically for SDI or to improve SDI performance } \\
\hline $\begin{array}{l}\text { Schiavon et al., } \\
2011\end{array}$ & $\begin{array}{l}\text { Warm-season grasses were evaluated } \\
\text { with SDI for quality. }\end{array}$ & Field & $\begin{array}{l}\text { New Mexico } \\
\text { (SW) }\end{array}$ & $\begin{array}{l}\text { Sandy } \\
\text { clay loam }\end{array}$ & 0.1 & 0.3 & 1 & NA & NA \\
\hline $\begin{array}{l}\text { Sevostianova and } \\
\text { Leinauer, } 2014 \\
\end{array}$ & $\begin{array}{l}\text { Potential to use effluent and fertigation } \\
\text { for SDI turf grasses. Other: Fertigation. }\end{array}$ & Review & NA & NA & NA & NA & NA & NA & Yes \\
\hline \multicolumn{10}{|c|}{ Studies primarily using SDI as an efficient or convenient irrigation system } \\
\hline $\begin{array}{l}\text { Leinauer et al., } \\
2010\end{array}$ & $\begin{array}{l}\text { Seed coatings may improve turf grass } \\
\text { germination when using SDI. }\end{array}$ & Field & $\begin{array}{l}\text { New Mexico } \\
(\mathrm{SW})\end{array}$ & Sandy & 0.1 & 0.3 & 2 & NA & NA \\
\hline
\end{tabular}

(Schiavon et al., 2012, 2015; Serena et al., 2017a) and that irrigation system had little effect on the carbohydrate content of the turf grasses (Serena et al., 2017b), but with successful establishment, SDI would have better long-term turf quality and drought avoidance (Schiavon et al., 2014a, 2014b; Serena et al., 2020).

\section{STUdies of SDI Responses ANd/OR Performance IMPROVEMENTS FOR TURF GRASSES}

Two studies were included in this subcategory (table 6): an early study to determine the potential of SDI for turf grasses (Schiavon et al., 2011), and a literature review concerning the potential for using treated effluent and $\mathrm{N}$ fertigation for turf grasses with SDI (Sevostianova and Leinauer, 2014). The review concluded that combined technologies (i.e., treated effluent and $\mathrm{N}$ fertigation) with SDI could become an important way to sustain green spaces in urban settings.

\section{SDI AS AN EFFICIENT OR CONVENIENT IRRIGATION SYSTEM FOR TURF GRASSES}

A study to evaluate seed coatings to enhance germination was conducted with SDI on a sandy soil (Leinauer et al., 2010), finding that seed coatings were beneficial but that further research was needed to determine if full turf coverage could be achieved.

\section{StUdies With No SPeCIFIC CROP}

Seventeen studies that mentioned no crop or that were not crop-specific were found in the review process (table 7) spread across two subcategories.

\section{SDI IN COMPARISON TO ALTERNATIVE IRRIGATION SYSTEMS WITHOUT A SPECIFIC CROP}

Four summary studies discussed the progress and prospects for SDI within the U.S. (table 7). A survey of 
Table 7. Identified SDI research studies in the U.S. not listing a specific crop, 2010 through 2020.

\begin{tabular}{|c|c|c|c|c|c|c|c|c|c|}
\hline \multirow[b]{2}{*}{ Study } & \multirow[b]{2}{*}{$\begin{array}{c}\text { Highlights and Other Reported } \\
\text { Factors or Data }\end{array}$} & \multirow[b]{2}{*}{$\begin{array}{l}\text { Study } \\
\text { Type }\end{array}$} & \multirow{2}{*}{$\begin{array}{l}\text { U.S. State } \\
\text { and/or } \\
\text { Region }\end{array}$} & \multirow[b]{2}{*}{$\begin{array}{c}\text { Soil } \\
\text { Type }\end{array}$} & \multicolumn{2}{|c|}{ Driplines $^{[\mathrm{a}]}$} & \multirow{2}{*}{$\begin{array}{l}\text { No. of } \\
\text { Water } \\
\text { Levels }\end{array}$} & \multirow[b]{2}{*}{$\begin{array}{l}\text { Crop } \\
\text { Yield }\end{array}$} & \multirow[b]{2}{*}{$\begin{array}{c}\text { SDI } \\
\text { Benefit }\end{array}$} \\
\hline & & & & & $\begin{array}{l}\text { Depth } \\
(\mathrm{m})\end{array}$ & $\begin{array}{l}\text { Spacing } \\
(\mathrm{m})\end{array}$ & & & \\
\hline \multicolumn{10}{|c|}{ Studies comparing SDI to alternative irrigation systems and also possibly to dryland production or possibly to improve SDI performance } \\
\hline $\begin{array}{l}\text { Ayars et al., } \\
2015\end{array}$ & $\begin{array}{c}\text { SDI is a valuable tool to increase WP. } \\
\text { Other: Various crops; Fertigation; } \\
\text { Economics. }\end{array}$ & Summary & $\begin{array}{l}\text { California } \\
\text { (W) }\end{array}$ & NA & Various & Various & NA & Yes & Yes \\
\hline $\begin{array}{l}\text { Lamm et al., } \\
2012 \mathrm{a}\end{array}$ & $\begin{array}{l}\text { Status of SDI in } 2010 \text { reported. SDI was } \\
\text { growing in the U.S. and was subject of } \\
\text { considerable research and extension efforts. }\end{array}$ & $\begin{array}{l}\text { Review } \\
\text { /Summary }\end{array}$ & $\begin{array}{l}\text { SE, Great } \\
\text { Plains, } \\
\text { and West }\end{array}$ & NA & NA & NA & NA & NA & Yes \\
\hline $\begin{array}{l}\text { Evett et al., } \\
2020 \mathrm{~b}\end{array}$ & $\begin{array}{l}\text { Texas, Kansas, and Nebraska had } 25 \% \\
\text { of SDI area in the U.S. }\end{array}$ & $\begin{array}{l}\text { Review } \\
\text { /Summary }\end{array}$ & $\begin{array}{l}\text { Great } \\
\text { Plains }\end{array}$ & NA & NA & NA & NA & No & NA \\
\hline $\begin{array}{l}\text { Kandelous and } \\
\text { Šmůnek, 2010a }\end{array}$ & $\begin{array}{l}\text { Wetting zone dimensions were compared } \\
\text { with different models for SDI and DI. }\end{array}$ & $\begin{array}{l}\text { Modeling } \\
\text { /Lab }\end{array}$ & NA & Clay loam & $\begin{array}{l}0.15 \\
\text { and } \\
0.30\end{array}$ & NA & NA & NA & NA \\
\hline $\begin{array}{l}\text { Tindula et al., } \\
2013\end{array}$ & $\begin{array}{l}\text { Processing tomato had the greatest SDI } \\
\text { land area in California in } 2010 \text { at } 9462 \text { ha. }\end{array}$ & $\begin{array}{l}\text { Survey } \\
\text { /Summary }\end{array}$ & $\begin{array}{l}\text { California } \\
\text { (W) }\end{array}$ & NA & NA & NA & NA & NA & NA \\
\hline \multicolumn{10}{|c|}{ Studies attempting to evaluate a response specifically for SDI or to improve SDI performance } \\
\hline $\begin{array}{l}\text { Beggs et al., } \\
2011\end{array}$ & $\begin{array}{l}\text { Nitrogen removal through denitrification } \\
\text { with SDI dispersal system was evaluated. }\end{array}$ & $\begin{array}{l}\text { Modeling } \\
\text { /Lab }\end{array}$ & NA & $\begin{array}{l}\text { Sandy loam, } \\
\text { loamy sand, } \\
\text { and silt loam }\end{array}$ & 0.15 & 0.4 & NA & No & NA \\
\hline $\begin{array}{l}\text { Enciso et al., } \\
2011\end{array}$ & $\begin{array}{l}\text { Longevity of SDI systems was discussed } \\
\text { and poor maintenance was attributed } \\
\text { to cause of reduced uniformity. }\end{array}$ & Field & $\begin{array}{l}\text { Texas } \\
(\mathrm{SW})\end{array}$ & NA & NA & NA & NA & NA & NA \\
\hline $\begin{array}{c}\text { Engle et al., } \\
2011 \\
\end{array}$ & $\begin{array}{l}\text { Water and salt dynamics with deep } \\
\text { SDI dispersal were presented. }\end{array}$ & Field & $\begin{array}{l}\text { Wyoming } \\
\text { (W) }\end{array}$ & $\begin{array}{l}\text { Silt and } \\
\text { fine sand }\end{array}$ & 0.9 & 1.4 & 1 & No & $\begin{array}{l}\text { Mixed } \\
\text { results }\end{array}$ \\
\hline $\begin{array}{c}\text { Evett et al., } \\
2018 \\
\end{array}$ & $\begin{array}{l}\text { Lysimeter estimates of ET for SDI were } \\
\text { improved through additional equipment. }\end{array}$ & Field & $\begin{array}{l}\text { Texas } \\
(\mathrm{SW})\end{array}$ & NA & $\begin{array}{c}0.30 \text { to } \\
0.36\end{array}$ & 1.5 & NA & No & NA \\
\hline $\begin{array}{l}\text { Harbuck et al., } \\
2011 \\
\end{array}$ & $\begin{array}{l}\text { Procedures and equipment for in-field SDI } \\
\text { uniformity measurements were discussed. }\end{array}$ & Lab /Field & $\begin{array}{c}\text { Alabama } \\
(\mathrm{SE})\end{array}$ & NA & NA & NA & NA & No & NA \\
\hline $\begin{array}{l}\text { Kandelous and } \\
\text { Šimůnek, 2010b }\end{array}$ & $\begin{array}{l}\text { Simulated soil water values from Hydrus } \\
\text { 2D compared well with observed values. }\end{array}$ & $\begin{array}{l}\text { Modeling } \\
\text { /Lab }\end{array}$ & NA & Clay loam & $\begin{array}{l}0.05,0.15 \\
0.25, \text { and } \\
0.30\end{array}$ & NA & NA & NA & NA \\
\hline $\begin{array}{l}\text { Kandelous } \\
\text { et al., } 2011\end{array}$ & $\begin{array}{l}\text { Modeling SDI wetting patterns when } \\
\text { water from two emitters overlap may } \\
\text { require three-dimensional modeling. }\end{array}$ & $\begin{array}{l}\text { Modeling } \\
\text { /Lab }\end{array}$ & NA & Clay loam & $\begin{array}{l}0.20,0.25 \\
\text { and } 0.30\end{array}$ & NA & NA & NA & NA \\
\hline $\begin{array}{l}\text { Lamm and } \\
\text { Puig-Bargués, } \\
2017 \\
\end{array}$ & $\begin{array}{l}\text { Simple, self-regulating equations were } \\
\text { presented to size SDI flushlines. }\end{array}$ & Modeling & NA & NA & NA & NA & NA & No & NA \\
\hline $\begin{array}{l}\text { Puig-Bargués } \\
\text { et al., } 2010\end{array}$ & $\begin{array}{l}\text { Increasing flushing velocity, and as } \\
\text { a result flushing volume, increased } \\
\text { removal of solids from driplines. }\end{array}$ & Field/Lab & $\begin{array}{c}\text { Kansas } \\
\text { (MW) }\end{array}$ & Silt loam & 0.075 & NA & NA & No & No \\
\hline $\begin{array}{l}\text { Puig-Bargués } \\
\text { and Lamm, } \\
2013 \\
\end{array}$ & $\begin{array}{l}\text { ASABE Standard EP-405 recommended } \\
\text { minimum flushing velocity of } 0.3 \mathrm{~m} \mathrm{~s}^{-1} \text { still } \\
\text { appears adequate under most conditions. }\end{array}$ & $\mathrm{Lab}$ & $\begin{array}{c}\text { Kansas } \\
\text { (MW) }\end{array}$ & NA & NA & NA & NA & NA & NA \\
\hline $\begin{array}{l}\text { Siegrist et al., } \\
2014 \\
\end{array}$ & $\begin{array}{l}\text { Effective elimination of pathogens } \\
\text { with SDI was discussed. }\end{array}$ & Field & $\begin{array}{l}\text { Colorado } \\
\text { (W) }\end{array}$ & $\begin{array}{l}\text { Sandy } \\
\text { loam }\end{array}$ & $\begin{array}{c}0.2 \text { to } \\
0.3 \\
\end{array}$ & 0.6 & 2 & No & Yes \\
\hline $\begin{array}{l}\text { Skaggs et al., } \\
2010\end{array}$ & $\begin{array}{l}\text { Pulsing had little impact on horizontal } \\
\text { soil water redistribution from SDI. }\end{array}$ & $\begin{array}{l}\text { Modeling } \\
\text { /Field }\end{array}$ & $\begin{array}{l}\text { California } \\
\text { (W) }\end{array}$ & $\begin{array}{l}\text { Sandy } \\
\text { loam }\end{array}$ & 0.06 & NA & 1 & No & NA \\
\hline
\end{tabular}

irrigation methods in California indicated that processing tomato had the greatest land area for SDI at 9462 ha in 2010, as compared to just 30 ha in 2001 (Tindula et al., 2013). In another summary from California, Ayars et al. (2015) concluded that SDI would be a valuable tool for managing irrigation water in California, in some cases increasing crop yield and quality, and in even more cases increasing WP. The status of SDI at the beginning of the last decade within the entire U.S. was summarized by Lamm et al. (2012a), who also reported the opportunities and challenges that exist for SDI adoption. The past, present, and future of irrigation in the Great Plains were discussed by Evett et al. (2020b), who noted the growing interest and use of SDI and other advanced irrigation technologies and their importance in the future.
Various empirical models, the numerical Hydrus 2D model, and the analytical Wet-Up model were used to simulate wetting patterns for both SDI and DI (Kandelous and Šimůnek, 2010b). The researchers reported varied success, with the empirical and numerical models performing better than the analytical model.

\section{STUdies Of SDI Responses ANd/OR PerformanCe IMPROVEMENTS WITHOUT A SPECIFIC CROP}

Twelve studies were included in this subcategory in table 7. A field study in Wyoming examined water and salt dynamics with deep SDI for dispersal of coal-mining produced waters (Engle et al., 2011). Although the researchers indicated the favorable potential of SDI technology, they concluded that further study was justified to understand 
longer-term environmental concerns. Additional discussion of this technology was presented in the Forage Crop section and table 5 of this article entailing the work of Bern et al. (2013a, 2013b).

The fate of $\mathrm{N}$ from small on-site SDI dispersal systems for wastewater was studied with Hydrus 2D modeling and in the laboratory by Beggs et al. (2011). They found that the slow transport with SDI enhanced total $\mathrm{N}$ losses and increased plant $\mathrm{N}$ uptake. In a field study on a sandy loam soil in Colorado with an SDI dispersal system applying effluent, heterotrophic bacteria levels increased in the subsoil, but the SDI system was effective at eliminating Escherichia coli and other coliforms (Siegrist et al., 2014).

In another Hydrus 2D modeling study, simulated volumetric soil water contents within a clay soil profile using SDI corresponded well with measured values (Kandelous and Šimůnek, 2010b). A Hydrus 2D study that examined when the wetting patterns from two adjacent SDI emitters started to overlap concluded that a fully three-dimensional model may be required to adequately describe this process (Kandelous et al., 2011).

The longevity of commercial SDI systems in Texas was discussed by Enciso et al. (2011), and poor maintenance was attributed as the cause of reduced uniformity for many older systems. Additional studies on SDI longevity were mentioned earlier in this article in the Grain and Oilseed Crops section and table 2, specifically Sorensen and Lamb (2015) and Lamm and Rogers (2017). Procedures and equipment to evaluate SDI uniformity in the field were reported by Harbuck et al. (2011).

Flushing of SDI driplines is an important aspect of system maintenance and therefore system longevity. Increasing the flushing velocity to 0.45 or $0.61 \mathrm{~m} \mathrm{~s}^{-1}$ resulted in increased dripline solids removal (Puig-Bargués et al., 2010). However, increasing the flushing velocity over the ASABE-recommended $0.3 \mathrm{~m} \mathrm{~s}^{-1}$ increases SDI system costs considerably, and Puig-Bargués and Lamm (2013) suggested that increasing the frequency and duration of flushing might be a preferable option. Simple equations to size SDI flushlines were presented by Lamm and Puig-Bargués (2017). The equations tend to be self-regulating (i.e., accurate even with a minimal number of parameters because of the scale of typical components and system designs).

SDI, with its inherent nature of applying water below the soil surface, has different dynamics than alternative irrigation systems in the partitioning of ET. Efforts to partition ET when using SDI will likely be improved by the use of better lysimetric estimates that were reported through equipment modifications (Evett et al., 2018).

Pulsing of SDI, in which applications of water are frequently paused and restarted, has been advocated as a means of improving soil water redistribution that might enhance crop germination and establishment. Pulsing of SDI was studied on a sandy loam in California with Hydrus 2D and field data (Skaggs et al., 2010). The researchers found that soil wetting was impacted by soil texture and antecedent soil water content, but was not appreciably impacted by pulsing or the emitter discharge rate.

\section{THE FUTURE OF SDI IN THE U.S.}

At the beginning of the decade (2010), the challenges and perceived opportunities for SDI were discussed by Lamm et al. (2012a), and readers are referred to those studies for additional discussion. Some of the challenges for the adoption and successful use of SDI have lessened in the last decade, and some have not. This article focuses on the primary persistent challenges that remain and on some challenges not listed by Lamm et al. (2012a). Some challenges and opportunities overlap, and successfully addressing a challenge may open an opportunity.

\section{CHALlENGES AND OPPORTUNITIES FOR SDI DESIGN AND INSTALLATION}

In the Great Plains and the western U.S., there has been a considerable reduction in the challenges in this topic area through development of an improved network and a larger number of designers, dealers, and installers with increased support from microirrigation component manufacturers. This is less the case in the southeastern U.S., resulting in less adoption, less producer awareness, and poorer designs (e.g., proper matching of components) and installations. Some producers may install their own systems, but many are uncomfortable doing so. Fields in the southeastern U.S. are often relatively small and irregularly shaped, necessitating more individual designs, but conversely these small SDI fields can be more cost-competitive with CP systems. The coarse-textured soils of the Southeastern Coastal Plain may benefit from shallow SDI installations, but these shallow systems also have challenges related to tillage, cropping, and pest management.

Industry and technical service providers can help address this problem. Some manufacturers are providing better support to designers and installers by developing more standard designs, which can decrease SDI system costs. This is welcome, provided that the long-term system needs of the producer are well identified and that the system operation will be economical in the long run. The goals of an SDI system can have a large effect on the system design and installation, as well as its long-term operation and maintenance. For example, SDI systems applying effluent from animal or human sources may require more complex designs, but at same time may have an increased opportunity for profitability through economical dispersal of effluent. Use of SDI for turf on golf courses, athletic fields, parks, and other urban green spaces is likely to increase in the future, particularly for applying treated effluents (i.e., further reducing human exposure). Freshwater sources can then be conserved for more important uses.

Nationwide, the selection of dripline spacing and depth remains a design and installation challenge when crops with different row spacings and other cultural practices are frequently rotated. Additionally, some fields may be fallowed for weed or pathogen control or are not secured for long-term lease and therefore may not fully use an SDI system. Producers should carefully plan their SDI systems, recognizing that additional flexibility may be desirable as experience is gained. Further research is warranted in examining flat versus bed planting for a variety of crops grown with SDI and 
the interaction with dripline depth and spacing, emitter spacing, and discharge rate. This research could be especially valuable in addressing the germination and crop establishment problems that can occur with SDI. The use of SDI for forage production and turf is anticipated to increase in the future and may require additional innovations in design and installation (e.g., optimum depth and dripline spacing) and in maintenance (e.g., prevention of rodent and mechanical damage to driplines).

Designing and implementing flexible SDI systems can be challenging, as producers may not have a good understanding of their long-term cropping plans and potential for greater cropping intensification. Agrochemical injection systems and/or automated monitoring and control systems add complexity and increase initial costs but can be profitable in the long term through reduction in management and maintenance costs and through increased crop yield and/or quality.

Energy prices in some areas are based on peak and offpeak demand. This pricing variation can be an important factor in developing cost-effective and energy-efficient SDI systems, but it has been often ignored in system design. For example, peak energy costs in the California Central Valley occur between 4:00 to 9:00 p.m., and therefore there is an incentive to pause irrigation during this time of the day. System designs need the flexibility to apply needed water at the best available time as well as the automation capability to make such adjustments. This timing can be further complicated by water resources that involve delivery schedules (e.g., canals and aqueducts).

Many SDI system designs that are based only on crop needs will be inadequate for these more complex scenarios. In deep soils with good water-holding capacity and for deeprooted crops, the minimized evaporation losses and excellent distribution uniformity can make SDI a desirable choice when irrigation is interrupted. This need for flexibility is also a big incentive for the development of robust monitoring and control systems that can assess plant and soil water status and make adjustments in a timely fashion.

\section{Challenges AND OPPORTUNITIES FOR SDI OPERATION AND MANAGEMENT}

Initially, installation of a smaller SDI system can help producers gain experience with SDI operation and management, but paradoxically this approach may not lead to successful adoption of SDI because producers with limited available time may be unwilling to spend the time necessary to learn a small system. Operation of an SDI system is not beyond the range of skills of a typical producer, but it requires different management and more timely and consistent management. For example, the inherent nature of SDI systems of applying irrigation below the soil surface removes many of the visual cues of system operation, such as wetting of the soil surface.

The resistance of producers to adopt more complex management strategies remains a persistent impediment to SDI adoption and was identified as early as 1996 by Phene (1996). Continued advances in sensor data collection, management, and analysis, e.g., closed-loop systems and internet of things (IoT), will help in developing robust systems and monitoring strategies that could remove this impediment. Improved characterization of the soil water content (in two or three dimensions) with better soil water sensors and/or modeling could help irrigation managers apply water at "just the right place and at just the right time." This would further reduce non-beneficial water losses, increase application efficiency, and help achieve a more suitable soil water distribution for crop needs.

As with any irrigation system, as SDI management becomes more complex, the need for a skilled workforce increases. Some producers are unwilling to invest time and labor resources in managing and troubleshooting SDI systems; in such cases, alternative irrigation systems are a preferred choice. As producer knowledge of SDI increases, more complex operation and management will become desirable to optimize crop production while minimizing unnecessary use of inputs. This intensification of production will involve conjunctive management of SDI, agrochemicals, cultivar selection, and cultural practices. Many of these intensification strategies have been developed for higher-value crops (i.e., fruits, vegetables, trees, and vines), but many still need to be developed for lesser-value crops (i.e., grains, oilseeds, fiber, and forage).

The continued search for more sustainable irrigation systems provides opportunities for SDI as an efficient delivery method with greater uniformity of crop production (i.e., more similar plants). Additional environmental benefits of SDI will likely include the aforementioned reduction in GHG emissions and reductions in pathogen exposure routes, and these combined environmental benefits may become an important overall reason for SDI adoption.

\section{Challenges AND OPPORTUNITIES FOR CROPPING WITH SDI}

Crop germination and establishment remain a persistent problem for SDI in semi-arid and arid regions where precipitation near the planting window is sparse. This is particularly a problem for crops with small seeds, such as cotton, that need to be planted at a shallow depth. Irregular crop stands caused by differential germination can reduce yields both spatially, by not having enough plants, and temporally, by having too much interplant competition (i.e., shading of late-emerging plants that limits yield).

As discussed earlier for the design and installation challenges of SDI systems, crop rotation can be problematic with SDI when the crop row spacing does not match well with the ability of SDI to wet the crop root zone. Similarly, in regions where saline soil or water can be a problem, high salinity zones at the edges of the SDI wetting pattern can decimate crop production if the crop rows are not carefully managed. Leaching with SDI is difficult, if not impossible, so an alternative means of providing periodic leaching (e.g., SprI or SGI) may be required in arid regions. In some cases, the saline soil can be displaced to the crop interrow with tillage.

Some crops have achieved appreciable yield increases (e.g., cotton and processing tomato) or improvements in quality (e.g., onions) with SDI that have justified its adoption. Other crops have not shown yield increases (e.g., grain sorghum) or sufficient yield increases (e.g., some crop rotations) to justify SDI over alternative irrigation systems. The SDI 
adoption rationale for some crops is well understood and documented, while further evaluation is warranted for other crops, particularly when crop rotation is prevalent. For example, opportunities may exist to change irrigation strategies and management when using SDI for a certain crop. This may be an emerging opportunity to better understand crop physiology related to water stress and to exploit changes in cultivars occurring through seed company genetics.

\section{Challenges ANd OPPORTUNities FOR SDI MAINTENANCE}

Damage to drip laterals caused by rodent gnawing and other animal activity remains one of the most intractable maintenance challenges for SDI systems. Damage to laterals by field equipment has also been a challenge but has been mostly resolved in the past 20 years by the use of GPS guidance systems. Significant time and labor are required to repair system leaks due to damage by animals. Most repairs are needed at the beginning of the irrigation season, when the SDI system is first activated, due to rodents burrowing below the soil surface during the winter. This problem may be exacerbated in semi-arid and arid regions that have heavy soils at the surface that are prone to cracking, especially if winters are dry, because the cracks in the soil provide an easier path for rodents to reach the SDI laterals. Labor to repair leaks may also be required throughout the irrigation season to maintain the SDI emission uniformity.

There is substantial anecdotal evidence that rodent activity is further increased if crop residue is left on the soil surface, which results in a more favorable rodent habitat. As stated earlier (Sorensen, 2019), removal of peanut foliage resulted in reduced rodent damage to SDI driplines. At the USDA-ARS laboratory in Bushland, Texas, nearly 50 labor $\mathrm{h} \mathrm{ha}^{-1}$ was needed to repair SDI driplines after fallowing with wheat stubble in the previous summer, fall, and winter. At a commercial scale, such extensive damage would likely result in the SDI system being abandoned. As a result, adoption of SDI may discourage concurrent adoption of reduced-tillage or no-tillage production. Thus, a hidden maintenance cost may include increased tillage requirements for producers who would otherwise practice reduced tillage or no tillage, or selective crop rotation strategies that involve fallowing. Further, the benefits of maintaining crop residue (e.g., enhanced precipitation capture, reduced soil water evaporation, and reduced soil erosion by wind and water) may be perceived as outweighing the benefits of SDI. Development of robust, safe (i.e., no or low toxicity), and economical strategies to reduce rodent damage is of paramount concern for reducing impediments to SDI adoption.

As with any microirrigation system, clogging of SDI emitters remains a concern. Historically, clogging problems and solutions for microirrigation systems have followed a pattern in the U.S. As system adoption starts in a region, generally the only resources that exist to solve an emerging clogging problem are from another region that previously adopted the system, and sometimes the solution is quite old and not well documented for current needs. Normally, the solution was generated in the previous region only after sufficient adoption of microirrigation had occurred (i.e., expertise became involved in solving the problem only when the microirrigated area had increased). The solution may have been successful, but it may also be specific to the previous region's water conditions (i.e., the concentrations of physical, chemical, and biological constituents) and may not be applicable in another region. In addition, the expertise responsible for the solution in the previous region may no longer be available. As a result, the pattern starts again in the next region of microirrigation adoption. Opportunities exist for much better documentation of clogging solutions and better generalizations of such solutions.

Although the maintenance challenges can be considerable with SDI compared with alternative systems, SDI can avoid some problems experienced with alternative systems. For example, SDI systems generally are not subject to wind or tornadic damage, do not experience normal wear and tear on moving parts, do not experience flat or stuck tires, or tower alignment or guidance issues, and are not subject to theft of copper wiring, as with CP systems. Maintenance procedures for SDI can often be handled by on-farm staff, rather than requiring a service call from an irrigation dealer. Additionally, CP systems often have proprietary software or hardware that requires dealer service.

\section{SUMMARY AND CONCLUSIONS}

The SDI irrigated land area continues to expand in the U.S., and SDI is being adopted for multiple types of crops (fiber, grain and oilseed, horticultural, forage, and turf). The rationales for SDI adoption and the pace of adoption vary and are of course heavily affected by the prevailing economics. Much of the results from SDI research are what might be anticipated for an irrigation system that can inherently and efficiently apply small amounts of water within the crop root zone as needed, thus reducing non-beneficial water losses. This review highlights research progress within the U.S. during the past decade, and the research suggests that further advances will occur in the future. Challenges remain to successful commercial adoption of SDI, but opportunities also exist. Some challenges are being addressed by universities, federal and state agencies, and industry. Overall, one of the greatest challenges for SDI nationwide is the prevention and mitigation of rodent damage to subsurface driplines. Research is needed to address this challenge. Conversely, a broad array of opportunities exists for SDI systems, and the opportunities are likely to expand further as irrigation sustainability and world food issues become more important.

\section{ACKNOWLEDGEMENTS}

Contribution No. 21-231-J from the Kansas Agricultural Experiment Station. This work was supported by the USDA National Institute of Food and Agriculture, Hatch Multistate Project 1021229 (W-4128: Microirrigation: A Sustainable Technology for Crop Intensification and Improved Water Productivity); by the USDA-ARS Ogallala Aquifer Program, a consortium between the USDA-ARS, Kansas State University, Texas A\&M AgriLife Research, Texas A\&M AgriLife Extension, Texas Tech University, and West Texas A\&M University; by USDA-ARS National Program 211, Water Availability and Watershed Management; and by the 
Alabama Agricultural Experiment Station and the USDANIFA Hatch Program. The SDI sunflower research work mentioned in this article was partially supported through a grant from the U.S. National Science Foundation (Award No. 1444522). This research was also financially supported by Netafim Irrigation, the Alabama Cotton Commission, the Alabama Wheat and Feed Grains Commission, the Alabama Peanut Producers Association, and the National Peanut Board. Portions of the presented research were funded by the USDA-NIFA Ogallala Water CAP 2016-68007-25066, the Texas State Support Committee of Cotton Incorporated, and USDA-NIFA Hatch Project 1007927 through Texas A\&M AgriLife Research. The senior author would like to thank Ms. Vicki Brown at the Kansas State University Northwest Research-Extension Center for her extensive efforts in managing the list of references.

\section{REFERENCES}

AbdelGadir, A. H., Fulton, J. P., Dougherty, M., Curtis, L. M., van Santen, E., Burmester, C. H., ... Norris, B. E. (2011). Subsurface drip irrigation placement and cotton irrigation water requirement in the Tennessee Valley. Crop Mgmt., 10(1), 1-10.

https://doi.org/10.1094/CM-2011-0819-01-RS

Allen, V. G., Brown, C. P., Kellison, R., Green, P., Zilverberg, C. J., Johnson, P., ... Conkwright, J. C. (2012). Integrating cotton and beef production in the Texas Southern High Plains: I. Water use and measures of productivity. Agron. J., 104(6), 1625-1642. https://doi.org/10.2134/agronj2012.0121

Arbat, G. P., Lamm, F. R., \& Abou Kheira, A. A. (2010). Subsurface drip irrigation emitter spacing effects on soil water redistribution, corn yield, and water productivity. Appl. Eng. Agric., 26(3), 391-399. https://doi.org/10.13031/2013.29959

ASABE. (2019). S526.4: Soil and water terminology. St. Joseph, MI: ASABE.

Attia, A., \& Rajan, N. (2016). Within-season growth and spectral reflectance of cotton and their relation to lint yield. Crop Sci., 56(5), 2688-2701. https://doi.org/10.2135/cropsci2015.05.0296

Attia, A., Rajan, N., Nair, S. S., DeLaune, P. B., Xue, Q., Ibrahim, A. M., \& Hays, D. B. (2016). Modeling cotton lint yield and water use efficiency responses to irrigation scheduling using Cotton2K. Agron. J., 108(4), 1614-1623. https://doi.org/10.2134/agronj2015.0437

Attia, A., Rajan, N., Ritchie, G., Cui, S., Ibrahim, A., Hays, D., ... Wilborn, J. (2015). Yield, quality, and spectral reflectance responses of cotton under subsurface drip irrigation. Agron. J., 107(4), 1355-1364. https://doi.org/10.2134/agronj14.0502

Ayars, J. E., Fulton, A., \& Taylor, B. (2015). Subsurface drip irrigation in California: Here to stay? Agric. Water Mgmt., 157, 39-47. https://doi.org/10.1016/j.agwat.2015.01.001

Ayars, J. E., Phene, C. J., Phene, R. C., Gao, S., Wang, D., Day, K. R., \& Makus, D. J. (2017). Determining pomegranate water and nitrogen requirements with drip irrigation. Agric. Water Mgmt., 187, 11-23. https://doi.org/10.1016/j.agwat.2017.03.007

Baker, J. T., Gitz, D. C., Stout, J. E., \& Lascano, R. J. (2015). Cotton water use efficiency under two different deficit irrigation scheduling methods. Agron., 5(3), 363-373. https://doi.org/10.3390/agronomy5030363

Baker, J. T., Mahan, J. R., Gitz, D. C., Lascano, R. J., \& Ephrath, J. E. (2013). Comparison of deficit irrigation scheduling methods that use canopy temperature measurements. Plant Biosyst., 147(1), 40-49. https://doi.org/10.1080/11263504.2012.736423

Barnaby, J. Y., Rohila, J. S., Henry, C. G., Sicher, R. C., Reddy, V. R., \& McClung, A. M. (2019). Physiological and metabolic responses of rice to reduced soil moisture: Relationship of water stress tolerance and grain production. Intl. J. Molec. Sci., 20(8), 1846. https://doi.org/10.3390/ijms20081846

Barnes, E. M., Campbell, B. T., Vellidis, G., Porter, W., Payero, J., Leib, B., ... Thorp, K. (2020). Forty years of increasing cotton's water productivity and why the trend will continue. Appl. Eng. Agric., 36(4), 457-478. https://doi.org/10.13031/aea.13911

Beggs, R. A., Hills, D. J., Tchobanoglous, G., \& Hopmans, J. W. (2011). Fate of nitrogen for subsurface drip dispersal of effluent from small wastewater systems. J. Contam. Hydrol., 126(1-2), 19-28. https://doi.org/10.1016/j.jconhyd.2011.05.007

Bern, C. R., Breit, G. N., Healy, R. W., \& Zupancic, J. W. (2013a). Deep subsurface drip irrigation using coal-bed sodic water: Part II. Geochemistry. Agric. Water Mgmt., 118, 135-149. https://doi.org/10.1016/j.agwat.2012.11.013

Bern, C. R., Breit, G. N., Healy, R. W., Zupancic, J. W., \& Hammack, R. (2013b). Deep subsurface drip irrigation using coal-bed sodic water: Part I. Water and solute movement. Agric. Water Mgmt., 118, 122-134. https://doi.org/10.1016/j.agwat.2012.11.014

Bhattarai, B., Singh, S., West, C. P., Ritchie, G. L., \& Trostle, C. L. (2020). Water depletion pattern and water use efficiency of forage sorghum, pearl millet, and corn under water-limiting condition. Agric. Water Mgmt., 238, 106206. https://doi.org/10.1016/j.agwat.2020.106206

Bordovsky, J. P. (2020). Preplant and early-season cotton irrigation timing with deficit amounts using subsurface drip (SDI) systems in the Texas High Plains. Irrig. Sci., 38(5), 485-499. https://doi.org/10.1007/s00271-019-00661-3

Bordovsky, J. P., \& Mustian, J. T. (2012). Cotton response to crop row offset and orientation to subsurface drip irrigation laterals. Appl. Eng. Agric., 28(3), 367-376. https://doi.org/10.13031/2013.41496

Bordovsky, J. P., \& Mustian, J. T. (2020). Evaluation of cotton establishment strategies using subsurface drip irrigation (SDI) in the Southern High Plains of Texas. Appl. Eng. Agric., 36(6), 891-904. https://doi.org/10.13031/aea.14098

Bronson, K. F., Hunsaker, D. J., Meisinger, J. J., Rockholt, S. M., Thorp, K. R., Conley, M. M., ... Barnes, E. M. (2019). Improving nitrogen fertilizer use efficiency in subsurface dripirrigated cotton in the desert Southwest. SSSA J., 83(6), 17121721. https://doi.org/10.2136/sssaj2019.07.0210

Bronson, K. F., Hunsaker, D. J., Williams, C. F., Thorp, K. R., Rockholt, S. M., Del Grosso, S. J., ... Barnes, E. M. (2018). Nitrogen management affects nitrous oxide emissions under varying cotton irrigation systems in the desert Southwest, USA. J. Environ. Qual., 47(1), 70-78. https://doi.org/10.2134/jeq2017.10.0389

Bronson, K. F., Malapati, A., Scharf, P. C., \& Nichols, R. L. (2011). Canopy reflectance-based nitrogen management strategies for subsurface drip irrigated cotton in the Texas High Plains. Agron. J., 103(2), 422-430. https://doi.org/10.2134/agronj2010.0161

Bufon, V. B., Lascano, R. J., Bednarz, C., Booker, J. D., \& Gitz, D. C. (2012). Soil water content on drip-irrigated cotton:

Comparison of measured and simulated values obtained with the Hydrus 2-D model. Irrig. Sci., 30(4), 259-273. https://doi.org/10.1007/s00271-011-0279-z

Burke, J. J., \& Ulloa, M. (2017). Stress responses of commercial cotton cultivars to reduced irrigation at flowering and maximization of yields under sub-optimal subsurface drip irrigation. J. Cotton Sci., 21(3), 229-241.

Cabrera, J. A., Wang, D., Schneider, S. M., \& Hanson, B. D. (2012). Subsurface drip application of alternative fumigants to methyl bromide for controlling nematodes in replanted grapevines. Pest Mgmt. Sci., 68(5), 773-780. https://doi.org/10.1002/ps.2325 
Camp, C. R. (1998). Subsurface drip irrigation: A review. Trans. ASAE, 41(5), 1353-1367. https://doi.org/10.13031/2013.17309

Camp, C. R., Lamm, F. R., Evans, R. G., \& Phene, C. J. (2000). Subsurface drip irrigation: Past, present, and future. In R. G. Evans, B. L. Benham, \& T. P. Trooien (Ed.), Proc. 4th Decennial National Irrigation Symp. (pp. 363-372). St. Joseph, MI: ASAE.

Chakraborty, M., Khot, L. R., Sankaran, S., \& Jacoby, P. W. (2019). Evaluation of mobile 3D light detection and ranging based canopy mapping system for tree fruit crops. Comput. Electron. Agric., 158, 284-293. https://doi.org/10.1016/j.compag.2019.02.012

Chastain, D. R., Snider, J. L., Choinski, J. S., Collins, G. D., Perry, C. D., Whitaker, J., ... Porter, W. (2016b). Leaf ontogeny strongly influences photosynthetic tolerance to drought and high temperature in Gossypium hirsutum. J. Plant Physiol., 199, 1828. https://doi.org/10.1016/j.jplph.2016.05.003

Chastain, D. R., Snider, J. L., Collins, G. D., Perry, C. D., Whitaker, J., Byrd, S. A., ... Porter, W. M. (2016a). Irrigation scheduling using predawn leaf water potential improves water productivity in drip-irrigated cotton. Crop Sci., 56(6), 3185-3195. https://doi.org/10.2135/cropsci2016.01.0009

Chatterjee, S., Irmak, S., Payero, J. O., Kilic, A., Odhiambo, L. O., Rudnick, D., ... Billesbach, D. (2019). Correction to: "On the magnitude and dynamics of eddy covariance system residual energy (energy balance closure error) in subsurface dripirrigated maize field during growing and non-growing (dormant) seasons." Irrig. Sci., 37(6), 761-761. 10.1007/s00271-01900645-3

Chavez, J. C., Enciso, J., Ganjegunte, G., Rajan, N., Jifon, J., \& Singh, V. P. (2019). Growth response and productivity of sorghum for bioenergy production in south Texas. Trans. ASABE, 62(5), 1207-1218. https://doi.org/10.13031/trans.13317

Davis, S. (1974). History of drip irrigation. Agribusiness News, 10(7), 1.

DeLaune, P. B., Mubvumba, P., Ale, S., \& Kimura, E. (2020). Impact of no-till, cover crop, and irrigation on cotton yield. Agric. Water Mgmt., 232, 106038. https://doi.org/10.1016/j.agwat.2020.106038

DeLaune, P. B., Sij, J. W., Park, S. C., \& Krutz, L. J. (2012). Cotton production as affected by irrigation level and transitioning tillage systems. Agron. J., 104(4), 991-995. https://doi.org/10.2134/agronj2011.0420

Diotto, A. V., \& Irmak, S. (2016). Embodied energy and energy return on investment analyses in maize production for grain and ethanol under center pivot, subsurface drip, and surface (furrow) irrigation with disk tillage and no-till practices. Trans. ASABE, 59(3), 873-884. https://doi.org/10.13031/trans.59.11331

El-Nesr, M. N., Alazba, A. A., \& Šimůnek, J. (2014). HYDRUS simulations of the effects of dual-drip subsurface irrigation and a physical barrier on water movement and solute transport in soils. Irrig. Sci., 32(2), 111-125. https://doi.org/10.1007/s00271-0130417-x

Elsayed-Farag, S., Anciso, J., Marconi, C., Avila, C., Rodriguez, A., Badillo-Vargas, I. E., \& Enciso, J. (2018). Appropriate planting dates and plastic mulch for increasing common tomato varieties yield in south Texas. African J. Agric. Res., 13(26), 1349-1357. https://doi.org/10.5897/AJAR2018.13212

Eltarabily, M. G., Bali, K. M., Negm, A. M., \& Yoshimura, C. (2019a). Evaluation of root water uptake and urea fertigation distribution under subsurface drip irrigation. Water, 11(7), 1487. https://doi.org/10.3390/w11071487

Eltarabily, M. G., Burke, J. M., \& Bali, K. M. (2019b). Effect of deficit irrigation on nitrogen uptake of sunflower in the low desert region of California. Water, 11(11), 2340.

https://doi.org/10.3390/w11112340
Eltarabily, M. G., Burke, J. M., \& Bali, K. M. (2020). Impact of deficit irrigation on shallow saline groundwater contribution and sunflower productivity in the Imperial Valley, California. Water, 12(2), 571. Retrieved from https://www.mdpi.com/2073$4441 / 12 / 2 / 571$

Enciso, J., Avila, C. A., Jung, J., Elsayed-Farag, S., Chang, A., Yeom, J., ... Chavez, J. C. (2019). Validation of agronomic UAV and field measurements for tomato varieties. Comput. Electron. Agric., 158, 278-283.

https://doi.org/10.1016/j.compag.2019.02.011

Enciso, J., Jifon, J., Anciso, J., \& Ribera, L. (2015b). Productivity of onions using subsurface drip irrigation versus furrow irrigation systems with an internet-based irrigation scheduling program. Intl. J. Agron., 2015(178180). https://doi.org/10.1155/2015/178180

Enciso, J., Jifon, J., Ribera, L., Zapata, S. D., \& Ganjegunte, G. K. (2015a). Yield, water use efficiency, and economic analysis of energy sorghum in south Texas. Biomass Bioenergy, 81, 339344. https://doi.org/10.1016/j.biombioe.2015.07.021

Enciso-Medina, J., L. Multer, W., \& R. Lamm, F. (2011). Management, maintenance, and water quality effects on the long-term performance of subsurface drip irrigation systems. Appl. Eng. Agric., 27(6), 969-978. https://doi.org/10.13031/2013.40633

Engle, M. A., Bern, C. R., Healy, R. W., Sams, J. I., Zupancic, J. W., \& Schroeder, K. T. (2011). Tracking solutes and water from subsurface drip irrigation application of coalbed methane produced waters, Powder River basin, Wyoming. Environ. Geosci., 18(3), 169-187. https://doi.org/10.1306/eg.03031111004

Evett, S. R., Colaizzi, P. D., Lamm, F. R., O’Shaughnessy, S. A., Heeren, D. M., Trout, T. J., ... Lin, X. (2020b). Past, present, and future of irrigation on the U.S. Great Plains. Trans. ASABE, 63(3), 703-729. https://doi.org/10.13031/trans.13620

Evett, S. R., Marek, G. W., Colaizzi, P. D., Brauer, D. K., \& O'Shaughnessy, S. A. (2019). Corn and sorghum ET, E, yield, and CWP as affected by irrigation application method: SDI versus mid-elevation spray irrigation. Trans. ASABE, 62(5), 1377-1393. https://doi.org/10.13031/trans.13314

Evett, S. R., Marek, G. W., Colaizzi, P. D., Brauer, D., \& Howell, T. A. (2020a). Are crop coefficients for SDI different from those for sprinkler irrigation application? Trans. ASABE, 63(5), 12331242. https://doi.org/10.13031/trans. 13920

Evett, S. R., Marek, G. W., Colaizzi, P. D., Ruthardt, B. B., \& Copeland, K. S. (2018). A subsurface drip irrigation system for weighing lysimetry. Appl. Eng. Agric., 34(1), 213-221. https://doi.org/10.13031/aea.12597

Feng, L., Mathis, G., Ritchie, G., Han, Y., Li, Y., Wang, G., ... Bednarz, C. W. (2014). Optimizing irrigation and plant density for improved cotton yield and fiber quality. Agron. J., 106(4), 1111-1118. https://doi.org/10.2134/agronj13.0503

Fuentes, C., Enciso, J., Nelson, S. D., Anciso, J., Setamou, M., \& Elsayed-Farag, S. (2018). Yield production and water use efficiency under furrow and drip irrigation systems for watermelon in south Texas. Subtropical Agric. Environ., 69(17), 2018.

Ganjegunte, G., Leinauer, B., Schiavon, M., \& Serena, M. (2013). Using electro-magnetic induction to determine soil salinity and sodicity in turf root zones. Agron. J., 105(3), 836-844. https://doi.org/10.2134/agronj2012.0503

Gao, S., Hendratna, A., Cai, Z., Duan, Y., Qin, R., \& TiradoCorbalá, R. (2019). Subsurface drip irrigation reduced nitrous oxide emissions in a pomegranate orchard. Intl. J. Environ. Sci. Dev., 10(3), 79-85. 
Goebel, T. S., \& Lascano, R. J. (2019). Rainwater use by cotton under subsurface drip and center pivot irrigation. Agric. Water Mgmt., 215, 1-7. https://doi.org/10.1016/j.agwat.2018.12.027

Grabow, G. L., Huffman, R. L., \& Evans, R. O. (2011). SDI dripline spacing effect on corn and soybean yield in a Piedmont clay soil. J. Irrig. Drain. Eng., 137(1), 27-36. https://doi.org/10.1061/(ASCE)IR.1943-4774.0000277

Hall, B. J. (1985). History of drip/trickle irrigation. Proc. 3rd Intl. Drip/Trickle Congress (pp. 1-7). St. Joseph, MI: ASAE.

Harbuck, T. L., Fulton, J. P., Dougherty, M., Taylor, S. T., Eakes, D. J., \& Sibley, J. L. (2011). In-field application uniformity evaluation of pressure-compensating subsurface-drip irrigation products. Appl. Eng. Agric., 27(1), 43-50. https://doi.org/10.13031/2013.36229

Harmoney, K. R., Lamm, F. R., Johnson, S. K., \& Aboukheira, A. A. (2013). Reducing water inputs with subsurface drip irrigation may improve alfalfa nutritive value. Forage Grazinglands, 11(1), 1-8. https://doi.org/10.1094/FG-2013-117-01-RS

He, J., Dougherty, M., \& AbdelGadir, A. (2013c). Numerical assisted assessment of vadose-zone nitrogen transport under a soil moisture controlled wastewater SDI dispersal system in a Vertisol. Ecol. Eng., 53, 228-234. https://doi.org/10.1016/j.ecoleng.2012.12.048

He, J., Dougherty, M., Arriaga, F. J., \& AbdelGadir, A. H. (2013b). Impact of a real-time controlled wastewater subsurface drip disposal system on the selected chemical properties of a vertisol. Environ. Tech., 34(10), 1341-1347. https://doi.org/10.1080/09593330.2012.746737

He, J., Dougherty, M., Arriaga, F. J., Fulton, J. P., Wood, C. W., Shaw, J. N., \& Lange, C. R. (2013a). Short-term soil nutrient impact in a real-time drain field soil moisture-controlled SDI wastewater disposal system. Irrig. Sci., 31(1), 59-67. https://doi.org/10.1007/s00271-011-0292-2

He, J., Dougherty, M., Shaw, J., Fulton, J., \& Arriaga, F. (2011). Hydraulic management of a soil moisture controlled SDI wastewater dispersal system in an Alabama Black Belt soil. $J$. Environ. Mgmt., 92(10), 2479-2485. https://doi.org/10.1016/j.jenvman.2011.05.009

Hollingsworth, J., Mitchell, J. P., Munk, D. S., Roberts, B. A., \& Shrestha, A. (2014). Subsurface drip and overhead irrigation effects on conservation-tilled cotton in the San Joaquin Valley. J. Crop Improvement, 28(3), 324-344. https://doi.org/10.1080/15427528.2014.881449

Hunsaker, D. J., \& Elshikha, D. M. (2017). Surface irrigation management for guayule rubber production in the U.S. desert Southwest. Agric. Water Mgmt., 185, 43-57. https://doi.org/10.1016/j.agwat.2017.01.015

Hunsaker, D. J., Elshikha, D. M., \& Bronson, K. F. (2019). High guayule rubber production with subsurface drip irrigation in the U.S. desert Southwest. Agric. Water Mgmt., 220, 1-12. https://doi.org/10.1016/j.agwat.2019.04.016

Irmak, A., Singh, R. K., Walter-Shea, E. A., Verma, S. B., \& Suyker, A. E. (2011). Comparison and analysis of empirical equations for soil heat flux for different cropping systems and irrigation methods. Trans. ASABE, 54(1), 67-80.

https://doi.org/10.13031/2013.36261

Irmak, S., \& Djaman, K. (2016). Effects of planting date and density on plant growth, yield, evapotranspiration, and water productivity of subsurface drip-irrigated and rainfed maize. Trans. ASABE, 59(5), 1235-1256. https://doi.org/10.13031/trans.59.11169

Irmak, S., Djaman, K., \& Rudnick, D. R. (2016). Effect of full and limited irrigation amount and frequency on subsurface dripirrigated maize evapotranspiration, yield, water use efficiency, and yield response factors. Irrig. Sci., 34(4), 271-286. https://doi.org/10.1007/s00271-016-0502-z
Irmak, S., Payero, J. O., Kilic, A., Odhiambo, L. O., Rudnick, D., Sharma, V., \& Billesbach, D. (2014a). On the magnitude and dynamics of eddy covariance system residual energy (energy balance closure error) in subsurface drip-irrigated maize field during growing and non-growing (dormant) seasons. Irrig. Sci., 32(6), 471-483. https://doi.org/10.1007/s00271-014-0443-3

Irmak, S., Specht, J. E., Odhiambo, L. O., Rees, J. M., \& Cassman, K. G. (2014b). Soybean yield, evapotranspiration, water productivity, and soil water extraction response to subsurface drip irrigation and fertigation. Trans. ASABE, 57(3), 729-748. https://doi.org/10.13031/trans.57.10085

Jacoby, P., \& Ma, X. (2018). Introducing direct root-zone deficit irrigation to conserve water and enhance grape quality in the Pacific Northwest. Crops Soils, 51(5), 34-58. https://doi.org/10.2134/cs2018.51.0510

Johnson, P., Zilverberg, C. J., Allen, V. G., Weinheimer, J., Brown, P., Kellison, R., \& Segarra, E. (2013). Integrating cotton and beef production in the Texas Southern High Plains: III. An economic evaluation. Agron. J., 105(4), 929-937. https://doi.org/10.2134/agronj2012.0465

Jordan, D. L., Johnson, P. D., Grabow, G. L., \& Corbett, T. (2014). Corn, cotton, and peanut response to tillage and subsurface drip irrigation in North Carolina. Agron. J., 106(3), 962-967. https://doi.org/10.2134/agronj13.0486

Kallenbach, C. M., Rolston, D. E., \& Horwath, W. R. (2010). Cover cropping affects soil $\mathrm{N}_{2} \mathrm{O}$ and $\mathrm{CO}_{2}$ emissions differently depending on type of irrigation. Agric. Ecosyst. Environ., 137(3), 251-260. https://doi.org/10.1016/j.agee.2010.02.010

Kandelous, M. M., \& Šimůnek, J. (2010a). Comparison of numerical, analytical, and empirical models to estimate wetting patterns for surface and subsurface drip irrigation. Irrig. Sci., 28(5), 435-444. 10.1007/s00271-009-0205-9

Kandelous, M. M., \& Šimůnek, J. (2010b). Numerical simulations of water movement in a subsurface drip irrigation system under field and laboratory conditions using HYDRUS-2D. Agric. Water Mgmt., 97(7), 1070-1076. https://doi.org/10.1016/j.agwat.2010.02.012

Kandelous, M. M., Kamai, T., Vrugt, J. A., Šimůnek, J., Hanson, B., \& Hopmans, J. W. (2012). Evaluation of subsurface drip irrigation design and management parameters for alfalfa. Agric. Water Mgmt., 109, 81-93. https://doi.org/10.1016/j.agwat.2012.02.009

Kandelous, M. M., Śimůnek, J., van Genuchten, M. T., \& Malek, K. (2011). Soil water content distributions between two emitters of a subsurface drip irrigation system. SSSA J., 75(2), 488-497. https://doi.org/10.2136/sssaj2010.0181

Kennedy, T. L., Suddick, E. C., \& Six, J. (2013). Reduced nitrous oxide emissions and increased yields in California tomato cropping systems under drip irrigation and fertigation. Agric. Ecosyst. Environ., 170, 16-27. https://doi.org/10.1016/j.agee.2013.02.002

Kukal, M. S., \& Irmak, S. (2020). Characterization of water use and productivity dynamics across four $\mathrm{C} 3$ and $\mathrm{C} 4$ row crops under optimal growth conditions. Agric. Water Mgmt., 227, 105840. https://doi.org/10.1016/j.agwat.2019.105840

Lamm, F. R. (2016). Cotton, tomato, corn, and onion production with subsurface drip irrigation: A review. Trans. ASABE, 59(1), 263-278. https://doi.org/10.13031/trans.59.11231

Lamm, F. R., \& Puig-Bargués, J. (2017). Simplified equations to estimate flushline diameter for subsurface drip irrigation systems. Trans. ASABE, 60(1), 185-192. https://doi.org/10.13031/trans.12131

Lamm, F. R., \& Rogers, D. H. (2017). Longevity and performance of a subsurface drip irrigation system. Trans. ASABE, 60(3), 931-939. https://doi.org/10.13031/trans.12237 
Lamm, F. R., Abou Kheira, A. A., \& Trooien, T. P. (2010). Sunflower, soybean, and grain sorghum crop production as affected by dripline depth. Appl. Eng. Agric., 26(5), 873-882. https://doi.org/10.13031/2013.34952

Lamm, F. R., Bordovsky, J. P., Schwankl, L. J., Grabow, G. L., Enciso-Medina, J., Peters, R. T., ... Porter, D. O. (2012a). Subsurface drip irrigation: Status of the technology in 2010. Trans. ASABE, 55(2), 483-491. https://doi.org/10.13031/2013.41387

Lamm, F. R., Harmoney, K. R., Aboukheira, A. A., \& Johnson, S. K. (2012b). Alfalfa production with subsurface drip irrigation in the Central Great Plains. Trans. ASABE, 55(4), 1203-1212. https://doi.org/10.13031/2013.42258

Lamm, F. R., O’Brien, D. M., \& Rogers, D. H. (2015). Economic comparison of subsurface drip and center pivot sprinkler irrigation using spreadsheet software. Appl. Eng. Agric., 31(6), 929-936. https://doi.org/10.13031/aea.31.11253

Leinauer, B., Serena, M., \& Singh, D. (2010). Seed coating and seeding rate effects on turfgrass germination and establishment. HortTech., 20(1), 179-185.

https://doi.org/10.21273/horttech.20.1.179

Li, Y., Allen, V. G., Hou, F., Chen, J., \& Brown, C. P. (2013). Steers grazing a rye cover crop influence growth of rye and notill cotton. Agron. J., 105(6), 1571-1580. https://doi.org/10.2134/agronj2013.0020

Ma, X., Jacoby, P. W., \& Sanguinet, K. A. (2020a). Improving net photosynthetic rate and rooting depth of grapevines through a novel irrigation strategy in a semi-arid climate. Front. Plant Sci., 11, article 1337. https://doi.org/10.3389/fpls.2020.575303

Ma, X., Sanguinet, K. A., \& Jacoby, P. W. (2019). Performance of direct root-zone deficit irrigation on Vitis vinifera L. cv. Cabernet Sauvignon production and water use efficiency in semi-arid southcentral Washington. Agric. Water Mgmt., 221, 47-57. https://doi.org/10.1016/j.agwat.2019.04.023

Ma, X., Sanguinet, K. A., \& Jacoby, P. W. (2020b). Direct rootzone irrigation outperforms surface drip irrigation for grape yield and crop water use efficiency while restricting root growth. Agric. Water Mgmt., 231, 105993. https://doi.org/10.1016/j.agwat.2019.105993

Mitchell, J. P., Shrestha, A., Klonsky, K., Turini, T. A., \& Hembree, K. J. (2014). Overhead and drip irrigation system effects on tomato growth and yield in California's Central Valley. HortTech., 24(6), 637. https://doi.org/10.21273/horttech.24.6.637

Montazar, A., Cahn, M., \& Putman, A. (2019). Research advances in adopting drip irrigation for California organic spinach: Preliminary findings. Agric., 9(8), article 177. https://doi.org/10.3390/agriculture9080177

Montazar, A., Zaccaria, D., Bali, K., \& Putnam, D. (2017). A model to assess the economic viability of alfalfa production under subsurface drip irrigation in California. Irrig. Drain., 66(1), 90102. https://doi.org/10.1002/ird.2091

Murley, C. B., Sharma, S., Warren, J. G., Arnall, D. B., \& Raun, W. R. (2018). Yield response of corn and grain sorghum to row offsets on subsurface drip laterals. Agric. Water Mgmt., 208, 357-362. https://doi.org/10.1016/j.agwat.2018.06.038

Nuti, R. C., Collins, G. D., Jordan, D. L., Corbett, T., Lanier, J. E., Edmisten, K. L., ... Grabow, G. L. (2012). Cotton response to subsurface drip irrigation, planting date, cultivar, and mepiquat chloride. Crop Mgmt., 11(1), 1-9. https://doi.org/10.1094/CM2012-0319-01-RS

Odhiambo, L. O., \& Irmak, S. (2015). Relative evaporative losses and water balance in subsurface drip and center pivot-irrigated soybean fields. J. Irrig. Drain. Eng., 141(11), 04015020. https://doi.org/10.1061/(ASCE)IR.1943-4774.0000907
Odhiambo, L., \& Irmak, S. (2011). Performance of extended Shuttleworth-Wallace model for estimating and partitioning of evapotranspiration in a partial residue-covered subsurface dripirrigated soybean field. Trans. ASABE, 54(3), 915-930. https://doi.org/10.13031/2013.37117

Pabuayon, I. L., Singh, S., Lewis, K. L., \& Ritchie, G. L. (2019). Water extraction and productivity of cotton, sorghum, and sesame under deficit irrigation. Crop Sci., 59(4), 1692-1700. https://doi.org/10.2135/cropsci2019.03.0143

Phene, C. J. (1996). Shovel versus computer. Irrig. Business Tech., 4(3), 6.

Puig-Bargués, J., \& Lamm, F. R. (2013). Effect of flushing velocity and flushing duration on sediment transport in microirrigation driplines. Trans. ASABE, 56(5), 1821-1828.

https://doi.org/10.13031/trans.56.10293

Puig-Bargués, J., Lamm, F. R., Trooien, T. P., \& Clark, G. A. (2010). Effect of dripline flushing on subsurface drip irrigation systems. Trans. ASABE, 53(1), 147-155. https://doi.org/10.13031/2013.29513

Rajan, N., Maas, S. J., \& Kathilankal, J. C. (2010). Estimating crop water use of cotton in the Texas High Plains. Agron. J., 102(6), 1641-1651. https://doi.org/10.2134/agronj2010.0076

Reyes-Cabrera, J., Zotarelli, L., Dukes, M. D., Rowland, D. L., \& Sargent, S. A. (2016). Soil moisture distribution under drip irrigation and seepage for potato production. Agric. Water Mgmt., 169, 183-192.

https://doi.org/10.1016/j.agwat.2016.03.001

Reyes-Cabrera, J., Zotarelli, L., Rowland, D. L., Dukes, M. D., \& Sargent, S. A. (2014). Drip as alternative irrigation method for potato in Florida sandy soils. American J. Potato Res., 91(5), 504-516. https://doi.org/10.1007/s12230-014-9381-0

Reyes-Esteves, R. G., \& Slack, D. C. (2019a). Modeling approaches for determining appropriate depth of subsurface drip irrigation tubing in alfalfa. J. Irrig. Drain. Eng., 145(10), 04019021. https://doi.org/10.1061/(ASCE)IR.1943-4774.0001409

Reyes-Esteves, R. G., \& Slack, D. C. (2019b). Modeling of soil water to ensure a suitable depth and spacing of subsurface drip irrigation for alfalfa. Ing. Agric. Biosistemas, 11(1), 69-79. https://doi.org/10.5154/r.inagbi.2018.02.002

Reyes-Esteves, R. G., \& Slack, D. C. (2021). Closure to modeling approaches for determining appropriate depth of subsurface drip irrigation tubing in alfalfa. J. Irrig. Drain. Eng., 147(1), 07020015. https://doi.org/10.1061/(ASCE)IR.19434774.0001528

Saefuddin, R., Saito, H., \& Šimůnek, J. (2019). Experimental and numerical evaluation of a ring-shaped emitter for subsurface irrigation. Agric. Water Mgmt., 211, 111-122. https://doi.org/10.1016/j.agwat.2018.09.039

Sandhu, R., \& Irmak, S. (2019). Assessment of AquaCrop model in simulating maize canopy cover, soil water, evapotranspiration, yield, and water productivity for different planting dates and densities under irrigated and rainfed conditions. Agric. Water Mgmt., 224, 105753. https://doi.org/10.1016/j.agwat.2019.105753

Schiavon, M., Leinauer, B., Serena, M., Maier, B., \& Sallenave, R. (2014a). Plant growth regulator and soil surfactants' effects on saline and deficit-irrigated warm-season grasses: I. Turf quality and soil moisture. Crop Sci., 54(6), 2815-2826.

https://doi.org/10.2135/cropsci2013.10.0707

Schiavon, M., Leinauer, B., Serena, M., Maier, B., \& Sallenave, R. (2014b). Plant growth regulator and soil surfactants' effects on saline and deficit-irrigated warm-season grasses: II. Pigment content and superoxide dismutase activity. Crop Sci., 54(6), 2827-2836. https://doi.org/10.2135/cropsci2013.10.0708

Schiavon, M., Leinauer, B., Serena, M., Sallenave, R., \& Maier, B. (2012). Bermudagrass and seashore Paspalum establishment 
from seed using differing irrigation methods and water qualities. Agron. J., 104(3), 706-714.

https://doi.org/10.2134/agronj2011.0390

Schiavon, M., Leinauer, B., Serena, M., Sallenave, R., \& Maier, B. (2013). Establishing tall fescue and Kentucky bluegrass using subsurface irrigation and saline water. Agron. J., 105(1), 183190. https://doi.org/10.2134/agronj2012.0187

Schiavon, M., Leinauer, B., Sevastionova, E., Serena, M., \& Maier, B. (2011). Warm-season turfgrass quality, spring green-up, and fall color retention under drip irrigation. Appl. Turfgrass Sci., 8(1), 1-9. https://doi.org/10.1094/ATS-2011-0422-01-RS

Schiavon, M., Serena, M., Leinauer, B., Sallenave, R., \& Baird, J. H. (2015). Seeding date and irrigation system effects on establishment of warm-season turfgrasses. Agron. J., 107(3), 880-886. https://doi.org/10.2134/agronj14.0322

Schmidt, J. E., Peterson, C., Wang, D., Scow, K. M., \& Gaudin, A. C. (2018). Agroecosystem tradeoffs associated with conversion to subsurface drip irrigation in organic systems. Agric. Water Mgmt., 202, 1-8. https://doi.org/10.1016/j.agwat.2018.02.005

Serena, M., Leinauer, B., Schiavon, M., Maier, B., \& Sallenave, R. (2014). Establishment and rooting response of bermudagrass propagated with saline water and subsurface Irrigation. Crop Sci., 54(2), 827-836.

https://doi.org/10.2135/cropsci2013.07.0512

Serena, M., Schiavon, M., Sallenave, R., \& Leinauer, B. (2017a). Nitrogen fertilization of warm-season turfgrasses irrigated with saline water from varying irrigation systems. 1. Quality, spring green-up, and fall colour retention. J. Agron. Crop Sci., 204(3), 252-264. https://doi.org/10.1111/jac. 12254

Serena, M., Schiavon, M., Sallenave, R., \& Leinauer, B. (2017b). Nitrogen fertilization of warm-season turfgrasses irrigated from varying irrigation systems: 2 . Carbohydrate and protein content. J. Agron. Crop Sci., 204(3), 265-273. https://doi.org/10.1111/jac. 12256

Serena, M., Schiavon, M., Sallenave, R., \& Leinauer, B. (2020). Drought avoidance of warm-season turfgrasses affected by irrigation system, soil surfactant revolution, and plant growth regulator trinexapac-ethyl. Crop Sci., 60(1), 485-498. https://doi.org/10.1002/csc2.20063

Sevostianova, E., \& Leinauer, B. (2014). Subsurface-applied tailored water: Combining nutrient benefits with efficient turfgrass irrigation. Crop Sci., 54(5), 1926-1938. https://doi.org/10.2135/cropsci2014.01.0014

Sevostianova, E., Leinauer, B., Sallenave, R., Karcher, D., \& Maier, B. (2011a). Soil salinity and quality of sprinkler and drip irrigated cool-season turfgrasses. Agron. J., 103(5), 1503-1513. https://doi.org/10.2134/agronj2011.0162

Sevostianova, E., Leinauer, B., Sallenave, R., Karcher, D., \& Maier, B. (2011b). Soil salinity and quality of sprinkler and drip irrigated warm-season turfgrasses. Agron. J., 103(6), 1773-1784. https://doi.org/10.2134/agronj2011.0163

Sharma, H., Shukla, M. K., Bosland, P. W., \& Steiner, R. (2017). Soil moisture sensor calibration, actual evapotranspiration, and crop coefficients for drip-irrigated greenhouse chile peppers. Agric. Water Mgmt., 179, 81-91. https://doi.org/10.1016/j.agwat.2016.07.001

Sharma, H., Shukla, M. K., Bosland, P. W., \& Steiner, R. L. (2015). Physiological responses of greenhouse-grown drip-irrigated chile pepper under partial root zone drying. HortSci., 50(8), 1224-1229. https://doi.org/10.21273/hortsci.50.8.1224

Sharma, P., Shukla, M. K., Sammis, T. W., \& Adhikari, P. (2012). Nitrate-nitrogen leaching from onion bed under furrow and drip irrigation systems. Appl. Environ. Soil Sci., 2012, 650206. https://doi.org/10.1155/2012/650206

Sharma, S. P., Leskovar, D. I., Crosby, K. M., Volder, A., \& Ibrahim, A. M. H. (2014). Root growth, yield, and fruit quality responses of reticulatus and inodorus melons (Cucumis melo L.) to deficit subsurface drip irrigation. Agric. Water Mgmt., 136, 75-85. https://doi.org/10.1016/j.agwat.2014.01.008

Sharma, S. P., Leskovar, D. I., Volder, A., Crosby, K. M., \& Ibrahim, A. M. H. (2018). Root distribution patterns of reticulatus and inodorus melon (Cucumis melo L.) under subsurface deficit irrigation. Irrig. Sci., 36(6), 301-317. https://doi.org/10.1007/s00271-018-0587-7

Shock, C. C., Feibert, E. B., Riveira, A., \& Saunders, L. D. (2015). Response of onion yield, grade, and financial return to plant population and irrigation system. HortSci., 50(9), 1312-1318. https://doi.org/10.21273/hortsci.50.9.1312

Shock, C. C., Reitz, S. R., Roncarati, R. A., Kreeft, H., Shock, B. M., \& Klauzer, J. C. (2016). Drip vs. furrow irrigation in the delivery of Escherichia coli to onions. Appl. Eng. Agric., 32(2), 235-244. https://doi.org/10.13031/aea.32.11163

Siegrist, R. L., Parzen, R., Tomaras, J., \& Lowe, K. S. (2014). Water movement and fate of nitrogen during drip dispersal of wastewater effluent into a semi-arid landscape. Water Res., 52, 178-187. https://doi.org/10.1016/j.watres.2013.12.031

Sij, J. W., Bordovsky, D. G., Jones, D. L., \& Slosser, J. E. (2010). Utilizing subsurface drip irrigation and conservation tillage in cotton production systems. SRX Agric., 2010, 725381. https://doi.org/10.3814/2010/725381

Skaggs, K. E., \& Irmak, S. (2011). Characterization of nighttime evapotranspiration and other surface energy fluxes and interactions with microclimatic variables in subsurface drip and center-pivot irrigated soybean fields. Trans. ASABE, 54(3), 941952. https://doi.org/10.13031/2013.37119

Skaggs, T. H., Trout, T. J., \& Rothfuss, Y. (2010). Drip irrigation water distribution patterns: Effects of emitter rate, pulsing, and antecedent water. SSSA J., 74(6), 1886-1896.

https://doi.org/10.2136/sssaj2009.0341

Slack, D. C., Esteves, R. R., Espejel, A., Oyorsaval, B., \& Ma, Y. (2017). Subsurface drip irrigation: A technology for safer irrigation of vegetable crops. Eng. Appl. Sci. Res., 44(2), 111114.

Snowden, C., Ritchie, G., \& Thompson, T. (2013a). Water use efficiency and irrigation response of cotton cultivars on subsurface drip in west Texas. J. Cotton Sci., 17(1), 1-9.

Snowden, C., Ritchie, G., Cave, J., Keeling, W., \& Rajan, N. (2013b). Multiple irrigation levels affect boll distribution, yield, and fiber micronaire in cotton. Agron. J., 105(6), 1536-1544. https://doi.org/10.2134/agronj2013.0084

Snowden, M. C., Ritchie, G. L., Simao, F. R., \& Bordovsky, J. P. (2014). Timing of episodic drought can be critical in cotton. Agron. J., 106(2), 452-458. https://doi.org/10.2134/agronj2013.0325

Sorensen, R. B. (2019). Removing peanut foliage adjacent shallow subsurface drip laterals to reduce rodent damage. Crop Forage Turfgrass Mgmt., 5(1), 190010. https://doi.org/10.2134/cftm2019.01.0010

Sorensen, R. B., \& Butts, C. L. (2014). Peanut response to crop rotation, drip tube lateral spacing, and irrigation rates with deep subsurface drip irrigation. Peanut Sci., 41(2), 111-119. https://doi.org/10.3146/ps13-19.1

Sorensen, R. B., \& Lamb, M. C. (2015). Longevity of shallow subsurface drip irrigation tubing under three tillage practices. Crop Forage Turfgrass Mgmt., 1(1). https://doi.org/10.2134/cftm2014.0097

Sorensen, R. B., \& Lamb, M. C. (2016). Crop yield response to increasing biochar rates. J. Crop Improvement, 30(6), 703-712. https://doi.org/10.1080/15427528.2016.1231728

Sorensen, R. B., \& Lamb, M. C. (2019). Three soil water potential strategies to schedule irrigation events using $\mathrm{S}^{3} \mathrm{DI}$ in cotton. $J$. Cotton Sci., 23(1), 14-20. 
Sorensen, R. B., \& Nuti, R. C. (2011). Fertilization of peanut with selenium. Peanut Science, 38(1), 26-30. https://doi.org/10.3146/ps10-13.1

Sorensen, R. B., Brenneman, T. B., \& Lamb, M. C. (2010a). Peanut yield response to conservation tillage, winter cover crop, peanut cultivar, and fungicide applications. Peanut Sci., 37(1), 44-51. https://doi.org/10.3146/ps08-004.1

Sorensen, R. B., Butts, C. L., \& Lamb, M. C. (2013). Corn yield response to deep subsurface drip irrigation in the Southeast. Crop Mgmt., 12(1), CM-2013-0122-01-RS. https://doi.org/10.1094/CM-2013-0122-01-RS

Sorensen, R. B., Butts, C. L., \& Nuti, R. C. (2011). Deep subsurface drip irrigation for cotton in the Southeast. J. Cotton Sci., 15(3), 233-242.

Sorensen, R. B., Lamb, M. C., \& Butts, C. L. (2020). Crop rotation, irrigation system, and irrigation rate on cotton yield in southwestern Georgia. Crop Forage Turfgrass Mgmt., 6(1), e20053. https://doi.org/10.1002/cft2.20053

Sorensen, R. B., Lamb, M. C., \& Butts. C., L. (2016). Yield response and economics of shallow subsurface drip irrigation systems. Agric. Sci., 4(1), 1-11. https://doi.org/10.1094/CM2010-1220-01-RS

Sorensen, R. B., Lamb, M. C., Nuti, R. C., \& Butts, C. L. (2012). Corn yield and economic return with nitrogen applied through drip tubing. Crop Mgmt., 11(1), 1-10. https://doi.org/10.1094/CM-2012-0127-01-RS

Sorensen, R. B., Nuti, R. C., \& Lamb, M. C. (2007). Rodent management for surface drip irrigation tubing in corn, cotton, and peanut. Peanut Sci., 34(1), 32-37. https://doi.org/10.3146/0095-3679(2007)34[32:rmfsdi]2.0.co;2

Sorensen, R. B., Nuti, R. C., \& Lamb, M. C. (2010b). Yield and economics of shallow subsurface drip irrigation $\left(\mathrm{S}^{3} \mathrm{DI}\right)$ and furrow diking. Crop Mgmt., 9(1), 1-10. https://doi.org/10.1094/CM-2010-1220-01-RS

Spivey, T. A., Edmisten, K. L., Wells, R., Jordan, D., Heitman, J. L., \& Wilkerson, G. G. (2019). Agronomy and soils: Cotton development and yield response to irrigation, planting date, and cultivar in North Carolina. J. Cotton Sci., 23(2), 148-160.

Spurgeon, W. E., \& Yonts, C. D. (2013). Water productivity of corn and dry bean rotation on very fine sandy loam soil in western Nebraska. Appl. Eng. Agric., 29(6), 885-892. https://doi.org/10.13031/aea.29.9872

Tindula, G. N., Orang, M. N., \& Snyder, R. L. (2013). Survey of irrigation methods in California in 2010. J. Irrig. Drain. Eng., 139(3), 233-238. https://doi.org/10.1061/(ASCE)IR.19434774.0000538

Tirado-Corbalá, R., Gao, S., Ayars, J. E., Wang, D., Phene, C. J., \& Phene, R. C. (2019). Carbon and nitrogen dynamics affected by drip irrigation methods and fertilization practices in a pomegranate orchard. Horticulturae, 5(4), article 77. https://doi.org/10.3390/horticulturae5040077

USDA-NASS. (2004). Farm and ranch irrigation survey (2003). 2002 Census of Agriculture, Vol. 3, Special Studies, Part 1 (AC02-SS-1). Washington, DC : USDA National Agricultural Statistics Service.

USDA-NASS. (2010). Farm and ranch irrigation survey (2008). 2007 Census of Agriculture, Vol. 3, Special Studies, Part 1 (AC-
07-SS-1). Washington, DC: USDA National Agricultural Statistics Service.

USDA-NASS. (2014). Farm and ranch irrigation survey (2013). 2012 Census of Agriculture, Vol. 3, Special Studies, Part 1 (AC12-SS-1). Washington, DC: USDA National Agricultural Statistics Service.

USDA-NASS. (2018). 2018 Irrigation and water management survey. 2017 Census of Agriculture, Vol. 3, Special Studies, Part 1 (AC-17-SS-1). Issued November 2019. Washington, DC: USDA National Agricultural Statistics Service.

van Donk, S. J., Petersen, J. L., \& Davison, D. R. (2012). Effect of amount and timing of subsurface drip irrigation on corn yield. Irrig. Sci., 31(4), 599-609. https://doi.org/10.1007/s00271-0120334-4

Wright, D., Feibert, E., Reitz, S., Shock, C., \& Waite-Cusic, J. (2018). Field evidence supporting conventional onion curing practices as a strategy to mitigate Escherichia coli contamination from irrigation water. J. Food Prot., 81(3), 369-376. https://doi.org/10.4315/0362-028x.jfp-17-231

Zaccaria, D., Carrillo-Cobo, M. T., Montazar, A., Putnam, D. H., \& Bali, K. (2017). Assessing the viability of subsurface drip irrigation for resource-efficient alfalfa production in central and southern California. Water, 9(11), 837.

https://doi.org/10.3390/w9110837

Zhang, H., Wang, D., Ayars, J. E., \& Phene, C. J. (2017). Biophysical response of young pomegranate trees to surface and subsurface drip irrigation and deficit irrigation. Irrig. Sci., 35(5), 425-435. https://doi.org/10.1007/s00271-017-0551-y

Zhu-Barker, X., Easter, M., Swan, A., Carlson, M., Thompson, L., Horwath, W. R., ... Steenwerth, K. L. (2019). Soil management practices to mitigate nitrous oxide emissions and inform emission factors in arid irrigated specialty crop systems. Soil Syst., 3(4), 76. https://doi.org/10.3390/soilsystems3040076

Zilverberg, C. J., Allen, V. G., Brown, C. P., Green, P., Johnson, P., $\&$ Weinheimer, J. (2012). Integrating cotton and beef production in the Texas Southern High Plains: II. Fossil fuel use. Agron. J., 104(6), 1643-1651. https://doi.org/10.2134/agronj2012.0119

Zilverberg, C. J., Philip Brown, C., Green, P., Galyean, M. L., \& Allen, V. G. (2014). Integrated crop-livestock systems in the Texas High Plains: Productivity and water use. Agron. J., 106(3), 831-843. https://doi.org/10.2134/agronj2013.0448

Zúñiga-Espinoza, C, Khot, L. R., Jacoby, P., \& Sankaran, S. (2016). Remote sensing based water-use efficiency evaluation in subsurface irrigated wine grape vines. Proc. SPIE, 9866, article 98660O. https://doi.org/10.1117/12.2228791

Zúñiga-Espinoza, C., Khot, L. R., Sankaran, S., \& Jacoby, P. W. (2017). High-resolution multispectral and thermal remote sensing-based water stress assessment in subsurface-irrigated grapevines. Remote Sensing, 9(9), 961-976. https://doi.org/10.3390/rs9090961

Zúñiga-Espinoza, C., Rathnayake, A. P., Chakraborty, M., Sankaran, S., Jacoby, P., \& Khot, L. R. (2018). Applicability of time-of-flight-based ground and multispectral aerial imaging for grapevine canopy vigour monitoring under direct root-zone deficit irrigation. Intl. J. Remote Sens., 39(23), 8818-8836. https://doi.org/10.1080/01431161.2018.1500047 